\title{
OPTIMIZING MICRONUTRIENT INTAKE OF LACTATING WOMEN IN KWAZULU-NATAL, SOUTH AFRICA, THROUGH INCREASED WILD EDIBLE PLANT CONSUMPTION
}

\author{
A Thesis \\ Presented to the Faculty of \\ California Polytechnic State University, \\ San Luis Obispo \\ In Partial Fulfillment \\ of the Requirements for the Degree \\ Master of Science in Agriculture, \\ Food Science and Nutrition Specialization
}

By

Kerry Pearson

June 2011 
(C)2011

Kerry Pearson

ALL RIGHTS RESERVED 


\section{COMMITTEE MEMBERSHIP}

TITLE:

OPTIMIZING MICRONUTRIENT INTAKE OF

LACTATING WOMEN IN KWAZULU-NATAL, SOUTH AFRICA, THROUGH INCREASED WILD

EDIBLE PLANT CONSUMPTION
AUTHOR:
Kerry Pearson

DATE SUBMITTED: June 2011

COMMITTEE CHAIR: Peggy Papathakis, Ph.D. Food Science and Nutrition

COMMITTEE MEMBER： Lisa Nicholson, Ph.D. Food Science and Nutrition

COMMITTEE MEMBER: Dawn Neill, Ph.D. Social Sciences 


\begin{abstract}
OPTIMIZING MICRONUTRIENT INTAKE OF LACTATING WOMEN IN

KWAZULU-NATAL, SOUTH AFRICA, THROUGH INCREASED WILD EDIBLE

PLANT CONSUMPTION
\end{abstract}

Kerry Pearson

Micronutrient consumption in KwaZulu-Natal, South Africa, is insufficient to meet the needs of lactating women. Inadequate intake negatively impacts the health of both the mother and infant. Increasing consumption of wild edible plants has been recommended to combat these deficiencies, but information has not yet been provided on which types of wild plants should be eaten or in what quantity. The objective of this study was to determine the optimal mixture of wild edible plants that needs to be consumed to meet the micronutrient needs of lactating women in rural KwaZulu-Natal, South Africa. This was done by creating optimization models using linear programming. Components of these models included identifying gaps between current micronutrient intake and recommended intake levels and the creation of composite nutrient profiles for groups of wild edible plants available in KwaZulu-Natal. One model calculated the optimum amount of wild edible plants that would need to be consumed in addition to the current diet to meet micronutrient recommendations. A second semi-isocaloric model calculated the optimum amount of wild edible plants that would need to be consumed if half the additional calories would replace an equivalent number of calories of the main staple food, maize. A combination of $250 \mathrm{~g}$ leafy vegetables and $349 \mathrm{~g}$ fruit, replacing $54 \mathrm{~g}$ 
of maize meal, was determined to be the best model. This mixture will meet the micronutrient needs of $50 \%$ of lactating women and would add only 192 calories to the diet. The same blend will meet the needs of $75 \%$ of women for all nutrients except calcium, zinc, thiamin, and riboflavin. It is hoped that increased use of wild plants will also increase physical activity and make the consumption of high quality animal products more economically feasible. Understanding forces that have brought about current dietary patterns in this population and working in tandem with other nutrition intervention programs will be the best way to successfully implement these goals. More complete information is needed on the nutrient profiles of wild edible plants in South Africa and on how anti-nutrients in these plants effects bioavailability of nutrients and the health of the consumer. Despite these limitations, it is clear that a reasonable increase in wild edible plant consumption can have a tremendous positive impact on micronutrient consumption of lactating women in KwaZulu-Natal, South Africa. 


\section{ACKNOWLEDGEMENTS}

Much thanks to my graduate committee, who supported me in all my crazy ideas, but were never afraid to tell me I was wrong. And a huge thanks to my parents for feeding me and letting me live at home. I couldn't have done it without you. 


\section{TABLE OF CONTENTS}

Page

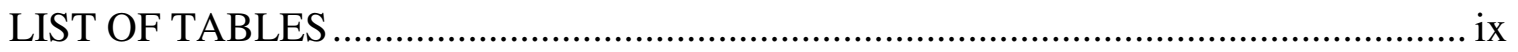

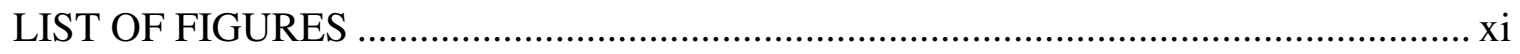

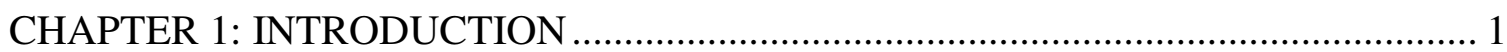

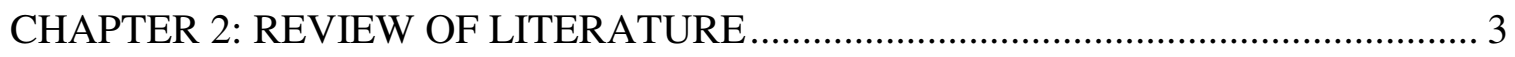

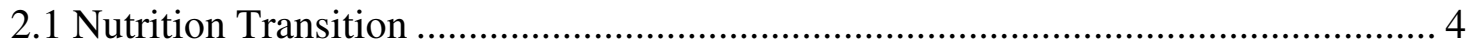

2.2 Diet Related Health Problems in South Africa .................................................... 12

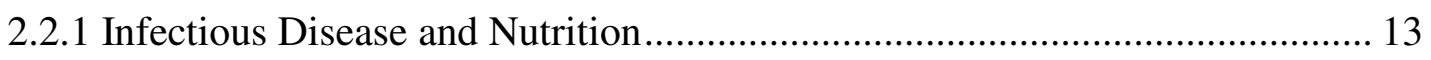

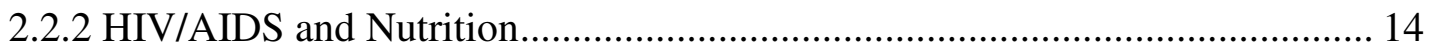

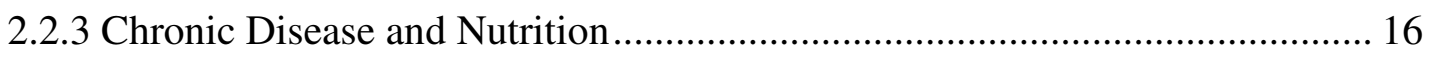

2.3 Intervention Programs.................................................................................. 18

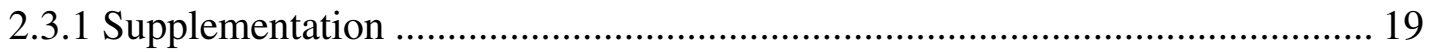

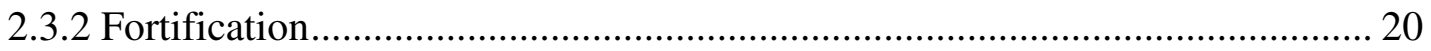

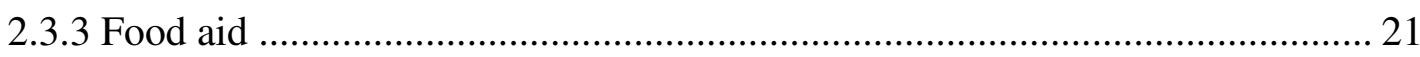

2.3.4 Home and community gardens .................................................................... 22

2.4 Consumption of Wild Edible Plants .................................................................. 23

2.4.1 General use of wild edible plants .............................................................. 24

2.4.2 Wild edible plants in KwaZulu-Natal, South Africa......................................... 26

2.4.3 Reasons for declining consumption ............................................................... 29

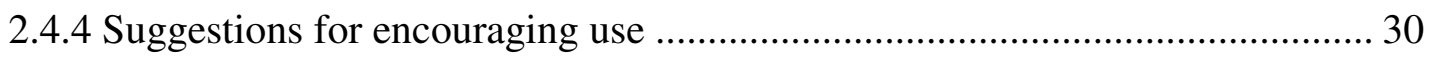

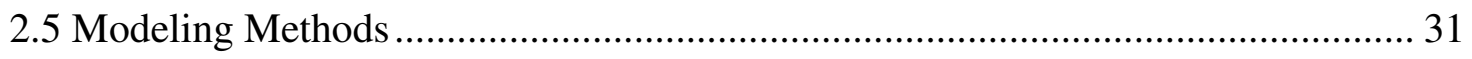

2.5.1 Dietary Assessment ................................................................................... 32

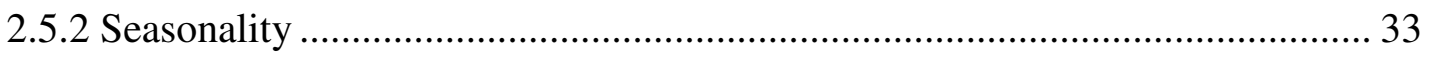

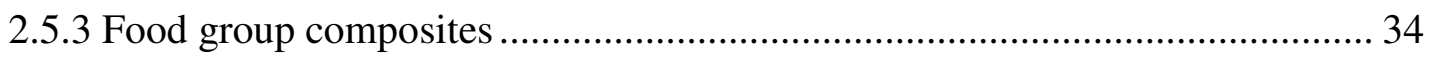

2.5.4 Linear programming ................................................................................. 35

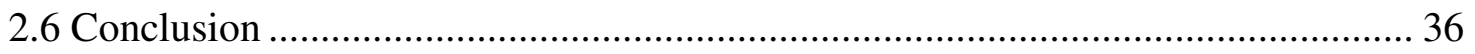

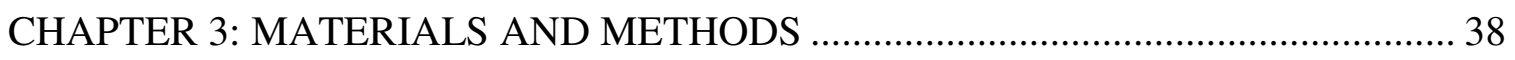

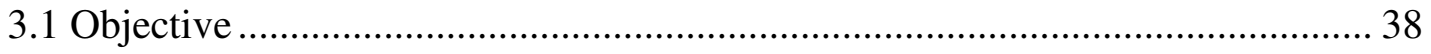

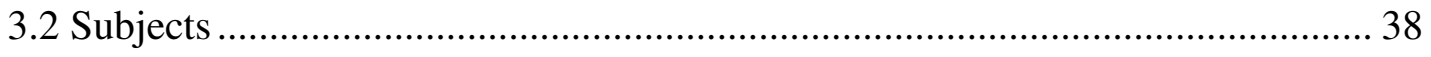




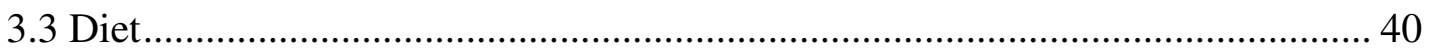

3.4 Nutrient profiles of wild edible plants ..................................................... 42

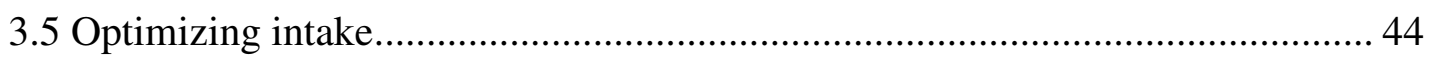

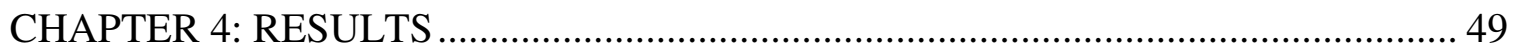

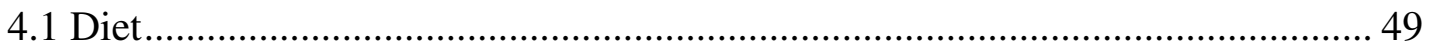

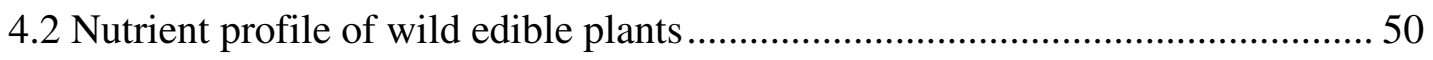

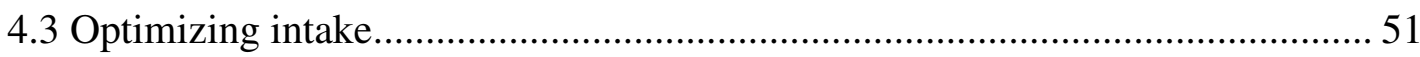

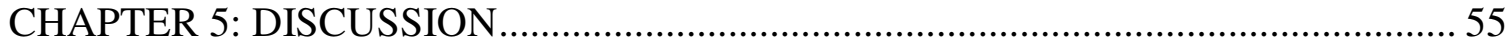

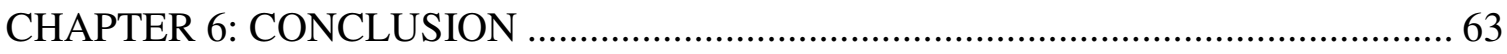

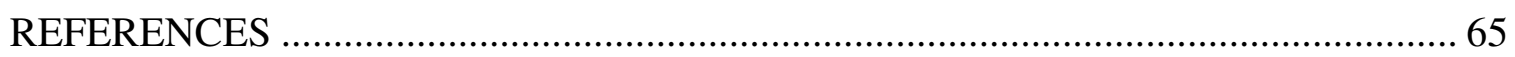

Appendix A: The Nutrition Transition in KwaZulu-Natal, South Africa....................... 77

Appendix B: Wild Fruits and Vegetables of KwaZulu-Natal, South Africa ................. 126

Appendix C: Nutrient Profiles of Wild Edible Plants................................................ 140 


\section{LIST OF TABLES}

Page

Table 2-1. Summary of nutrition transitions and influencing factors in

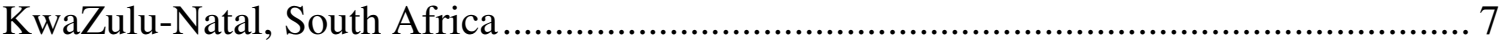

Table 2-2. Comparison of nutrient composition per 100g of cooked wild and

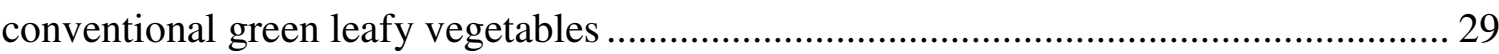

Table 2-3. Ideas for supporting indigenous food systems ......................................... 30

Table 3-1. Baseline characteristics of breastfeeding mothers ...................................... 39

Table 3-2. Average pre-fortification intakes of fortified nutrients for all women $(n=142)$ compared to intakes of the sub-sample with records both before and after fortification $(n=34)$

Table 3-3. Average difference in fortified nutrient intake following fortification of maize and wheat products

Table 3-4. Values used in different linear programming models representing the amount of each nutrient provided per unit food (per gram, per calorie, or per calorie minus $1 / 2$ calorie maize meal)

Table 4-1. Summary of adjusted first quartile, median, and third quartile nutrient intake, Estimated Average Requirements, and the percentage of women consuming less than the EAR

Table 4-2. The amount of nutrients needed to meet the needs of $50 \%$ and $75 \%$ of lactating women in KwaZulu-Natal 50

Table 4-3. Composite nutrient profiles of wild edible plant food groups per $100 \mathrm{~g}$ 50

Table 4-4. Optimum blends of wild edible plant food groups that need to be consumed to meet the nutrient needs of $50 \%$ and $75 \%$ of lactating women while minimizing total grams or calories provided

Table 4-5. Optimal food group composition of wild edible plants that need to be consumed to meet the nutrient needs of $50 \%$ and $75 \%$ of lactating women when using a semi-isocaloric model in which half the calories provided by the wild edible plants replace an equivalent number of calories of fortified maize meal 
Table 4-6. Nutrient composition of optimal blend of wild edible plants to meet the needs of $50 \%$ of lactating women using a semi-isocaloric model, where half of additional calories are replacing the nutrients in an equivalent amount of maize meal, and the potential impact on total diet.

Table 5-1. Comparison of the composite nutrient values for leafy green vegetables for wild edible plants used in this study and the values created by the USDA 


\section{LIST OF FIGURES}

Figure 2-1. Impact of undernutrition through the lifecycle .......................................... 14

Figure 2-2. Causal web for risk factors and diseases events implemented in the

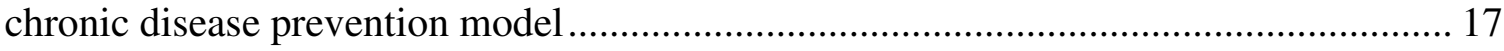

Figure 3-1. Explanation of the components involved in the optimization function ......... 45

Figure 4-1. Median percentage of the Estimated Average Requirement of micronutrients currently consumed and predicted improvement if $250 \mathrm{~g}$ wild leafy vegetable and $349 \mathrm{~g}$ fruit are eaten, replacing $54 \mathrm{~g}$ of maize meal................................. 54 


\section{CHAPTER 1}

\section{INTRODUCTION}

South Africa, like many developing countries, is currently facing a double burden of disease stemming from poor nutrition (Faber and Wenhold, 2007). Insufficient intake of nutrients, particularly protein, vitamins $\mathrm{A}, \mathrm{C}$, and $\mathrm{E}$, the $\mathrm{B}$ vitamins, iron, zinc, and selenium, negatively impact the immune system, increasing the frequency and severity of infectious diseases (Marcos et al., 2003). At the same time, diets high in saturated fat and low in fresh fruits and vegetables, along with other risk factors such as low physical activity, are bringing about high rates of obesity and associated chronic disease (Peltzer, 2009). Interventions are needed to help correct some of these nutrient inadequacies and improve health.

The nutritional status of lactating women is of particular importance. During lactation, the maternal requirement for protein, vitamins $\mathrm{A}, \mathrm{B}_{6}, \mathrm{C}$, riboflavin, zinc, and iodine are between 40-90\% higher than pre-pregnancy, while the requirements for thiamine, niacin, folate, vitamin E, and selenium are about 25\% higher (Picciano, 2003). A mother's nutritional status also affects the concentrations of certain micronutrients in breast milk, notably the B vitamins, vitamin A, and iodine, which can have long term impacts on her child's health (Jones et al., 2010).

Adequate consumption of fruits and vegetables is known to improve nutritional status, decrease the risk of certain chronic diseases, and improve immune response (Schneider et al., 2007; WHO/FAO, 2003). Consumption of fruits and vegetables in South Africa, unfortunately, is very low, most likely because of low availability and 
widespread poverty (Schneider et al., 2007). The government of South Africa, in cooperation with international agencies, has proposed a plan to improve micronutrient consumption of its people by encouraging increased use of wild edible plants. Wild plants have the advantage of being easy to grow, resistant to pests and diseases, locally familiar, and freely available (Aphane et al., 2002). Research has been undertaken to identify available wild species and current practices involving them, but no efforts to date have been made to determine the amounts and types of wild edible plants that need to be eaten to optimize micronutrient intakes. This step is essential in the planning of an effective nutrition intervention. 


\section{CHAPTER 2}

\section{REVIEW OF LITERATURE}

Several interacting forces, such as physical, social, and economic environments, technology, and culture, work together to shape human food use and nutritional status (Goodman et al., 2000). Changes in these forces over time lead to phenomena known as nutrition transitions. Nutrition transitions are characterized by large shifts in diet and activity patterns, reflected by nutritional outcomes (Popkin, 2006). While all populations are expected to experience these transitions, they do not necessarily do so within the same periods of history or at the same rate (Popkin, 1999). Many lower- and middleincome countries are currently transitioning at a very rapid rate from a period of receding famine, characterized by high rates of infectious disease, to a period dominated by nutrition-related noncommunicable disease as subsistence economies shift to modern industrialized ones (Popkin, 2004). Consequently, the populations of many of these countries are currently burdened with high rates of both undernutrition and overnutrition. South Africa is no exception. As of 2004, 23.4\% of South African deaths were caused by infectious and parasitic diseases, with an additional $13.9 \%$ of deaths being caused by diseases of the circulatory system (SSA, 2006). Nutrition plays an important role in both infectious and noncommunicable diseases. Multiple intervention programs have been devised to help overcome undernutrition in South Africa, including supplementation, fortification, food aid, and encouragement of home and community gardens.

Increasing consumption of wild edible plants is also being considered as a practical and sustainable approach to preventing malnutrition (Aphane et al., 2002). Wild 
edible plants continue to be consumed by many populations, but knowledge and use of these plants is decreasing. In order to create a successful intervention utilizing these foods, information is needed on how much and which types of foods should be encouraged to optimize nutritional intake. This can be done by creating a population specific optimization model using linear programming. As components of this model, gaps between current micronutrient intake and recommended levels will need to be determined and composite nutrient profiles for groups of wild edible plants created. This model, along with understanding reasons for current food choices, nutritional impacts of common diseases, and other available intervention programs, will allow for a successful plan to be devised.

\subsection{Nutrition Transition}

Five general stages of nutrition transition have been identified by Popkin (2006). The first is typified by hunter-gather societies in which diet and nutritional status generally support excellent health. The second is typified by a period of famine and undernutrition following introduction of modern agriculture and dependence on cereal crops. Third, income increases and famine recedes while many nutritional deficiencies disappear. In the fourth phase, overnutrition and decreased physical activity lead to the emergence of degenerative diseases. The final phase reverses the negative tendencies of overnutrition and inactivity in the proceeding period through behavioral change.

South Africa is currently in the midst of transitioning from a period of receding famine, characterized by undernutrition and high rates of infectious disease, to a period of overnutrition and degenerative disease. Twenty three percent of the population of 
KwaZulu-Natal has inadequate access to food (SSA, 2009) and nationally $19.3 \%$ of children are stunted, an indicator of long-term undernutrition (Steyn et al., 2005). At the same time, $21 \%$ of adolescents are overweight or obese (Kimani-Murage et al., 2010), with rates rising to $31.8 \%$ among black women (Charlton et al., 2004). Comparison of national food balance sheets from 1962 and 2001 indicate that per capita food and energy availability has increased. During that period, typical dietary macronutrient composition shifted from $21.2 \%$ fat, $68.3 \%$ carbohydrate, and $10.5 \%$ protein to a more Western pattern of $24.3 \%$ fat, $65.4 \%$ carbohydrate, and $10.3 \%$ protein that is known to increase risk of chronic disease (Zingoni et al., 2009).

It has been proposed that a return to traditional foods and food habits will improve health and help combat the growing noncommunicable disease epidemic (Raschke and Cheema, 2007). Because food behaviors are shaped by many different factors, such as physical environment, social and economic environments, technology, and culture, these factors need to be taken into account when attempting to bring about behavior change. Table 2-1 summarizes the nutrition transition and factors influencing the diet and health of the people of KwaZulu-Natal, South Africa, from the time of the San hunter-gatherers, to the Bantu farmers, and on to the establishment of the Zulu Kingdom and period of European colonization, followed by apartheid and modern South Africa. A more complete explanation of the nutrition transition in KwaZulu-Natal is found in Appendix A.

Currently known as the "garden province" of South Africa (Prins, 2009), KwaZulu-Natal is located in the eastern portion of the country, bordered by Swaziland and Mozambique to the north, the Indian Ocean to the east, Lesotho to the south, with the 
Drakensberg mountain range forming the western border (Prins, 2009). The geology, topography, and climate are remarkably varied within the province, with the land rising from relatively flat coastal plains in the east, up a series of plateau, to culminate with the Drakensberg. The majority of rainfall is received in summer (December through March), with great variation in both precipitation and temperature in the mountainous regions, while the coastal regions experience a modifying effect on climate thanks to the offshore Mozambique current and receives rain year round. Indigenous forests occur throughout the high rainfall areas. These forest regions support a high proportion of South Africa's plant and wildlife diversity (Eeley et al., 1999). Between forest bands lies savannah grassland (Prins, 2009). The population living in this area is predominantly of Zulu ethnic origin and is characterized by high rates of HIV infection, unemployment, poor access to clean water, and a high infant mortality rate (Hosegood, 2001).

Environmental, social, and economic conditions have been the main driving forces behind the nutrition transitions in KwaZulu-Natal. The hunter-gatherer lifestyle of the San, who were the first known inhabitants of South Africa, provided them with a diet rich in variety and adequate in nutrients, contributing to excellent health (Truswell, 1977). Low population density and the ability to move about in search of food allowed this diverse diet to be maintained in spite of environmental instabilities (Bousman, 2005). Close social ties helped ensure all members of the band were cared for (Dewar et al., 2006; Schapera, 1930).

The arrival of agriculture around 1500 years ago with the Bantu farmers, or Nguni, provided a more reliable food source, allowing greater population growth and a more stationary lifestyle. Diet and health remained excellent, thanks to greater reliability 
Table 2-1. Summary of nutrition transitions and influencing factors in KwaZulu-Natal, South Africa

\begin{tabular}{|c|c|c|c|c|c|c|}
\hline & \multicolumn{2}{|c|}{ Collecting food } & \multicolumn{2}{|r|}{ Famine } & \multicolumn{2}{|c|}{$\begin{array}{c}\text { Receding famine / } \\
\text { Degenerative disease }\end{array}$} \\
\hline & San hunter-gatherers & Bantu farmers & Zulu Kingdom & Colonization & Apartheid & Post-apartheid \\
\hline Diet & $\begin{array}{l}\text { Great variety, plants } \\
\text { provide majority of } \\
\text { calories }\end{array}$ & $\begin{array}{l}\text { Sorghum and millet } \\
\text { staples, later maize; } \\
\text { cultivated and } \\
\text { gathered vegetables; } \\
\text { sour milk; } \\
\text { domesticated and } \\
\text { hunted meat }\end{array}$ & $\begin{array}{l}\text { Growing } \\
\text { dependence on } \\
\text { maize; preference } \\
\text { for meat; grass and } \\
\text { hardy wild plants } \\
\text { eaten during } \\
\text { famine }\end{array}$ & $\begin{array}{l}\text { Low quality and } \\
\text { monotonous; } \\
\text { dependence on maize }\end{array}$ & $\begin{array}{l}\text { Dependence on } \\
\text { cheap imported } \\
\text { foods; small } \\
\text { quantities of } \\
\text { vegetables, milk, or } \\
\text { meat }\end{array}$ & $\begin{array}{l}\text { Transition to } \\
\text { westernized high fat } \\
\text { diet; dependence on } \\
\text { maize meal, sugar, } \\
\text { tea, and wheat } \\
\text { bread; low variety }\end{array}$ \\
\hline Health & Generally excellent & Generally excellent & $\begin{array}{l}\text { Widespread } \\
\text { famine, } \\
\text { malnutrition, and } \\
\text { disease }\end{array}$ & $\begin{array}{l}\text { Common famine and } \\
\text { malnutrition; high } \\
\text { childhood mortality; } \\
\text { infectious disease }\end{array}$ & $\begin{array}{l}\text { Malnutrition and } \\
\text { starvation; infectious } \\
\text { disease; } 50 \% \\
\text { mortality by age } 5\end{array}$ & $\begin{array}{l}\text { High rates of } \\
\text { infectious and } \\
\text { chronic disease, } \\
\text { HIV/AIDS; stunting } \\
\text { prevalent in } \\
\text { children, overweight } \\
\text { and obesity in adults }\end{array}$ \\
\hline $\begin{array}{l}\text { Physical } \\
\text { Environment }\end{array}$ & $\begin{array}{l}\text { Frequent drought, } \\
\text { adapted by } \\
\text { increasing territory/ } \\
\text { decreasing } \\
\text { population density }\end{array}$ & $\begin{array}{l}\text { Frequent drought } \\
\text { and locust } \\
\text { infestations }\end{array}$ & Severe drought & $\begin{array}{l}\text { Prolonged drought, } \\
\text { stock disease, locust } \\
\text { infestations; } \\
\text { environmental } \\
\text { degradation in } \\
\text { overcrowded reserves }\end{array}$ & $\begin{array}{l}17 \% \text { of food needs } \\
\text { produced in } \\
\text { bantustans; } \\
\text { environmental } \\
\text { degradation from } \\
\text { overpopulation }\end{array}$ & $\begin{array}{l}\text { Improved access to } \\
\text { housing, electricity, } \\
\text { and clean water; } \\
\text { failed land reforms; } \\
\text { water and air } \\
\text { pollution }\end{array}$ \\
\hline $\begin{array}{l}\text { Social } \\
\text { Environment }\end{array}$ & $\begin{array}{l}\text { Nuclear families in } \\
\text { small bands with } \\
\text { strong social ties }\end{array}$ & $\begin{array}{l}\text { Settlements of 50- } \\
400 ; \text { strong social } \\
\text { bonds; hierarchical }\end{array}$ & $\begin{array}{l}\text { Brutal warfare; } \\
\text { establishment of } \\
\text { central authority; } \\
\text { age based } \\
\text { regiments; } \\
\text { widening roles of } \\
\text { women }\end{array}$ & $\begin{array}{l}\text { Lower rates of } \\
\text { marriage and greater } \\
\text { rates of } \\
\text { abandonment; } \\
\text { breakdown in respect } \\
\text { for elders }\end{array}$ & $\begin{array}{l}\text { Segregation laws; } \\
\text { men often away from } \\
\text { families; urban } \\
\text { migration; common } \\
\text { cohabitation and } \\
\text { pregnancy outside of } \\
\text { marriage; domestic } \\
\text { violence and gang } \\
\text { activity }\end{array}$ & $\begin{array}{l}\text { Legal equality; } \\
\text { continued violence } \\
\text { and crime; } \\
\text { increasing number } \\
\text { of female headed } \\
\text { households; } \\
\text { HIV/AIDS stigma; } \\
\text { helplessness about } \\
\text { future }\end{array}$ \\
\hline
\end{tabular}


Table 2-1. Continued

\begin{tabular}{|c|c|c|c|c|c|c|}
\hline & \multicolumn{2}{|c|}{ Collecting food } & \multicolumn{2}{|r|}{ Famine } & \multicolumn{2}{|c|}{$\begin{array}{c}\text { Receding famine / } \\
\text { Degenerative disease }\end{array}$} \\
\hline & San hunter-gathers & Bantu farmers & Zulu Kingdom & Colonization & Apartheid & Post-apartheid \\
\hline $\begin{array}{l}\text { Economic } \\
\text { Environment }\end{array}$ & $\begin{array}{l}\text { Philosophy of } \\
\text { limited wants; all } \\
\text { members worked } \\
\text { together to provide } \\
\text { food }\end{array}$ & $\begin{array}{l}\text { Wealth measured in } \\
\text { cattle; poor people } \\
\text { worked as clients to } \\
\text { the wealthy }\end{array}$ & $\begin{array}{l}\text { More cattle, grain, } \\
\text { and service of } \\
\text { mature men } \\
\text { demanded by king, } \\
\text { responsibility for } \\
\text { agriculture and } \\
\text { homestead } \\
\text { management on } \\
\text { shoulders of } \\
\text { women }\end{array}$ & $\begin{array}{l}\text { Forced poverty } \\
\text { through taxes and } \\
\text { land restriction; } \\
\text { migrant labor begins } \\
\text { to be common }\end{array}$ & $\begin{array}{l}\text { Two thirds of } \\
\text { incomes below } \\
\text { Minimum Living } \\
\text { Level }\end{array}$ & $\begin{array}{l}\text { High unemployment } \\
\text { and poverty; } \\
\text { government grants } \\
\text { for pensioners, poor } \\
\text { children, and } \\
\text { disabled; insufficient } \\
\text { education to } \\
\text { compete in global } \\
\text { economy }\end{array}$ \\
\hline Technology & $\begin{array}{l}\text { Digging sticks, bows } \\
\text { and poisoned } \\
\text { arrows; food cooked } \\
\text { in wooden or clay } \\
\text { bowls; limited } \\
\text { storage }\end{array}$ & $\begin{array}{l}\text { Iron tools and } \\
\text { weapons; swidden } \\
\text { agriculture; storage } \\
\text { pits for long- and } \\
\text { short-term use }\end{array}$ & $\begin{array}{l}\text { Focused on } \\
\text { warfare }\end{array}$ & $\begin{array}{l}\text { Ox-drawn plow; } \\
\text { settler plantations } \\
\text { eventually replace } \\
\text { African agriculture } \\
\text { with new scientific } \\
\text { methods; Africans } \\
\text { restricted to unskilled } \\
\text { labor positions }\end{array}$ & $\begin{array}{l}\text { Few modern } \\
\text { conveniences; } \\
\text { agricultural } \\
\text { betterment programs } \\
\text { resisted }\end{array}$ & $\begin{array}{l}\text { Improved access to } \\
\text { modern technology; } \\
\text { paraffin or wood } \\
\text { still used by many } \\
\text { households for } \\
\text { cooking; increased } \\
\text { assistance for } \\
\text { improved agriculture }\end{array}$ \\
\hline Culture & $\begin{array}{l}\text { Veneration of } \\
\text { heavenly bodies and } \\
\text { rain; celebrations of } \\
\text { birth, puberty, and } \\
\text { marriage }\end{array}$ & $\begin{array}{l}\text { Respect for elders; } \\
\text { veneration of } \\
\text { ancestors; all natural } \\
\text { events caused by } \\
\text { human action }\end{array}$ & Dominated by king & $\begin{array}{l}\text { Retained strong } \\
\text { social ties; } \\
\text { hospitality; } \\
\text { introduction of } \\
\text { Christianity }\end{array}$ & $\begin{array}{l}\text { Culture of hospitality } \\
\text { continued under } \\
\text { great pressure from } \\
\text { poverty; } \\
\text { establishment of } \\
\text { African Christian } \\
\text { churches to help } \\
\text { reconstruct sense of } \\
\text { community }\end{array}$ & $\begin{array}{l}\text { Division between } \\
\text { desire to return to } \\
\text { traditional values } \\
\text { and desire to break } \\
\text { from past }\end{array}$ \\
\hline
\end{tabular}


of food and sustained variety from both agriculture and continued use of collected foods and hunting (Thompson, 2000). Strong family units and social ties persisted in ensuring all members of the community were cared for (Thompson, 2000). As population levels grew, cereal crops, especially maize, became increasingly relied upon to meet the food needs of the people (McCann, 2001). Consequently, dietary variety decreased and nutrient adequacy suffered (Brenton and Paine, 2007). These grain crops were also more susceptible to environmental stressors, such as drought and locust infestations, leading to frequent famine (McCann, 2001). During periods of drought and famine, the Nguni people subsisted largely by foraging, which may have led to a negative perception that persists today of wild foods being famine foods (Ballard, 1986b).

This period of famine continued as violence and bloodshed associated with the establishment of the Zulu Kingdom at the beginning of the nineteenth century worsened problems of starvation. Establishment of central authority shifted focus somewhat away from food production towards pursuits of honor and power (Deflem, 1999). Family structure was weakened and social inequalities grew (Deflem, 1999; Hanretta, 1998).

Drought, locust infestations, and cattle plagues, along with taxes and land restrictions, effectively forced the African people into poverty after the British seized control in the mid-nineteenth century (Ballard, 1986a). Family structure continued to deteriorate as children gained opportunity and necessity to see to their own needs, independent of the family (Redding, 2006). The migrant labor system also tore families apart and often placed the entire burden of agricultural production on the shoulders of women, who had access to only small plots of poor ground in native land reserves. The 
frequent famine during this time contributed to over one-fifth of children on reservations dying within their first year (Thompson, 2000).

These conditions intensified under apartheid, South Africa's official policy of segregation established in 1948 (Thompson, 2000). A large portion of the population during this period lived with chronic malnutrition, which was easily pushed over to frank starvation during periods of severe drought. Undernutrition was made worse by disrupted family structure. Children had a greater chance of being undernourished if they had unmarried parents and if they were looked after by someone other than their mother (Wisner, 1989). Unable to live off subsistence agriculture, people grew dependent on cheap imported foods such as white bread, white maize, and white sugar (Mager, 2004). Typical diets consisted of over 50\% maize and included relatively small quantities of green and yellow vegetables, milk, meat, and fish. Diets tended to be worse among those who lived most of their lives in a rural setting (Abramson et al., 1960). An estimated 5\% of rural children suffered from marasmus, or severe energy deficiency, and 10-15\% from Kwashiorkor, or severe protein deficiency. Mortality by age five, considered an indicator of the overall nutritional situation, was around $50 \%$ in the bantustans, where black Africans were forced to live when not employed elsewhere. Pellagra from niacin deficiency, rickets from vitamin D deficiency, scurvy from vitamin C deficiency, and vitamin A deficiency blindness were all common (Wisner, 1989).

Poor nutrition also had a devastating effect on other aspects of health during apartheid. In a period when white South Africans experienced the diseases common to industrial nations and enjoyed some of the highest standards of health care in the world, their black counterparts suffered heavily from conditions common to developing 
countries, including pneumonia, tuberculosis, gastroenteritis, typhoid, typhus, measles, and rheumatic fever. There were also epidemics of cholera, polio, and bubonic plague. Mine workers often suffered from disabling injuries or contracted lung disease. Infant and childhood mortality rates were among the highest in Africa, predominantly due to inadequate nutrition. Official life expectancy rates, believed to be overestimates, were 51.2 years for men and 58.9 for women (Thompson, 2000).

The end of apartheid in 1994 has done little to change these situations. Poverty remains wide spread, undernutrition and infectious disease are common, and traditional family structure is degraded (Kaarsholm, 2005). The famine phase of the nutrition transition appears to have ended, but has been replaced with the combined effects of the receding famine and degenerative disease phases. South Africa is described as suffering from a quadruple burden of disease: infectious disease associated with poverty and undernutrition, chronic disease associated with overnutrition, the HIV/AIDS epidemic, and injury-related deaths (Faber and Wenhold, 2007). Twenty three percent of the population of KwaZulu-Natal has inadequate access to food (SSA, 2009). The most commonly consumed foods are maize porridge, white sugar, tea, wheat and white bread (Steyn et al., 2003). The most commonly consumed vegetables are cabbage and, to a lesser extent, imifino, a blend of locally gathered wild leafy greens (Faber et al., 2001). Despite availability of these and other wild foods, indigenous vegetables are often despised and avoided as poor people's food (Faber et al., 2010). Low variety in the diet predisposes individuals to low micronutrient intakes. Intakes of vitamin A tend to be particularly low, affecting eye health and immune function. A large portion of the population also suffers from iron deficiency anemia. Stunting caused by chronic 
malnutrition is prevalent among children, while overweight and obesity are common among adults, particularly women (Faber et al., 2001). Many people desire to break with their traditional heritage and be seen as modern (Vincent, 2006), which encourages adoption of a high-fat westernized diet associated with chronic disease.

Access to modern conveniences has improved. Eighty four percent of households now have access to piped water, $76.4 \%$ are connected to an electric supply, only $6.3 \%$ have no toilet facility or use a bucket toilet, and 73\% have a cell phone (SSA, 2007; SSA, 2009). Efforts are also being made to assist black farmers to enhance productivity (Saunderson, 1995). Only when poverty is alleviated, families are strengthened, access to and affordability of healthful foods is improved, and awareness of nutritional issues is increased, can South Africa transition away from the current pattern of receding famine and degenerative disease and into the more healthful pattern of behavioral change.

\subsection{Diet Related Health Problems in South Africa}

The leading underlying natural causes of death in KwaZulu-Natal, as reported on death notification forms from 2003-2004, are tuberculosis (16\%), influenza and pneumonia $(7.2 \%)$, intestinal infectious disease $(5.1 \%)$, cerebrovascular disease $(5.1 \%)$, other forms of heart disease (3.8\%), and diabetes (3.3\%) (SSA, 2006). HIV and AIDS, which has a prevalence rate of $18 \%$ in the population and $40 \%$ among pregnant women (Ncama et al., 2008), is alternately estimated to be the leading cause of death in South Africa, accounting for as many as 34\% of female deaths in the year 2000 (Norman et al., 2010). Nutrition plays an important role in the development and/or treatment of each of 
these illnesses. They will be discussed in the broad categories of infectious disease, HIV/AIDS, and chronic disease.

\subsubsection{Infectious Disease and Nutrition}

Infectious diseases, such as tuberculosis, influenza, pneumonia, and intestinal diseases, are characteristically high in undernourished populations (Rice et al., 2000). Nutrition plays an essential role in proper functioning of the immune system. Poor nutrition can suppress immune function, thereby increasing risk of infection, which in turn brings about physiological changes that worsen nutritional status. Once infected with a pathogen, the weakened immune system is less capable of fighting off disease (Jones et al., 2010). Undernutrition tends to be complex, involving several deficient nutrients. Several nutrients individually have a crucial function in the immune response. These include vitamin A, beta-carotene, folic acid, vitamins $\mathrm{B}_{6}, \mathrm{~B}_{12}, \mathrm{C}, \mathrm{E}, \mathrm{D}$, riboflavin, iron, zinc, selenium, energy, lipids, and protein (Marcos et al., 2003). Fiber also plays an important role in supporting immune function by improving health of the intestinal tract, which acts as a physical barrier to infection (Bengmark, 2010).

Nutritional status is important for mothers both for the role it plays in their own health and immune function as well as the impact it has on their children, as can be seen in Figure 2-1. Poor vitamin A status has been identified with increased risk of maternal infections and mortality. It has been suggested that improved antioxidant intake may reduce maternal morbidity (Tomkins, 2001). The relationship between maternal nutrition and fetal growth is complex, but maternal protein-energy malnutrition (PEM) often results in low birthweight (LBW) infants (Jones et al., 2010). LBW infants suffer from reduced immune response and impaired immunocompetence that may persist for years 
(Chandra, 2002). Maternal nutrition status determines concentrations of some nutrients

in breast milk, specifically the B vitamins, vitamin A, and iodine (Jones et al., 2010).

Maternal deficiencies in these nutrients lead to infant deficiencies and impaired immune

function. Malnutrition during infancy can lead to permanent structural and functional

changes in the developing immune system (Jones et al., 2010). Combating maternal

malnutrition, then, can improve the health and well being of the entire population.

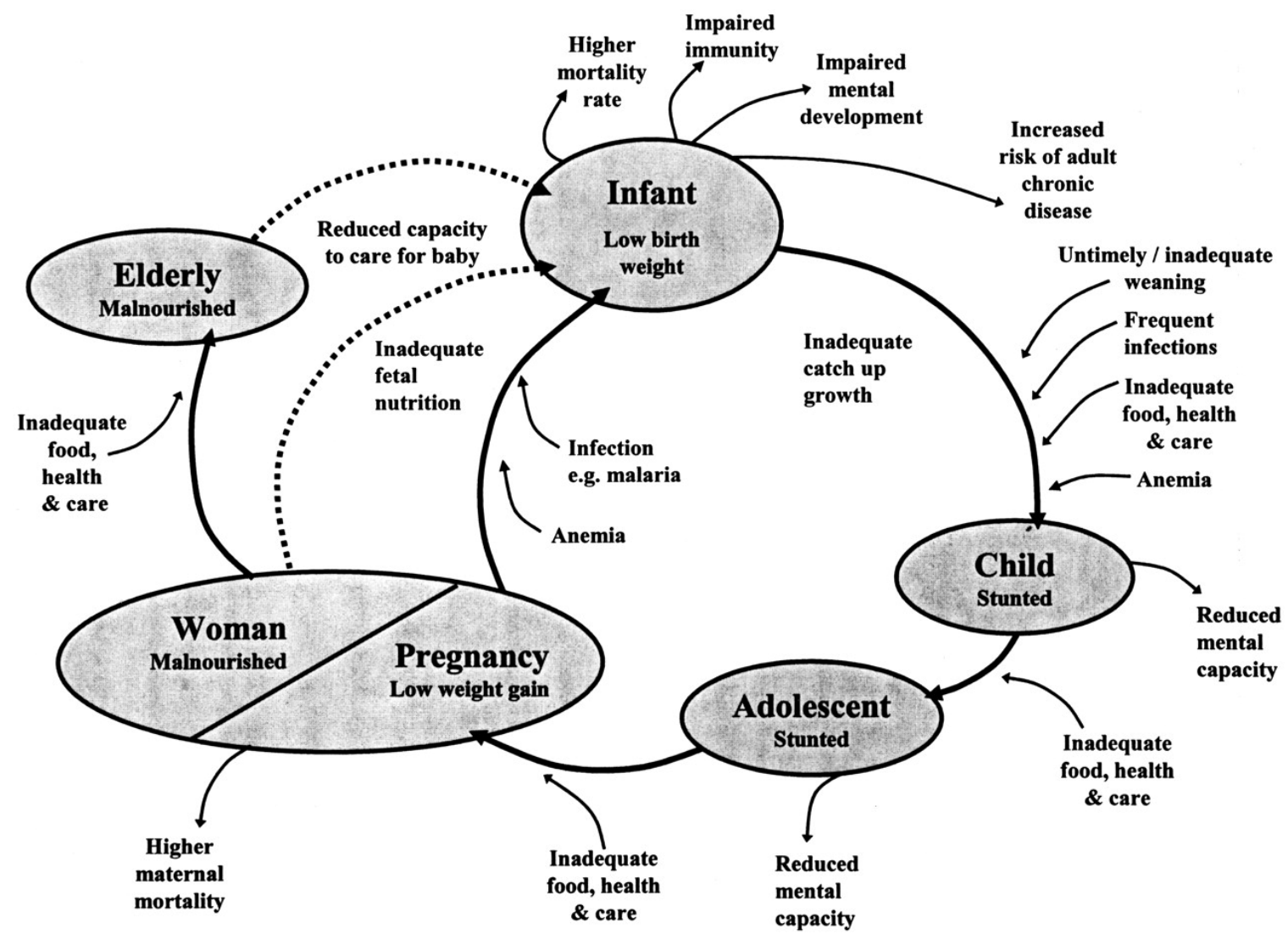

Figure 2-1. Impact of undernutrition through the lifecycle (Steketee, 2003)

\subsubsection{HIV/AIDS and Nutrition}

Human immunodeficiency virus (HIV) acts by destroying blood CD4+ T cells, which function as part of the immune system. HIV leads to acquired immune deficiency 
syndrome (AIDS) when the immune system becomes severely damaged (CDC, 2010). As the CD4+ T cells are reduced, HIV infected individuals become susceptible to opportunistic infections that the body is unable to effectively fight. Proper nutrition can slow progression of the disease and improve immune function (Suttajit, 2007). Weight loss is another severe consequence of HIV that can lead to death. HIV infection increases resting energy expenditure, leading to increased protein and energy needs (Ivers et al., 2009). The virus also directly alters absorption, storage, and utilization of nutrients. Malabsorption of lipids and carbohydrates is especially common. Impaired fat absorption affects absorption of fat-soluble vitamins, many of which are important in immune function (Semba and Tang, 1999).

To compound these problems, HIV decreases productivity, often resulting in decreased income and poverty, leading to a diet of inadequate quantity and quality to support health (Ivers et al., 2009). In children, advanced HIV infection often presents with clinical features indistinguishable from severe undernutrition (Beisel, 1996). A diet containing sufficient meat, fruits, and vegetables has been suggested for HIV infected individuals to help minimize weight loss and provide sufficient nutrients to support immune function (Vorster et al., 2004).

Breastfeeding women in South Africa with HIV have been found to have lower concentrations of serum albumin, prealbumin, folate, retinol, and hemoglobin than HIV negative lactating mothers (Friis and Koestel, 2001; Papathakis et al., 2007). They also tend to have greater rates of anemia and deficiencies in vitamin $\mathrm{B}_{12}$ and zinc. It is unclear if these differences occur specifically during lactation or in HIV in general (Papathakis et al., 2007). Adequate nutritional status also has an impact on vertical transmission of HIV 
from a mother to her child. The virus can be transmitted through the placenta, during birth, or through breastfeeding. Consequently, undernutrition may impair integrity of the epithelial lining of the placenta, lower genital tract, or breast, which may lead to higher rates of transmission. Impaired integrity of the infant's gastrointestinal tract can also increase risk of transmission through breast milk (Fawzi, 2000). Low plasma levels of vitamin A during pregnancy have been observed to be associated with higher risk of vertical transmission of HIV (Semba et al., 1994), but it is unclear if low levels of vitamin A are a causative factor or a marker of advanced disease, and therefore of increased rates of transmission (Fawzi, 2000).

HIV-infected individuals also manifest several metabolic abnormalities that contribute to higher rates of cardiovascular disease (CVD), making CVD an important cause of illness and death in this population (Lohse et al., 2007). These abnormalities include dyslipidemia and insulin resistance, changes in body composition such as loss of subcutaneous fat and accumulation of visceral fat, and inflammation (Grinspoon and Carr, 2005). Direct effects of the virus on the vascular system and toxic effects of antiretroviral drugs may also be contributing factors (Grinspoon et al., 2008).

\subsubsection{Chronic Disease and Nutrition}

Emphasis in developing countries on undernutrition in children and infectious

diseases has overshadowed growing problems with overnutrition related chronic diseases, such as heart disease, hypertension, and diabetes (Gokah and Gumpo, 2010). The majority of chronic diseases share several behavioral risk factors: a diet high in saturated fat and low in fresh fruits and vegetables, low physical activity, tobacco smoking, and excessive alcohol consumption (Peltzer, 2009). Being malnourished as a child is also a 
risk factor for developing chronic disease later in life. Undernourished infants and children undergo metabolic and physiological adaptations in response to nutrient-poor environments to improve their ability to survive. These adaptations can lead to distorted physiological responses if environment changes, increasing the risk of glucose intolerance, hypertension, obesity, and cardiovascular disease later in life (Gokah and Gumpo, 2010).

The progression of chronic disease from nutrition and lifestyle related risk factors to actual disease is summarized in Figure 2-2. In general, diets high in fat and low in fiber and micronutrients, in association with insufficient physical activity, can lead to overweight and obesity. Overweight and obesity are associated with hypertension, hypercholesterolemia, and impaired glucose tolerance. These conditions can eventually lead to various forms of heart disease and diabetes (Cecchini et al., 2010). Specific

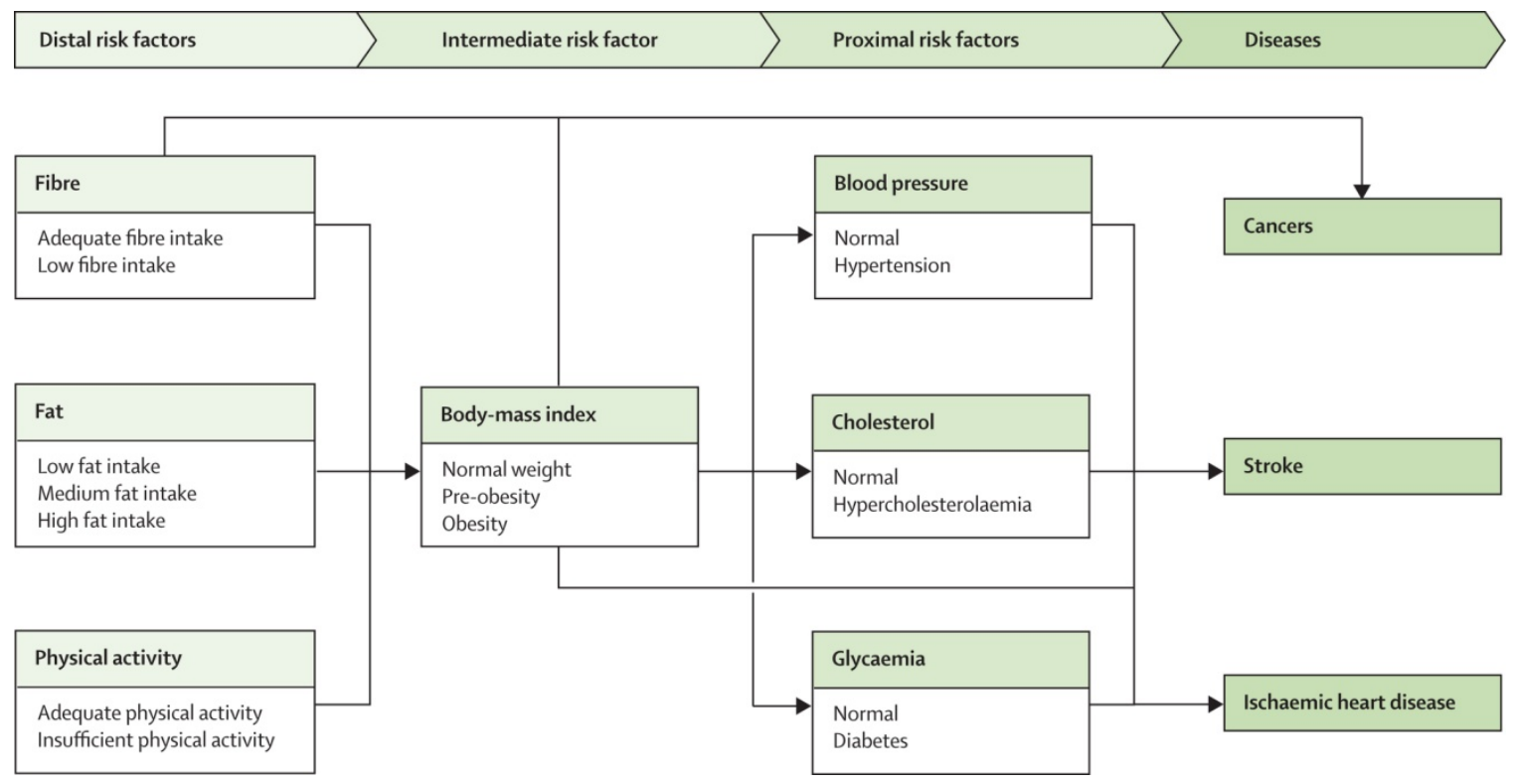

Figure 2-2. Causal web for risk factors and diseases events implemented in the chronic disease prevention model (Cecchini et al., 2010) 
micronutrients associated with hypertension are low intakes of magnesium, potassium, calcium, vitamin A, iron, folic acid, and high intakes of sodium. Consumption of fruits, vegetables, and low-fat dairy products is encouraged to help reduce hypertension (Gokah and Gumpo, 2010).

It has been suggested that overweight and obesity are now the prominent features of malnutrition in South Africa (Cecchini et al., 2010). Nationally, 26.7\% of black women are overweight and $31.8 \%$ are obese (Puoane et al., 2002). Interventions to improve nutrition and decrease overweight/obesity have met with difficulties, mostly because of lack of nutrition knowledge and positive associations with a larger body size (Mvo et al., 1999). One survey of South African women found that the majority of respondents had a relatively good understanding of the causes of obesity, but knowledge of the nutrient content of different foods and appropriate amounts to consume was lacking. Weight loss and thinness are frequently associated with HIV/AIDS, therefore obesity is often seen as a sign of good health (Charlton et al., 2004). Economic factors are also a barrier to good health. The globalization of food markets has introduced large quantities of low-cost, high-calorie foods that are implicated in chronic disease development. In a society where poverty is widespread and chronic hunger continues to be a problem, people eat to survive, not to be healthy (Gokah and Gumpo, 2010).

\subsection{Intervention Programs}

Nutrition programs in South Africa have been in place since the 1960's (Saitowitz and Hendricks, 2010). These programs focused mainly on providing food to the needy and were not highly successful because they did not address underlying causes of 
undernutrition. The new South African democratic government, elected in 1994, took on malnutrition as one of its key priority issues. Subsequently, the Integrated Nutrition Program (INP) was created. This program emphasizes the need to address all causes of malnutrition (Saitowitz and Hendricks, 2010). The eight key focus areas include improving household food security, disease-specific nutritional support, growth monitoring and promotion, nutritional education, support of breast-feeding, control of micronutrient malnutrition, food service management, and a nutrition intervention program for HIV, AIDS, and tuberculosis (Labadarios et al., 2005). Strategies to address micronutrient malnutrition include supplementation, fortification, food aid, promotion of home and community gardens, and encouragement to consume greater quantities of wild vegetables. These interventions will be briefly described, with a separate and more detailed description of wild plant consumption.

\subsubsection{Supplementation}

Supplementation is considered a short term strategy to combat micronutrient deficiencies. A high-dose vitamin A supplement program, intended to be administered twice a year, was introduced in 2002 targeting all children 6 months to 5 years old and postpartum women 6 to 8 weeks after delivery. Vitamin A supplementation is also provided to children with severe undernutrition, xeropthalmia, persistent diarrhea, and measles (Labadarios et al., 2005). As of 2007, 96.4\% of children, 53.7\% of post partum women, and $24.3 \%$ of infants seen at health facilities received these supplements (Mseleku, 2007). Micronutrient supplements in pill or syrup form have also been proposed as part of a nutrition intervention program targeting individuals with HIV, AIDS, and tuberculosis (Labadarios et al., 2005). 
South Africa's Department of Health has made provisions for all pregnant women attending antenatal clinics to routinely receive iron $(175 \mathrm{mg} /$ day ferrous sulphate) and folate (5mg/day) supplements (Mamabolo et al., 2004). Folate supplementation appears to be effective in reducing deficiencies, especially in those who attend clinics early in pregnancy, but results are not as positive for iron status. It is suspected that many women do not take the iron supplement because it causes nausea (Mamabolo et al., 2004).

\subsubsection{Fortification}

Food fortification is considered a relatively inexpensive and sustainable way to eradicate micronutrient deficiencies without changing traditional food intake patterns (Steyn et al., 2007). Mandatory food fortification programs in South Africa began with the iodization of salt intended for human consumption in 1995. It some areas, iodization of salt eliminated iodine deficiency within a year (Schonfeldt and Gibson, 2009). Noniodized agricultural salt, however, continues to be used in 6.5\% of households (Steyn et al., 2007) and 38\% of households use inadequately iodized salt (Labadarios et al., 2005).

In 2003 it became compulsory to fortify maize meal and wheat flour with vitamin A, iron, zinc, folic acid, thiamin, riboflavin, niacin, and vitamin $\mathrm{B}_{6}$ (Steyn et al., 2007). It has been suggested from previous fortification studies that, over approximately five years, one out of four child deaths could be prevented, maternal deaths could decrease by one third, work capacity of the labor force could increase up to $40 \%$, the population intelligence quotient (IQ) could be raised by 10 to 15 points, and the gross domestic product (GDP) could be increased by $5 \%$ at a cost equivalent to only $0.3 \%$ of the GDP (Schonfeldt and Gibson, 2009). A secondary analysis of adult nutrient intake in South Africa indicated that fortification has been relatively successful (Steyn et al., 2007). 
Nutrient levels in men in urban areas have increased to, or above, the recommended nutrient intakes (RNI) for all nutrients except folate. Among urban women, thiamin, folate, and iron intakes remained below the RNI, while only iron remained low among rural women. Despite these improvements, it is acknowledged that fortification cannot solve all micronutrient deficiencies in South Africa. Some nutrients, such as iron, may not be provided in high enough amounts or in highly bioavailabile forms to meet the needs of women of childbearing age. Other nutrients, like calcium, are not included in the fortification mix. It is therefore desirable to pursue other options to improve micronutrient consumption in addition to fortification (Steyn et al., 2007).

\subsubsection{Food aid}

The Protein Energy Malnutrition (PEM) Scheme was initiated in South Africa in the 1960's, targeting children between 6 months and 6 years old who visited local authority clinics and who suffered from or were at risk of undernutrition (Hendricks et al., 2003). In 1991 the PEM Scheme was extended to other vulnerable groups, including pregnant and lactating women, the elderly, and chronically ill. Qualifying individuals receive aid in the form of full-cream milk powder and a protein, vitamin, and mineral mixture, made from fortified maize and milk. It is feared, however, that food supplementation to high risk groups, as is done in the PEM Scheme, is not likely to have maximum benefit if not integrated into a broader package of nutrition interventions (Hendricks et al., 2003). Needy families may also receive food aid through the National Nutrition and Social Development Programme (NNSDP). Food parcels include staples such as maize meal, oil, legumes, and milk powder. This aid was found to decrease rates of underweight, but benefit was only significant in groups that also took part in a 
nutrition education program (Walsh et al., 2002), which supports the theory that food aid needs to be incorporated into other nutrition interventions to be of greatest benefit.

A school feeding program, one of the four focus areas of the Primary School Nutrition Program (PSNP), was implemented in 1994 (DOH, 1993). As of 2005, approximately 15,000 schools were participating (Labadarios et al., 2005). The meals served are intended to provide $25 \%$ of the recommended dietary allowances (RDA) for 7 10 year olds, and should consist of low cost, readily available foods that reflect sound nutrition messages and fit in with local eating habits. The South African Department of Health has claimed that, from the beginning, delivery of poor quality foods has been a problem in the school feeding program (CHU, 1997). Frequent allegations of fraud and corruption at certain schools have also been made. In spite of this, school meals are well received and are believed to help children be more alert in school (Labadarios et al., 2005).

\subsubsection{Home and community gardens}

Food gardens at health facilities, schools, and in the community have been established to help support other nutrition services (Mseleku, 2007). Garden projects are generally implemented to increase household production of fruits and vegetables to supplement a cereal based diet (Faber and Wenhold, 2007). Land in rural and urban areas is limited, but sufficient to grow produce for personal use, and possibly a little extra that can be sold to enable the purchase of animal protein and dairy products (Theron et al., 2007). One successful home-based food production program targeting $\beta$-carotenerich fruits and vegetables was tested in KwaZulu-Natal (Faber et al., 2002a). This program was integrated with a community-based growth monitoring system. Growth 
monitoring sessions were held monthly in various homes, at which demonstration gardens were developed. Mothers attending growth monitoring sessions received guidance on how to develop their own gardens and education on the nutritional benefits of eating their garden produce. Cyclic production and crop rotation were promoted to help meet nutrient needs throughout the year. Dietary data was collected from one hundred mothers attending the sessions one year after the garden program was implemented. Participants were found to have significantly higher intakes of vitamin A, riboflavin, vitamin $\mathrm{B}_{6}$, and ascorbic acid, with no major impact on macronutrient intake (Faber et al., 2002a). A similar intervention was tested in the Eastern Cape province with similar results (Laurie and Faber, 2008).

Community gardens in low-income countries face significant challenges from limited access to land with secure tenure and access to a water supply with uncertain financial benefit (Wills et al., 2009). Community gardens in South Africa receive less support than other programs, most likely due to weak evidence of their impact on nutrition. These gardens also tend to be plagued with problems of theft. Benefits of community gardens, however, go beyond any impact they may have on food security or nutrition. They offer a place where community members can gather and form healthful connections. These benefits have been found regardless of intended purposes of the garden (Wills et al., 2009).

\subsection{Consumption of Wild Edible Plants}

Before the agricultural revolution some 10,000 years ago, hunting and gathering were the only means people had to obtain food. The resulting diet was high in diversity 
and generally supported excellent health (Truswell, 1977). Gathered foods consisted of roots, tubers, stems, rhizomes, leaves, flowers, fruits, nuts, gums, berries, cereals, and legumes from an estimated 7000 different species (Bharucha and Pretty, 2010; Vorster et al., 2007b). Since that time, the world has come to rely on only 12 crops to provide $90 \%$ of caloric intake. Wild plants continue to play an important role in the diets of many populations (Grivetti and Ogle, 2000), but knowledge and use of indigenous plants is declining rapidly. Decreasing use of wild plants has led to less diverse diets and increased nutritional deficiency disorders and disease among many communities (Odhav et al., 2007). Researchers have been suggesting since the 1960's that increased utilization of edible wild plants could provide substantial economic and nutritional benefits (Grivetti and Ogle, 2000) and interest continues to increase (Smith and Eyzaguirre, 2007). These crops have the advantages of higher nutrient values than many cultivated crops (Misra et al., 2008), ease of growth, resistance to pests and diseases, are culturally familiar, and can be easily and inexpensively obtained (Aphane et al., 2002). A brief overview of cultural and nutritional roles of wild edible plants throughout the world will be provided, followed by a more specific review of their position in the KwaZulu-Natal region of South Africa. Reasons for declining consumption of gathered plants were investigated as well as possible means for encouraging increased use.

\subsubsection{General use of wild edible plants}

Culture plays a large part in shaping the use of wild foods in a community, particularly in regards to gender roles and resource management. The duty of collecting wild plants generally falls on the shoulders of women, although in some cultures wild fruits and cereals are considered to be in the male domain (Vorster et al., 2007b). For 
many women, particularly the young, widowed, or elderly who do not have access to farm land, the collection and sale of wild foods is an important source of income (Fleuret, 1979; Misra et al., 2008). Although wild food plants grow without cultivation, many foragers help maintain a healthy supply through activities such as the intentional sowing of some wild seeds, replanting portions of roots, irrigation, and burning to stimulate growth. In Thailand, farmers deliberately propagate a full quarter of the 159 wild food species that they gather (Bharucha and Pretty, 2010). In other communities a more passive approach is taken and wild foods are exclusively gathered in association with other activities, such as grazing cattle, tending farm land, or collecting fuel (Misra et al., 2008). Increasing homogenization of agriculture and non-sustainable use of resources has led to a decline in wild food species in many areas (Bharucha and Pretty, 2010), suggesting a need for more proactive management.

Despite an estimated one billion people consuming wild foods, routine underestimation of their importance and lack of information on nutritional content has led to a sketchy understanding of the role wild edible plants play in people's diets (Bharucha and Pretty, 2010). The little research that has been done suggests that wild plants provide important nutrients to infants and children, pregnant and lactating women, and the elderly (Grivetti and Ogle, 2000). Hunter gatherers, who represent one extreme in wild food consumption, provided approximately $65 \%$ of their daily calories from gathered plants (Truswell, 1977). The !Kung Bushmen of Botswana, who lived as hunter gatherers until the 1980's, experienced frequent mild malnutrition associated with low calorie consumption, but very little micronutrient malnutrition. No obesity, hypertension, or coronary heart disease was present, serum cholesterol concentrations were low, teeth 
were healthy, and people enjoyed long lives (Truswell, 1977). The Otomí Native Americans living north of Mexico City are another example of a community that relied heavily on gathered foods. Despite extreme poverty and unsanitary conditions, a diet rich in wild edible plants allowed the Otomí to be well nourished (Grivetti and Ogle, 2000).

At the other end of the spectrum, many communities use indigenous food plants to supplement diets based on more conventional staple crops or as a safety net during times of famine. In much of Africa a relish is made from wild leafy greens, rich in calcium, phosphorus, iron, vitamin A, and niacin, as well as a being a significant source of protein, to accompany their predominantly maize based diet (Fleuret, 1979). Wild fruits snacked on throughout the day by school children in Kenya provide another valuable source of vitamins and minerals, particularly carotenoids and vitamin $\mathrm{C}$ (Grivetti and Ogle, 2000). In addition to these nutrients, wild plants have also been noted to be important sources of essential fatty acids, zinc, and riboflavin (Bharucha and Pretty, 2010).

\subsubsection{Wild edible plants in KwaZulu-Natal, South Africa}

Persistent malnutrition, growing rates of diet-related chronic disease, and the increasing burden of HIV/AIDS has drawn researchers' and policy makers' attention to the use of wild edible plants in South Africa to improve the typical nutrient poor cereal based diet (Aphane et al., 2002). Wild foods are rich sources of the minerals and antioxidant nutrients needed for a healthy immune system. Because indigenous plants are adapted to local conditions and will grow with no outside input, they are also an affordable and practical means of improving nutrition. They can provide resource-poor people with a more diverse, nutrient-dense diet than can be affordably purchased (van der 
Walt et al., 2009a). It is believed that rural Africans still possess knowledge of wild foods (Modi et al., 2006), but most now consider them weeds and do not eat them (Afolayan and Jimoh, 2009). KwaZulu-Natal province is one of the areas of South Africa with the highest rates of malnutrition, food insecurity, and disease burden and has recently been the center of focus for research on wild vegetables (Aphane et al., 2002). Areas of specific importance are knowledge and use of indigenous plants, availability, and nutrient composition.

Knowledge. Various studies and focus group discussions have been held to identify local knowledge of wild edible plants (Faber et al., 2010; Modi et al., 2006). These studies have revealed that, while the majority of respondents recognized the nutritional and economic benefits of gathered foods (Faber et al., 2010), extent of knowledge is diminishing. There are an estimated 1,400 edible plant species in southern Africa, many of which can be found in KwaZulu-Natal (Wehmeyer, 1986), yet a focus group discussion held among subsistence farmers in one rural village revealed participants were familiar with an average of only five to nine edible plants, with people over the age of 70 recalling most and poorly educated individuals and those 54 years old and younger recalling the least number of edible plants (Modi et al., 2006). Another study was able to identify 20 different leafy vegetables during a field walk using highly knowledgeable key informants, but subsequent focus groups narrowed this list down to only six plants that were widely known. Amaranth (Amaranthus spp) is the most commonly consumed wild plant, followed by blackjack (Bidens spinosa), although a blend of wild leaves, called imifino, is also common (Faber et al., 2010). Older women in the community tended to be the most knowledgeable, with younger girls being only 
familiar with the most common and abundant wild vegetables (Vorster et al., 2007b). Traditionally, mothers and grandmothers are the main source of information on indigenous plants, but the radio and clinic staff were also reported to be important sources of information in KwaZulu-Natal (Faber et al., 2010).

Availability. Intensive cultivation of field crops has led to a drastic decline in the availability of indigenous vegetables (Odhav et al., 2007). Crop diversity had formerly been preserved to some degree through the appointment of an older woman of high status as seed custodian for the community, but this position has been lost due to various social and economic pressures (Vorster et al., 2007a). Despite these draw backs, wild vegetables still grow in abundance around rural homesteads in South Africa and are typically available from May through September (Modi et al., 2006). In some regions of South Africa greens are dried and stored for use in the off season, but this is not done in KwaZulu-Natal (Faber et al., 2010). Wild vegetables have been found to be available in greater quantity and variety in cultivated fields than in the veld, or wild lands. It is estimated that, during the peak of the growing season, the wild vegetables growing on only one square meter of cultivated ground could meet the nutrient needs of a family of six for a week (Modi et al., 2006). Wild fruits are abundant in KwaZulu-Natal and can be harvested year-round, although availability is highest from January to September (Fentahun and Hager, 2009).

Nutrient composition. Researchers have begun compiling data on the nutrient composition of wild edible plants in South Africa, but many gaps remain. In general, wild leafy greens can significantly contribute towards dietary requirements for calcium, magnesium, iron, potassium, zinc, vitamins $\mathrm{C}$ and $\mathrm{A}$, folate, and essential fatty acids 
(Faber et al., 2010; van der Walt et al., 2009b). Nutrient content is generally comparable or superior to that of more conventional vegetables, as can be seen in the comparison of the wild vegetables amaranth and imifino with the more commonly consumed cabbage and spinach (Table 2-2) (Maunder and Meaker, 2007; van der Walt et al., 2009a).

Table 2-2. Comparison of nutrient composition per 100g of cooked wild and conventional green leafy vegetables (Maunder and Meaker, 2007)

\begin{tabular}{|c|c|c|c|c|c|c|c|c|c|c|c|c|c|c|}
\hline Food & 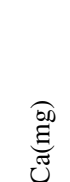 & 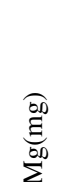 & 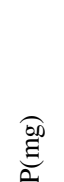 & 兽 & 命 & हू & 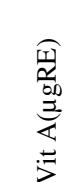 & 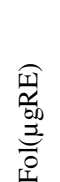 & 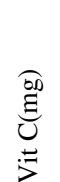 & 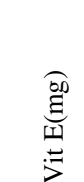 & 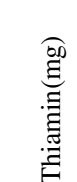 & 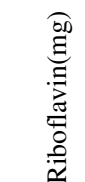 & 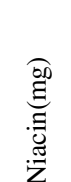 & 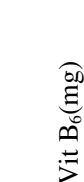 \\
\hline Amaranth & 187 & 37 & 38 & 4.6 & 0.81 & 0.3 & 399 & 5 & 1 & 0.26 & $\operatorname{tr}^{5}$ & 0.04 & 0.3 & 0.05 \\
\hline Imifino $^{\dagger}$ & 106 & 43 & 55 & 2.5 & 0.38 & 0.9 & 253 & 69 & 18 & 1.13 & 0.21 & 0.21 & 1 & 0.145 \\
\hline Spinach & 136 & 59 & 27 & 1.3 & 0.56 & 1 & 168 & 23 & 2 & 0.23 & 0.08 & 0.1 & 0.4 & 0.162 \\
\hline Cabbage & 29 & 9 & 24 & 0.4 & 0.17 & 0.6 & 2 & 11 & 20 & 0.2 & 0.02 & 0.01 & 0.2 & 0.05 \\
\hline
\end{tabular}

\subsubsection{Reasons for declining consumption}

The overwhelming reason given for not consuming wild plants in KwaZulu-Natal is their association with poverty and 'backward knowledge' (Vorster et al., 2007b). Consumption, however, is decreasing throughout the world even in places where it has no negative connotations (Misra et al., 2008). Many reasons have been noted for this. As was previously mentioned, availability of wild crops has declined with intensification and expansion of agriculture (Bharucha and Pretty, 2010). Years of criticism from researchers and extension personnel directed at farmers for not keeping weeds under control has also degraded opinions of these plants. Knowledge is not being passed to younger generations due to time devoted to school (Vorster et al., 2007b) and decreased value placed on wild food sources as store-bought foods become more available (Bharucha and Pretty, 2010). Traditional preparation of gathered plants tends to be very 
monotonous (Vorster et al., 2007a). Local knowledge is also lost when populations are removed from familiar resources, as frequently happened during apartheid in South Africa (Haag and Hajdu, 2005). In most areas of the world, reasons for not consuming wild plants seem to be a combination of many of these factors.

\subsubsection{Suggestions for encouraging use}

A list of ideas on how to increase wild edible plant consumption has been generated by representatives of several indigenous groups, a portion of which is represented in Table 2-3. In creating this list it was recognized that the best approach to increase indigenous plant consumption would require collaboration with community leaders, women, and academic partners and would depend upon community support and a sense of dignity in local ways (Kuhnlein et al., 2006). Because of associations with poverty, promotion of wild edible plants should focus on the potential nutritional and health benefits of consumption rather than affordability (Faber et al., 2010). An intervention tested in several rural areas of South Africa between January, 2000 and April, 2003 involved recipe and cooking competitions, cultivation of traditional leafy

Table 2-3. Ideas for supporting indigenous food systems (Kuhnlein et al., 2006)

- Gain more access to land/water needed to improve harvests

- Teach food harvesting and preparation to youth

- Stimulate home or community gardens and local food production

- Distribute traditional plantings: trees, shrubs, seedlings, seeds

- Work with local extension agents for better harvests, emphasizing nutrient rich local food varieties

- Target curriculum and learning in schools around local food and nutrition

- Involve the children to take messages home

- Hold local food preparation classes

- Involve elders and work with culture committees

- $\quad$ Train all community health workers about traditional food resources

- Work with the mass media-radio, television, newspapers-to promote local indigenous foods to raise status of local food and acknowledge those involved 
vegetables, production training, and awareness activities. Excitement and confidence in traditional crops grew among community members as the sincerity of researchers became apparent. Children also showed enthusiasm during at-school trainings and many took the knowledge they gained home to share with their parents. The success of this intervention has shown that increasing long-term awareness and consumption of wild edible plants is likely to be a time consuming and expensive process, but it can be done (Vorster et al., 2007a). A second intervention, titled "African Roots," promoted food gardens and the use of traditional crops in association with organic farming techniques. Attempts were made to decrease the stigma attached to wild plants through posters and advertisements. Many participants, however, did not see the benefit of more obscure traditional plants and the stigma attached to them persisted. Despite these problems, many people did become enthusiastic about the idea of looking to their past to confront some of today's problems (Kaschula and Arbuckle, 2007).

\subsection{Modeling Methods}

The process of identifying the optimal blend of foods needed to meet nutrient requirements of a population begins with collecting baseline data on current intakes of that population. There are several methods to do this, including 24-hour recall, food frequency questionnaires, and food records. Seasonal differences in food availability and intake are common in many communities, and so these differences also need to be measured to determine if potential interventions need to differ by season. To maintain maximum flexibility in food choice, it is desirable to aggregate foods with common nutrient profiles into composite food groups to be used as the basis for recommendations. 
This information can then be used to create a model predicting the optimal blend of foods to meet nutrient needs using linear programming.

\subsubsection{Dietary Assessment}

24-hour recall. The 24-hour recall method tends to be the primary instrument used to monitor diet. This method provides rich detail on the types and amounts of foods eaten by an individual (Dodd et al., 2006). In essence, a 24-hour recall involves obtaining a record of all foods and beverages consumed in the previous 24 hours by an individual. This is often facilitated by a clinician or other trained interviewer who guides the subject through the previous day's intake (Nelms et al., 2007). The 24-hour recall records can also be completed by an individual independently. Photographs and food models may be used to help determine portion sizes (Bingham et al., 1994). Advantages of this method include low respondent burden, short administration time, and low cost. Disadvantages include dependence on memory, respondents may alter responses to meet interviewer expectations, and results may not reflect typical eating patterns (Nelms et al., 2007).

Food frequency questionnaire. Food frequency questionnaires are the primary tool for diet assessment used in epidemiology (Dodd et al., 2006). This method allows individuals to identify how often and in what approximate quantity a specific food or food group is consumed over a long-term period, such as a year or several months. These questionnaires may be self-administered and can be tailored to reflect typical diets of different populations, or be specialized to identify intakes associated with certain conditions. They are quick, easy, and affordable, but do not provide valid estimates of actual nutrient intakes, cannot assess meal patterning, and foods on the pre-prepared list 
may not be appropriate for all individuals. Because of this, food frequency

questionnaires need to be validated before use with any new population to ensure that the food list used is reflective of local diet patterns (Nelms et al., 2007).

Food records. Food records, or food diaries, are similar to 24-hour recall measures, but intake is measured and recorded at the time of consumption by the individual. Time periods typically span 3 or 5 days, which should represent both weekend and weekday consumption. Advantages of this method include no reliance on memory and better representation of actual intake. Disadvantages include a high respondent burden, the need for literacy, underreporting, and a tendency to alter food habits for the recording period (Nelms et al., 2007).

\subsubsection{Seasonality}

Seasonal variations in climate and crop patterns are common in most communities. These seasonal differences can lead to significant differences in nutrient intake throughout the year, especially in communities with a distinct wet and dry season and when the population is mainly dependent on locally grown crops (Bates et al., 1994). These seasonal differences have varying impacts. For example, a study of school-aged children in Benin revealed seasonal differences in types of foods eaten, but little variation in nutrient intake throughout the year (Mitchikpe et al., 2008). Seasonal weight loss and differences in macronutrient proportions contributing to energy intake were found among women of the Democratic Republic of Congo (Bentley et al., 1998). Pregnant and lactating women in rural Gambia were found to have significant seasonal variations in vitamin A and vitamin C intake (Bates et al., 1994). These seasonal variations are generally measured by collecting dietary intake data in the dry (post-harvest) season 
when food tends to be most plentiful, and the wet (pre-harvest) season, which is often labeled the hunger season. Nutrient intakes in each season can be compared using paired or unpaired t-tests (Bates et al., 1994; Bentley et al., 1998; Mitchikpe et al., 2008;

Nordeide et al., 1996).

\subsubsection{Food group composites}

Studies have found that a count of the number of food groups eaten is an adequate proxy indicator of micronutrient intake (Kennedy et al., 2010). Major food groups can be divided into subgroups to highlight nutrients of particular concern. In developing the United States Department of Agriculture's Food Guide, all fruits were aggregated into one group while vegetables were divided into five subgroups: dark-green, deep-yellow, dry beans and peas, other starchy, and other. Composite nutrient profiles for these groups were then created to reflect typical consumption of foods from within that group based on national dietary surveys (Welsh et al., 1993), as described by the following equation:

$$
\sum\left[\left(\begin{array}{c}
\text { Nutrient contribution } \\
\text { of each food }
\end{array}\right) \times\left(\begin{array}{c}
\text { Likelihood of each } \\
\text { food being eaten }
\end{array}\right)\right]=\text { Nutrient profile of food group }
$$

For example,

$$
\sum[(943 \times .15)+(153 \times .36)+\cdots+\cdots \text { etc }]=334 \mu \mathrm{g} \text { RAE vitamin A/cup }
$$

where one cup of cooked spinach contains $943 \mu \mathrm{g}$ RAE vitamin A and accounts for $15 \%$ of dark green vegetable consumption as reported in NHANES 99-00, one cup cooked 
broccoli contains $153 \mu \mathrm{g}$ RAE vitamin A and accounts for $36 \%$ of dark green vegetables, and so forth, to create a composite value of $334 \mu \mathrm{g}$ RAE vitamin A per cup of dark green vegetables (Marcoe et al., 2006).

\subsubsection{Linear programming}

Approaches for designing population specific recommendations based on locally available foods typically involve expert consultation, taking into account multiple factors such as most common nutritional problems, cultural food consumption patterns, availability and affordability of foods, realistic portion sizes, and the impact of recommendations on other nutrients and the environment. Linear programming is a type of analysis that can simplify this process by simultaneously taking into account multiple factors to determine the optimal combinations of foods that will meet all requirements (Ferguson et al., 2006). Linear programming is a type of optimization problem, the goal of which is to select values that optimize a given objective function, or linear expression, subject to certain constraints (Ferris et al., 2007). For example, the objective function may ensure that an optimal food plan departs as little as possible from normal consumption while meeting nutrient requirements at the lowest price, with restrictions placed on energy density and how much food can come from each food group. The general structure of the model is as follows (Masset et al., 2009):

$$
\begin{array}{r}
\text { Minimize/maximize: } \mathrm{Y}\left(\mathrm{x}_{1}, \mathrm{x}_{2}, \mathrm{x}_{\mathrm{n}}\right)=\mathrm{a}_{1} \mathrm{x}_{1}+\mathrm{a}_{2} \mathrm{x}_{2}+\cdots+\mathrm{a}_{\mathrm{n}} \mathrm{x}_{\mathrm{n}}+\mathrm{b} \\
\text { Subject to }\left\{\begin{array}{c}
\mathrm{x}_{1}<A \\
\mathrm{x}_{2}>B \\
\cdots \\
\mathrm{x}_{\mathrm{n}}=\mathrm{N}
\end{array}\right.
\end{array}
$$


Linear programming has widespread applications. In the realm of nutrition, linear programming can be used to create population guidelines, such as the USDA's thrifty food plans (Carlson et al., 2006), food based dietary guidelines (Ferguson et al., 2004), identify problem nutrients (Ferguson et al., 2006), or it can be used to develop individual diet plans based on personal nutrient needs and food preferences (Soden and Fletcher, 1992). Major limitations to using this approach to optimize diets include the time required to set up the models, sensitivity of results to data accuracy, and the need for a competent analyst. It is hoped that in the future a more user-friendly interface will be developed to make linear programming a method that can be used in various settings with limited understanding of the underlying process (Ferguson et al., 2006).

\subsection{Conclusion}

South African dietary guidelines recommend the consumption of a variety of foods, including plenty of fruits and vegetables, each day to help improve health and well being (Maunder and Meaker, 2007), yet many individuals lack the necessary resources to follow these recommendations. Increasing consumption of wild edible plants has been proposed as the most efficient approach to solve this problem. Populations who rely heavily on gathered foods generally enjoy excellent health, but significant benefit can also be obtained by using wild foods to supplement more conventional staples. Unfortunately, both awareness and use of wild edible plants is decreasing due to negative associations, decreased availability, and knowledge not being passed from older to younger generations. It is possible to reverse these trends, but it will not be an easy or fast process. A successful intervention program will require an understanding of and 
manipulation of the forces that have brought about current dietary trends, acknowledgement of additional needs and challenges presented by high rates of disease, cooperation with other intervention programs already in place, and specific, measurable recommendations on quantity and varieties of wild foods to promote. 


\section{CHAPTER 3}

\section{MATERIALS AND METHODS}

\subsection{Objective}

To determine the optimal blend of South African wild edible plants needed to fill gaps between typical micronutrient consumption and requirements for lactating women in KwaZulu-Natal, South Africa.

\subsection{Subjects}

The Maternal Nutrition (MN) study was conducted between May 2002 and August 2004 in rural northern KwaZulu-Natal, South Africa, to investigate the nutritional status of HIV-infected and HIV-uninfected breastfeeding mothers (Papathakis et al., 2007). The population in this area is predominantly of Zulu ethnic origin and is characterized by high rates of HIV infection, unemployment, poor access to clean water, and a high infant mortality rate (Hosegood, 2001). Most of the observed mothers were simultaneously participating in the Africa Centre Vertical Transmission (VT) study, investigating the relationship between exclusive breastfeeding and transmission of HIV from mother to child (Bland et al., 2010). Additional HIV-negative mothers were recruited outside of the VT study to participate in the MN study. All HIV-positive pregnant women attending antenatal clinics in the region were invited to participate. HIV-negative pregnant women were recruited through a time-related random sample of women attending the same clinics. Women who intended to return to school or work within 2 months following delivery or leave the area within 3 months were excluded. Enrollment in the MN study began at approximately 6 weeks post partum and follow-up 
visits took place at 14, 24, 36, and 48 weeks post partum. The 24-hour recall records were collected at each study visit and are available for 142 women. Records were obtained in participants homes by trained Zulu speaking staff members so that usual portions and products consumed could be more accurately determined (Papathakis et al., 2007).

Demographic characteristics of 116 of the women participating in both the VT and MN studies are presented in Table 3-1. Ages ranged from 14 to 50 years. Thirty five percent of the women had recently given birth to their first child. Although HIV-positive individuals $(\mathrm{n}=78)$ are represented in a higher proportion than is found in the population, demographic characteristics did not differ significantly between HIV-positive and negative groups (Papathakis et al., 2007). Average BMIs at 24-weeks postpartum were $24.1 \mathrm{~kg} / \mathrm{m}^{2}$ for HIV+ women and $25.7 \mathrm{~kg} / \mathrm{m}^{2}$ for HIV- women. Thirty eight percent of HIV- and $23 \%$ of HIV+ mothers were overweight. Differences in average BMI and overweight prevalence between HIV+ and HIV- mothers were not statistically significant (Papathakis et al., 2006).

Table 3-1. Baseline characteristics of breastfeeding mothers. $\mathrm{n}=116$ (Adapted from Papathakis et al., 2007)

\begin{tabular}{lc}
\hline Age (y) & $26 \pm 7.3^{\dagger}$ \\
Previous pregnancies & $1.5(0-7)^{\ddagger}$ \\
HIV+ $(\%)$ & 67.2 \\
Paid employment (\%) & 8.6 \\
Cement household structure (\%) & 52.6 \\
Water source (\%) & \\
$\quad$ Pond or dam & 24.1 \\
$\quad$ Public tap & 29.3 \\
Toilet (\%) & \\
$\quad$ None & 41.4 \\
Open pit latrine & 50.9 \\
Cooking fuel (\%) & \\
$\quad$ Pood & 61.2 \\
Refrigerator use $(\%)$ & 12.9 \\
\hline${ }^{\dagger}$ Mean \pm standard deviation $\quad{ }^{*}$ Mean and range & 29.3 \\
\hline
\end{tabular}




\subsection{Diet}

Data from the 24-hour recalls collected at each study visit were entered into FoodFinder®, a diet analysis program developed for use in South Africa, to determine nutrient intake. A total of 504 records were collected from 142 women, with each woman having an average of 3.5 records (24\% had two or less, $43 \%$ had three or four, and $33 \%$ had five or more). Each woman's average intake was determined and used to find the mean intake for the group.

A mandatory food fortification program was initiated in South Africa in October of 2003, requiring that maize meal and wheat flour be fortified with iron, zinc, vitamin A, thiamine, riboflavin, niacin, vitamin $\mathrm{B}_{6}$, and folic acid (Steyn et al., 2007) that had to be taken into consideration when determining the baseline diet of these women. Based on surveys of local stores and bakeries, it is estimated that the women in this area of South Africa began consuming the fortified products by January 14, 2004. All foods entered into FoodFinder® after that date used updated nutrient content of fortified foods (Papathakis, 2011). Thirty four individuals had diet records from both before and after January $14^{\text {th }}$, with each woman having an average of 3.0 records before fortification and 1.5 after. Average nutrient intake pre-fortification of these 34 individuals did not significantly differ from the average intake of all women before fortification (Table 3-2). In the subsample of 34, after determining each woman's average intake before and after fortification, average intakes from each period were compared using paired t-tests to determine the difference in nutrient consumption (Table 3-3). Logarithmic transformations for riboflavin and vitamin $\mathrm{B}_{6}$ and a square root transformation for folate were used to satisfy assumptions of normality. The average increases in nutrient intake 
post-fortification were then added to all food records of the 142 women from before January $14^{\text {th }}$, and then each woman's food records were averaged so that micronutrient intake would reflect probable modern levels. Two-sample t-tests using a significance level of $\alpha=0.05$ were performed to determine if HIV status or season impacted nutrient intake, but no significant differences were found (data not shown).

Table 3-2. Average pre-fortification intakes of fortified nutrients for all women $(n=142)$ compared to intakes of the sub-sample with records both before and after fortification $(n=34)$

\begin{tabular}{lccc}
\hline & All $(\mathrm{n}=142)$ & Sub-sample $(\mathrm{n}=34)$ & P-value \\
\hline Iron $(\mathrm{mg})$ & 7.2 & 6.7 & 0.200 \\
Zinc $(\mathrm{mg})$ & 5.7 & 5.4 & 0.247 \\
Vitamin A $(\mu \mathrm{g} \mathrm{RE})$ & 114 & 86 & 0.280 \\
Thiamin $(\mathrm{mg})$ & 0.87 & 0.86 & 0.888 \\
Riboflavin $(\mathrm{mg})$ & 0.40 & 0.35 & 0.125 \\
Niacin $(\mathrm{mg})$ & 8.90 & 7.99 & 0.185 \\
Vitamin $\mathrm{B}_{6}(\mathrm{mg})$ & 0.67 & 0.60 & 0.209 \\
Folate $(\mu \mathrm{g})$ & 200 & 183 & 0.227 \\
\hline
\end{tabular}

Table 3-3. Average difference in fortified nutrient intake following fortification of maize and wheat products

\begin{tabular}{lcccc}
\hline & $\begin{array}{c}\text { Pre-fortification } \\
\mathrm{n}=34\end{array}$ & $\begin{array}{c}\text { Post-fortification } \\
\mathrm{n}=34\end{array}$ & Difference & $\mathrm{P}$ \\
\hline Iron $(\mathrm{mg})$ & 6.7 & 13.9 & 7.2 & $<0.001$ \\
Zinc $(\mathrm{mg})$ & 5.37 & 7.68 & 2.31 & $<0.001$ \\
Vitamin A $(\mathrm{RE})$ & 86 & 442 & 356 & 0.001 \\
Thiamin $(\mathrm{mg})$ & 0.86 & 1.15 & 0.29 & $<0.001$ \\
Riboflavin $(\mathrm{mg})$ & 0.35 & 0.70 & 0.35 & $<0.001$ \\
Niacin $(\mathrm{mg})$ & 7.99 & 13.66 & 5.66 & $<0.001$ \\
Vitamin $\mathrm{B}_{6}(\mathrm{mg})$ & 0.60 & 1.31 & 0.70 & $<0.001$ \\
Folate $(\mu \mathrm{g})$ & 182 & 456 & 274 & $<0.001$ \\
\hline
\end{tabular}

When evaluating the nutrient intake of a population, it is desirable for the population average to equal the Estimated Average Requirement (EAR), which describes the level of nutrient needed to meet the needs of $50 \%$ of individuals. When making individual recommendations for nutrient consumption, higher values are suggested (Medicine, 2000). For the present study, two different values were considered in 
determining the amount of each nutrient required to optimize the dietary intakes of these lactating women. The first value identified the amount of nutrient intake needed to meet the needs of $50 \%$ of women, while the second amount met the needs of $75 \%$ of women. These levels were determined by ranking nutrient intake by quartile and then subtracting the median $(50 \%)$ and first quartile (75\%) values respectively from the EAR. The percentage of women consuming less than the EAR was also identified. Nutrients for which more than half of the women were consuming less than the EAR were targeted for optimization.

\subsection{Nutrient profiles of wild edible plants}

A list of wild edible plants available in KwaZulu-Natal and their nutrient profiles were collected from previously published sources (Odhav et al., 2007; USDA, 2005; Wehmeyer, 1986). Plants used exclusively for oil, gum, alcoholic beverages, and for medicinal purposes were excluded. Items with improbable energy content for the specified food type were also excluded. The wild edible plants were then organized into food groups: leafy green vegetables $(n=32)$, fruit $(n=47)$, roots and tubers $(n=9)$, and seeds, nuts, and grains $(n=9)$. Nutrient concentrations of boiled leafy greens were used when possible, but these were available for only three of the leafy vegetables (Amaranthus sp., P. oleracea, and U. urens). All other values are for raw foods. Composite nutrient profiles for the food groups were then created for use in modeling. An attempt was made to weight nutrient profiles so that commonly consumed items, as determined by food records of the 142 women and published literature, would account for a greater proportion of nutrients. Leafy greens were the only wild foods eaten by this sample and were also the only type of wild edible plants for which information could be 
found indicating regular rates of consumption in the region. Amaranth was the only wild leafy green consumed by the sample, and so was assigned $20 \%$ weight. Odhav et al. (2007) identified 8 other leafy vegetables as being regularly consumed in this area $(B$. pilosa, C. triloba, C. album, C. monophylla, G. parviflora, M. balsamina, P. oleracea, and S. nigrum). Each of these eight was assigned 5\% weight, for a group total of $40 \%$. An equally distributed average of the remaining 23 locally available leafy greens accounted for the last $40 \%$. These less common leafy greens were preserved in calculating the composite nutrient profile because it is hoped that their consumption will increase. The equation for determining the weighted leafy green vegetable composite nutrient profile can be summarized as follows:

$$
\sum(\text { Amaranth } \times .2)+(\text { Regularly consumed } \times .4)+(\text { Remainder } \times .4)
$$

In the other three food groups, each item was equally represented in determining the composite nutrient profile. No information was available on the vitamin A content of roots and seeds; folate content of fruit, roots, and seeds; vitamin C content of seeds, and the vitamin $\mathrm{B}_{6}$ content of all groups. Nutrient values from equivalent food groups developed by the United States Department of Agriculture (Marcoe et al., 2006) therefore were used as estimates of these values so that these nutrients could be included in the optimization models. The USDA reports food amounts as servings rather than grams, so the number of calories in each serving was used to determine the amount of nutrient in each 100g serving of wild edible plants. For example, according to the USDA, a $59 \mathrm{kcal}$ 
serving of fruit contains $24 \mu \mathrm{g}$ of folate, so an $80 \mathrm{kcal}$ (equivalent to $100 \mathrm{~g}$ ) serving of wild fruits was assumed to contain $32 \mu \mathrm{g}$.

\subsection{Optimizing intake}

Linear programming, using Lindo software (LINDO Systems, 2002), was used to determine the optimal blend of wild edible plants that would need to be eaten to meet needs of lactating women in KwaZulu-Natal for calcium, zinc, copper, vitamin A, thiamin, riboflavin, folate, and vitamin C. Despite inadequate intakes, vitamins $B_{12}$ and D were excluded from the model because they cannot be provided by wild edible plants. Linear programming analysis simultaneously considered the amount of each nutrient provided by each wild food group to determine the smallest total amount of wild edible plants that could to be consumed to fill nutrient gaps. Two different optimization models were originally created. The first found the amount of wild edible plants required in addition to the current diet to meet the needs for each nutrient for $50 \%$ and $75 \%$ of women. The second was an isocaloric model in which all additional calories from wild edible foods would replace the equivalent number of calories from maize meal, which is the staple food consumed in the greatest amounts in this population. It was discovered, however, that no practical solutions were possible for this model. A third, semiisocaloric model representing the midpoint between these two models, was then developed in which it was assumed that half the additional calories that would be consumed would replace an equivalent amount of calories from maize meal, meaning that for every $100 \mathrm{kcal}$ increase in wild edible plant consumption, maize meal consumption would decrease by $50 \mathrm{kcal}$. 
The first model, which determined the quantity of wild edible plants needed in addition to current diet, was calculated in two ways. The first method minimized the total number of additional grams of food provided while the second minimized the total number of calories provided. As an example, the model minimizing total grams is presented in equation 2 (using 50\% nutrient gap values). As shown in Figure 3-1, letter variables represent grams of each food group composite needed to fill nutrient gaps: leafy vegetables $(\mathrm{L})$, fruits $(\mathrm{F})$, roots and tubers $(\mathrm{R})$, and seeds, nuts, and grains $(\mathrm{S})$. Number values preceding variables represent the amount of the specified nutrient per gram of that food group, as calculated from the food group composite nutrient profiles. Inequalities, or the result of the equation, represent the amount of each nutrient that needed to be supplied. The objective function describes the overall goal, in this case minimizing the total amount of each food group used. The model minimizing total calories was set up in the same way, except variables represented the number of calories of each food group needed to fill gaps and number values represented the amount of each nutrient provided in one calorie of each food group. Table 3-4 shows the amounts of each nutrient per unit of each food group used in all models.

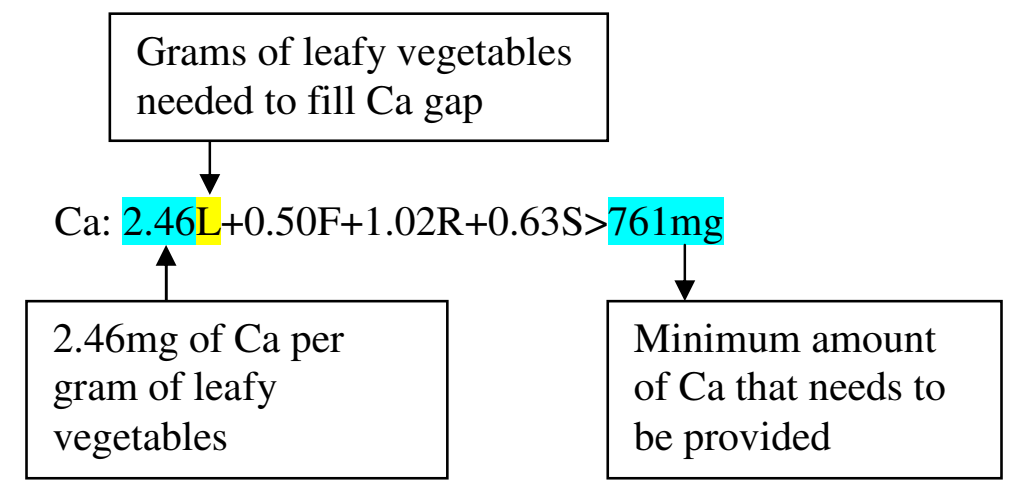

Figure 3-1. Explanation of the components involved in the optimization function 
Objective function: Minimize $\mathrm{L}+\mathrm{F}+\mathrm{R}+\mathrm{S}$

Subject to:

$$
\begin{aligned}
& \text { Ca: } 2.46 \mathrm{~L}+0.50 \mathrm{~F}+1.02 \mathrm{R}+0.63 \mathrm{~S}>761 \mathrm{mg} \\
& \text { Zn: } 0.012 \mathrm{~L}+0.003 \mathrm{~F}+0.006 \mathrm{R}+0.031 \mathrm{~S}>2.41 \mathrm{mg} \\
& \mathrm{Cu}: 0.003 \mathrm{~L}+0.003 \mathrm{~F}+0.002 \mathrm{R}+0.012 \mathrm{~S}>0.09 \mathrm{mg} \\
& \text { Vitamin A: } 5.41 \mathrm{~L}+0.44 \mathrm{~F}+0.071 \mathrm{R}+0.0 \mathrm{~S}>339 \mathrm{RE} \\
& \text { Thiamin: } 0.00056 \mathrm{~L}+0.00072 \mathrm{~F}+0.00046 \mathrm{R}+0.0055 \mathrm{~S}>0.11 \mathrm{mg} \\
& \text { Riboflavin: } 0.0017 \mathrm{~L}+0.0006 \mathrm{~F}+0.0003 \mathrm{R}+0.0016 \mathrm{~S}>0.56 \mathrm{mg} \\
& \text { Vitamin C: } 0.37 \mathrm{~L}+0.30 \mathrm{~F}+0.07 \mathrm{R}+0.0 \mathrm{~S}>40.6 \mathrm{mg} \\
& \text { Vitamin } \mathrm{B}_{6}: 0.0035 \mathrm{~L}+0.0017 \mathrm{~F}+0.0021 \mathrm{R}+0.0021 \mathrm{~S}>0.29 \mathrm{mg}
\end{aligned}
$$

Limits were set on each food group to ensure portion sizes did not exceed amounts estimated to be reasonable. Limits for leafy greens and fruit were set at $250 \mathrm{~g}$, or 105 $\mathrm{kcal}$, and $375 \mathrm{~g}$, or $300 \mathrm{kcal}$, respectively based on weight or calories, which is slightly less than twice the national recommendation for total fruit and vegetable consumption of 400 grams per day (Maunder and Meaker, 2007). Roots and seeds were limited to $150 \mathrm{~g}$ (110 kcal) and $100 \mathrm{~g}(380 \mathrm{kcal})$ so that leafy greens and fruits would be emphasized in the mixtures. 
Table 3-4. Values used in different linear programming models representing the amount of each nutrient provided per unit food (per gram, per calorie, or per calorie minus $1 / 2$ calorie maize meal)

\begin{tabular}{|c|c|c|c|c|c|c|c|c|c|}
\hline & & $\mathrm{Ca}(\mathrm{mg})$ & $\mathrm{Zn}(\mathrm{mg})$ & $\mathrm{Cu}(\mathrm{mg})$ & $\begin{array}{c}\text { Vit A } \\
(\mu \mathrm{g} \mathrm{RE})\end{array}$ & $\begin{array}{l}\text { Thiamin } \\
(\mathrm{mg})\end{array}$ & $\begin{array}{l}\text { Riboflav } \\
(\mathrm{mg})\end{array}$ & $\begin{array}{l}\begin{array}{l}\text { Vit C } \\
(\mathrm{mg})\end{array} \\
\end{array}$ & $\begin{array}{l}\text { Vit } B_{6} \\
(\mathrm{mg})\end{array}$ \\
\hline \multirow{4}{*}{ 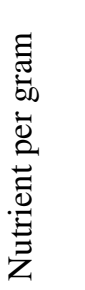 } & $\mathrm{L}$ & 2.460 & 0.012 & 0.003 & 5.41 & 0.0006 & 0.0017 & 0.367 & 0.004 \\
\hline & $\mathrm{F}$ & 0.501 & 0.003 & 0.003 & 0.44 & 0.0007 & 0.0006 & 0.298 & 0.002 \\
\hline & $\mathrm{R}$ & 1.017 & 0.006 & 0.002 & 0.071 & 0.0005 & 0.0003 & 0.068 & 0.002 \\
\hline & $S$ & 0.626 & 0.031 & 0.012 & 0.0 & 0.0055 & 0.0016 & 0.0 & 0.002 \\
\hline \multirow{4}{*}{ 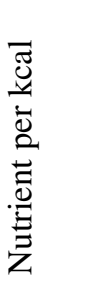 } & $\mathrm{L}$ & 5.872 & 0.027 & 0.008 & 12.91 & 0.001 & 0.004 & 0.876 & 0.008 \\
\hline & $\mathrm{F}$ & 0.629 & 0.004 & 0.004 & 1.24 & 0.001 & 0.001 & 0.375 & 0.002 \\
\hline & $\mathrm{R}$ & 1.376 & 0.009 & 0.003 & 0.15 & 0.001 & 0.0004 & 0.092 & 0.003 \\
\hline & $S$ & 0.166 & 0.008 & 0.003 & 0.0 & 0.001 & 0.0004 & 0.0 & 0.001 \\
\hline \multirow{4}{*}{ 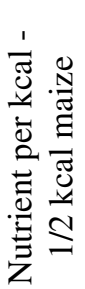 } & $\mathrm{L}$ & 5.866 & 0.025 & 0.008 & 12.65 & 0.0009 & 0.004 & 0.876 & 0.008 \\
\hline & $\mathrm{F}$ & 0.623 & 0.001 & 0.004 & 0.978 & 0.0005 & 0.001 & 0.375 & 0.002 \\
\hline & $\mathrm{R}$ & 1.370 & 0.006 & 0.003 & -0.170 & 0.00002 & 0.0001 & 0.092 & 0.002 \\
\hline & S & 0.160 & 0.006 & 0.003 & -0.266 & 0.001 & 0.0002 & 0.0 & -0.00003 \\
\hline
\end{tabular}

The semi-isocaloric model was set up in a similar manner as the preceding models. Variables represented the number of calories of each food group that would need to be consumed to fill nutrient gaps and their corresponding number values, listed in Table 3-4, represented the amount of each nutrient provided per calorie of each food group, minus the amount of each nutrient provided in half a calorie of fortified maize meal. For example, one calorie of leafy greens provided $12.91 \mu \mathrm{g}$ RE vitamin A and $1 / 2$ calorie of maize meal provided $0.266 \mu \mathrm{g} \mathrm{RE}$, so the total amount of vitamin A provided in each calorie of leafy greens in the semi-isocaloric model was $12.65 \mu \mathrm{g} R E$. The objective function minimized the total number of calories provided. Limits, equivalent to 
those set in the previous model, were imposed on each food group so that leafy greens did not exceed $105 \mathrm{kcal}$, fruits did not exceed $300 \mathrm{kcal}$, roots and tubers did not exceed $110 \mathrm{kcal}$, and seeds, nuts, and grains did not exceed $380 \mathrm{kcal}$. 


\section{CHAPTER 4}

\section{RESULTS}

\subsection{Diet}

Average nutrient intakes, adjusted to reflect estimated post-fortification levels, and comparisons with the EAR are provided in Table 4-1. More than half the women consumed less than the EAR for calcium, zinc, copper, vitamin A, thiamin, riboflavin, vitamin $\mathrm{B}_{6}$, vitamin $\mathrm{B}_{12}$, vitamin $\mathrm{C}$, and vitamin $\mathrm{D}$. The amount of each nutrient required to meet the needs of $50 \%$ and $75 \%$ of women are listed in Table 4-2.

Table 4-1. Summary of adjusted first quartile, median, and third quartile nutrient intake, Estimated Average Requirements, and the percentage of women consuming less than the EAR. $n=142$ women

\begin{tabular}{|c|c|c|c|c|c|}
\hline & Q1 & Median & Q3 & EAR & $\%$ below EAR \\
\hline Energy (kcal) & 1564 & 1918 & 2285 & & \\
\hline Protein $(\mathrm{g})$ & 33.5 & 43.7 & 53.8 & & \\
\hline Fat $(\mathrm{g})$ & 44.5 & 54.2 & 67.3 & & \\
\hline Carbohydrate (g) & 237 & 275 & 348 & & \\
\hline Calcium (mg) & 116 & 239 & 324 & $1000^{\dagger}$ & 100 \\
\hline Iron (mg) & 12.7 & 14.1 & 15.8 & 6.5 & 0 \\
\hline Zinc (mg) & 6.62 & 7.99 & 9.17 & 10.4 & 87 \\
\hline Magnesium (mg) & 207 & 276 & 331 & 225 & 35 \\
\hline Phosphorus (mg) & 545 & 737 & 855 & 580 & 30 \\
\hline Copper (mg) & 0.76 & 0.91 & 1.13 & 1.0 & 58 \\
\hline Vitamin A $(\mu \mathrm{g} R E)$ & 419 & 511 & 583 & 850 & 93 \\
\hline Thiamin (mg) & 0.90 & 1.09 & 1.40 & 1.2 & 56 \\
\hline Riboflavin (mg) & 0.66 & 0.74 & 0.85 & 1.3 & 94 \\
\hline Niacin (mg) & 11.39 & 13.96 & 16.67 & 13 & 39 \\
\hline Vitamin $B_{6}(\mathrm{mg})$ & 1.21 & 1.41 & 1.56 & 1.7 & 83 \\
\hline Folate $(\mu \mathrm{g})$ & 410 & 472 & 540 & 450 & 50 \\
\hline $\operatorname{Vitamin~}_{12}(\mathrm{mg})$ & 0.15 & 0.70 & 1.74 & 2.4 & 82 \\
\hline Vitamin C (mg) & 17.1 & 29.4 & 50.8 & 70 & 86 \\
\hline Vitamin D $(\mu \mathrm{g})$ & 0.27 & 0.91 & 1.96 & 5.0 & 96 \\
\hline Vitamin E (mg) & 17.7 & 23.7 & 27.7 & 10.0 & 7 \\
\hline
\end{tabular}

$\nmid$ No EAR is available for calcium, so the Adequate Intake (AI) is used here 
Table 4-2. The amount of nutrients needed to meet the needs of $50 \%$ and $75 \%$ of lactating women in KwaZulu-Natal

\begin{tabular}{lcc}
\hline & \multicolumn{2}{c}{ Nutrient gaps } \\
\cline { 2 - 3 } & $50 \%$ & $75 \%$ \\
\hline Calcium $(\mathrm{mg})$ & 761 & 884 \\
Zinc $(\mathrm{mg})$ & 2.41 & 3.78 \\
Copper $(\mathrm{mg})$ & 0.09 & 0.24 \\
Vitamin A $(\mu \mathrm{gg} \mathrm{RE})$ & 339 & 431 \\
Thiamin $(\mathrm{mg})$ & 0.11 & 0.30 \\
Riboflavin $(\mathrm{mg})$ & 0.56 & 0.64 \\
Folate $(\mu \mathrm{g})$ & 0.0 & 40.0 \\
Vitamin C $(\mathrm{mg})$ & 40.6 & 52.9 \\
Vitamin $\mathrm{B}_{6}(\mathrm{mg})$ & 0.29 & 0.49 \\
\hline
\end{tabular}

\subsection{Nutrient profile of wild edible plants}

A non-exhaustive list and brief description of wild edible plants that grow in

KwaZulu-Natal can be found in Appendix B. Their nutrient profiles are listed in

Appendix C. Composite nutrient profiles for a 100g sample of each food group are listed

in Table 4-3.

Table 4-3. Composite nutrient profiles of wild edible plant food groups per $100 \mathrm{~g}$

\begin{tabular}{|c|c|c|c|c|}
\hline & Leafy vegetables & Fruit & Roots and tubers & Seeds, nuts, grains \\
\hline Energy (kcal) & 41.9 & 79.6 & 73.9 & 377.8 \\
\hline Protein $(g)$ & 3.6 & 1.6 & 2.4 & 16.5 \\
\hline Fat $(\mathrm{g})$ & 0.6 & 0.8 & 0.2 & 18.6 \\
\hline Carbohydrate (g) & 5.8 & 16.4 & 15.5 & 35.9 \\
\hline Calcium (mg) & 246 & 50 & 102 & 63 \\
\hline Iron $(\mathrm{mg})$ & 5.9 & 1.5 & 1.0 & 4.3 \\
\hline Zinc (mg) & 1.2 & 0.3 & 0.6 & 3.1 \\
\hline Magnesium (mg) & 101 & 35 & 51 & 206 \\
\hline Phosphorus (mg) & 60.8 & 37.8 & 44.1 & 335 \\
\hline Copper (mg) & 0.3 & 0.3 & 0.2 & 1.2 \\
\hline Vitamin A ( $\mu$ g RE) & 541 & 99 & $2.0^{\dagger}$ & $119^{\dagger}$ \\
\hline Thiamin (mg) & 0.06 & 0.07 & 0.05 & 0.55 \\
\hline Riboflavin (mg) & 0.17 & 0.06 & 0.03 & 0.16 \\
\hline Niacin (mg) & 0.78 & 0.72 & 0.47 & 1.61 \\
\hline Folate $(\mu \mathrm{g})$ & 57 & $32^{\dagger}$ & $14.2^{\dagger}$ & $35^{\dagger}$ \\
\hline Vitamin C (mg) & 36.7 & 29.8 & 6.8 & $0^{\dagger}$ \\
\hline Vitamin $\mathrm{B}_{6}(\mathrm{mg})$ & $0.27^{\dagger}$ & $0.12^{\dagger}$ & $0.21^{\dagger}$ & $0.63^{\dagger}$ \\
\hline
\end{tabular}

$\dagger$ Nutrient levels from USDA's food group composites (Marcoe et al., 2006)

Individual nutrient levels provided by Odhav et al., 2007; USDA, 2005; and Wehmeyer, 1986 


\subsection{Optimizing intake}

The optimal blends of wild edible plant food groups that need to be consumed to meet the nutrient needs of $50 \%$ and $75 \%$ of lactating women while minimizing total grams or calories provided are summarized in Table 4-4. When minimizing the total number of grams that are consumed, the nutrient needs of $50 \%$ of lactating women can be met by consuming an additional $332 \mathrm{kcal}$ composed of $250 \mathrm{~g}$ of leafy vegetables (equivalent to 8 cups raw or $1 \frac{1}{2}$ cup cooked), $150 \mathrm{~g}$ of fruit (equivalent to $1 \frac{1}{2} 2$ cups or 2 medium peach sized fruits), $59 \mathrm{~g}$ of roots and tubers (equivalent to half a potato), and $17 \mathrm{~g}$ of seeds, nuts, and grains (equivalent to $1 / 10$ cup raw grain or $3 / 4 \mathrm{oz}$ nuts). The same mix will also meet the needs of $75 \%$ of women for all nutrients except calcium and riboflavin. To fully meet all needs of $75 \%$ of women, $250 \mathrm{~g}$ of leafy greens, $150 \mathrm{~g}$ of fruit, $150 \mathrm{~g}$ of roots and tubers, and $66 \mathrm{~g}$ of seeds, nuts, and grains would be needed, providing $584 \mathrm{kcal}$. The average energy intake of $1918 \mathrm{kcal}$ in this population is in accordance with recommendations that lactating women who are not physically active consume $1900 \mathrm{kcal}$ per day (Brown, 2008), making the additional calories provided by either mixture potentially excessive and inappropriate to be recommended for a population characterized by high rates of obesity.

Table 4-4. Optimum blends of wild edible plant food groups that need to be consumed to meet the nutrient needs of $50 \%$ and $75 \%$ of lactating women while minimizing total grams or calories provided

\begin{tabular}{lcc|cc}
\hline & \multicolumn{2}{c|}{ Minimizing total grams } & \multicolumn{2}{c}{ Minimizing total energy } \\
\cline { 2 - 5 } & $50 \%$ & $75 \%$ & $50 \%$ & $75 \%$ \\
\hline Leafy greens $(\mathrm{g})$ & 250 & 250 & 250 & 250 \\
Fruit $(\mathrm{g})$ & 150 & 150 & 176 & 276 \\
Roots and tubers $(\mathrm{g})$ & 59 & 150 & 55 & 127 \\
Seeds/nuts/grains $(\mathrm{g})$ & 17 & 66 & 0 & 0 \\
Total energy $(\mathrm{kcal})$ & 332 & 584 & 286 & 419 \\
\hline
\end{tabular}


When minimizing the total amount of energy provided, the nutrient needs of 50\% of lactating women can be met by consuming $250 \mathrm{~g}$ of leafy greens, $176 \mathrm{~g}$ of fruit, and $55 \mathrm{~g}$ of roots and tubers in addition to the current diet. This blend will increase energy intake by $286 \mathrm{kcal}$ and meet the needs of $75 \%$ of women for all nutrients except calcium, thiamin, and riboflavin. To fully meet the needs of $75 \%$ of women while minimizing calories, $250 \mathrm{~g}$ leafy greens, $276 \mathrm{~g}$ fruit, and $127 \mathrm{~g}$ of roots and tubers would need to be consumed in addition to the current diet, providing 419 additional calories (Table 4-4). Although the amount of energy provided by these models is lower than in the models minimizing volume, the additional calories may still be higher than should be recommended for this population.

A semi-isocaloric model in which half of the additional calories provided by wild edible plants replace an equivalent amount of maize meal provides a slightly more reasonable and simpler mixture (Table 4-5). The needs of 50\% of women can be met through an additional $192 \mathrm{kcal}$, made up of $250 \mathrm{~g}$ of leafy vegetables (equivalent to 8 cups raw or $1 \frac{1 / 2}{2}$ cups cooked) and $349 \mathrm{~g}$ of fruit (equivalent to $2^{1 / 4}$ cups or 4 medium peaches), replacing $54 \mathrm{~g}$ of maize meal (equivalent to $1 / 2$ cup raw). The total amounts of nutrients provided by this blend are listed in Table 4-6. How this blend is predicted to impact the overall diet is shown in Figure 4-1. The amount of calories this blend would add to the diet is acceptable, particularly if levels of physical activity increased in association with collecting food. The same blend will meet the needs of $75 \%$ of women for all nutrients except calcium, zinc, thiamin, and riboflavin. To fully meet all requirements of $75 \%$ of women, $250 \mathrm{~g}$ of leafy greens, $375 \mathrm{~g}$ fruit, $22 \mathrm{~g}$ of roots and tubers, and $97 \mathrm{~g}$ of seeds, nuts, 
and grains would be needed, replacing $112 \mathrm{~g}$ of maize and providing 397 additional

calories.

Table 4-5. Optimal food group composition of wild edible plants that need to be consumed to meet the nutrient needs of $50 \%$ and $75 \%$ of lactating women when using a semi-isocaloric model in which half the calories provided by the wild edible plants replace an equivalent number of calories of fortified maize meal

\begin{tabular}{lcc}
\hline & $50 \%$ & $75 \%$ \\
\hline Leafy greens $(\mathrm{g})$ & 250 & 250 \\
Fruit $(\mathrm{g})$ & 349 & 375 \\
Roots and tubers $(\mathrm{g})$ & 0 & 22 \\
Seeds/nuts/grains $(\mathrm{g})$ & 0 & 97 \\
Maize meal replaced $(\mathrm{g})$ & 54 & 112 \\
Net energy (kcal) & 192 & 397 \\
\hline
\end{tabular}

Table 4-6. Nutrient composition of optimal blend of wild edible plants to meet the needs of $50 \%$ of lactating women using a semi-isocaloric model, where half of additional calories are replacing the nutrients in an equivalent amount of maize meal, and the potential impact on total diet

\begin{tabular}{lcccc|c}
\hline & $\begin{array}{c}\text { Leaves } \\
(250 \mathrm{~g})\end{array}$ & $\begin{array}{c}\text { Fruit } \\
(349 \mathrm{~g})\end{array}$ & $\begin{array}{c}\text { Maize } \\
(54 \mathrm{~g})^{\dagger}\end{array}$ & $\begin{array}{c}\text { Net Total } \\
(545 \mathrm{~g})\end{array}$ & Diet Total \\
\hline Energy $(\mathrm{kcal})$ & 105 & 278 & 192 & 192 & 2110 \\
Protein $(\mathrm{g})$ & 9.0 & 5.7 & 4.6 & 10.0 & 53.7 \\
Fat $(\mathrm{g})$ & 1.4 & 2.8 & 0.7 & 3.5 & 57.7 \\
Carbohydrate $(\mathrm{g})$ & 14.5 & 57.3 & 40.2 & 31.6 & 306 \\
Calcium $(\mathrm{mg})$ & 616.6 & 174.9 & 2.3 & 789.2 & 1028 \\
Iron $(\mathrm{mg})$ & 14.8 & 5.2 & 2.0 & 18.0 & 32.0 \\
Zinc $(\mathrm{mg})$ & 2.9 & 1.1 & 1.0 & 3.0 & 11.0 \\
Magnesium $(\mathrm{mg})$ & 254 & 122 & 41 & 335 & 611 \\
Phosphorus $(\mathrm{mg})$ & 152 & 132 & 94 & 190 & 927 \\
Copper $(\mathrm{mg})$ & 0.86 & 1.06 & 0.05 & 1.88 & 2.78 \\
Vitamin A $(\mu \mathrm{g} \mathrm{RE})$ & 1356 & 346 & 102 & 1600 & 2111 \\
Thiamin $(\mathrm{mg})$ & 0.14 & 0.25 & 0.17 & 0.22 & 1.31 \\
Riboflavin $(\mathrm{mg})$ & 0.43 & 0.23 & 0.10 & 0.56 & 1.30 \\
Niacin $(\mathrm{mg})$ & 1.97 & 2.51 & 1.61 & 2.87 & 16.82 \\
Folate $(\mu \mathrm{g})$ & 143 & 91 & 102 & 131 & 603 \\
Vitamin C $(\mathrm{mg})$ & 91.9 & 104.2 & 0.0 & 196.1 & 225.5 \\
Vitamin $\mathrm{B}_{6}(\mathrm{mg})$ & 0.87 & 0.60 & 0.22 & 1.25 & 2.66 \\
\hline
\end{tabular}

$\dagger$ Amount eliminated from the diet 


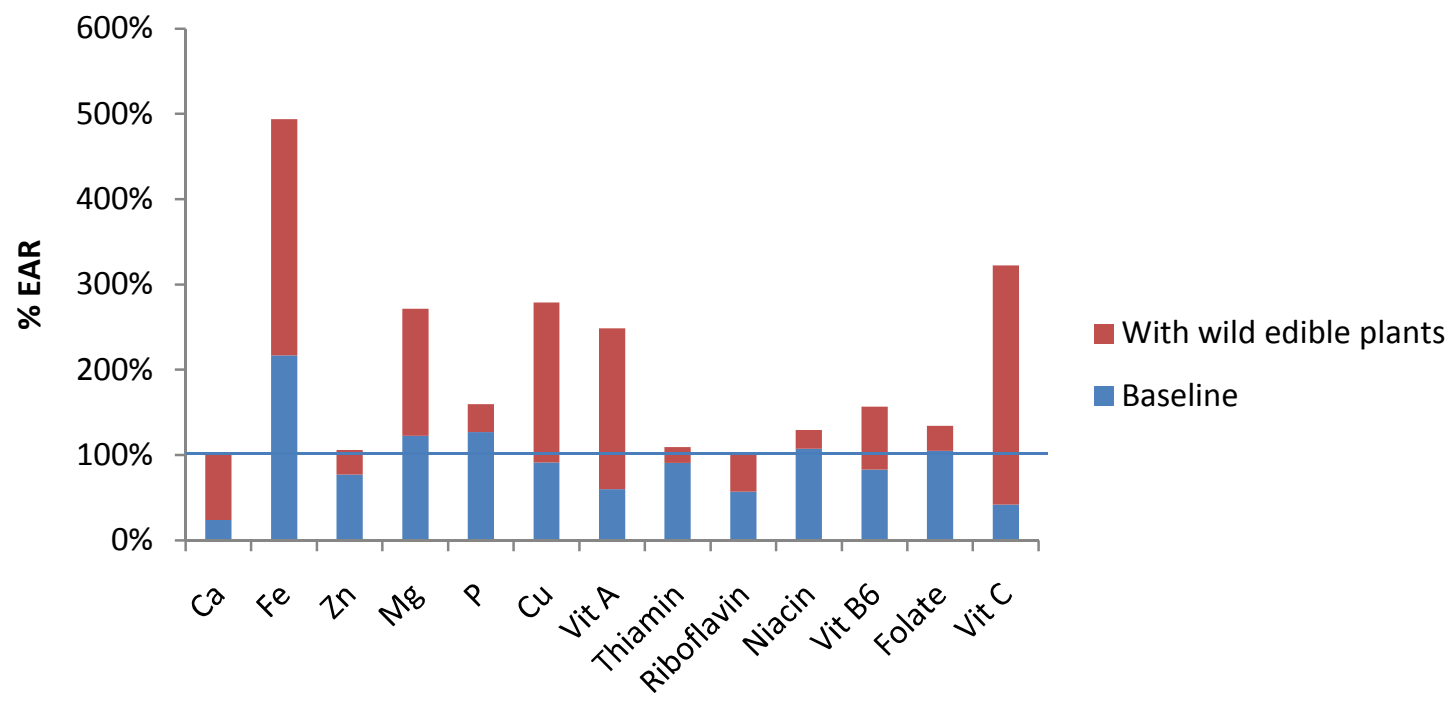

Figure 4-1. Median percentage of the Estimated Average Requirement for micronutrients currently consumed and predicted improvement if $250 \mathrm{~g}$ wild leafy vegetable and $349 \mathrm{~g}$ fruit are eaten, replacing $54 \mathrm{~g}$ of maize meal.

Note $100 \%$ EAR meets the nutrient needs of $50 \%$ of individuals in a population 


\section{CHAPTER 5}

\section{DISCUSSION}

Before fortification in South Africa, lactating women in the present study consumed adequate amounts of iron, magnesium, phosphorus, and vitamin E with low intakes of calcium, zinc, copper, thiamin, riboflavin, niacin, folate, and vitamins $\mathrm{A}, \mathrm{B}_{6}$, $\mathrm{B}_{12}, \mathrm{C}$, and D. Intakes of iron, zinc, vitamin $\mathrm{A}$, thiamin, riboflavin, niacin, folate, and vitamin $\mathrm{B}_{6}$ significantly increased following fortification of maize meal and wheat flour, but intakes of all fortified nutrients except iron, niacin, and folate remained below recommended levels for lactating women. Linear programming models were developed showing how diet quality of this population could be improved by consuming wild edible plants available in the study area either in addition to the current diet or partially replacing maize meal.

While minimizing the total mass of additional food that would need to be eaten, consuming $250 \mathrm{~g}$ of leafy vegetables, $150 \mathrm{~g}$ fruit, $59 \mathrm{~g}$ of roots and tubers, and $17 \mathrm{~g}$ of seeds, nuts, and grains can meet the micronutrient needs of $50 \%$ of lactating women without changing any other aspects of the diet, but this blend will increase energy intake by $332 \mathrm{kcal}$, which may be excessive in a population characterized by high rates of obesity (Puoane et al., 2002). If additional calories are minimized rather than by weight, the micronutrient needs of $50 \%$ of lactating women can be met through the additional consumption of $250 \mathrm{~g}$ of leafy greens, $176 \mathrm{~g}$ of fruit, and $55 \mathrm{~g}$ of roots and tubers. This blend increases energy consumption by $286 \mathrm{kcal}$, which is still higher than desirable for this population. The simpler semi-isocaloric model including $250 \mathrm{~g}$ of leafy green 
vegetables and $349 \mathrm{~g}$ of fruit, replacing $54 \mathrm{~g}$ of maize meal and providing only 192 additional calories, is therefore recommended.

Several nutrients are provided by the recommended blend of wild edible plants in very high amounts. Iron, at $32 \mathrm{mg}$, exceeded the EAR for lactating women by nearly $400 \%$. This level, however, is only slightly above the recommended dietary allowance (RDA) for pregnant women $(27 \mathrm{mg})$ and is well below the established tolerable upper intake level (UL) for lactation set at 45mg (NIH, 2007). Iron from plant sources also tends to have low bioavailability (Akwaowo et al., 2000). This amount, therefore, is not likely to have detrimental effects. The amount of magnesium provided $(611 \mathrm{mg})$ exceeded the EAR by 170\%. There is no UL for dietary magnesium (NIH, 2009), but excessive intake may be problematic for individuals with impaired renal function (Gropper et al., 2009). Copper, vitamin A, and vitamin C also exceeded the EAR by $178 \%, 148 \%$ and $222 \%$ respectively, but all amounts were well below the ULs and not likely to have negative effects (Gropper et al., 2009).

The recommended amount of wild edible plants is higher than the national recommendation for fruit and vegetable consumption of 400 total grams per day and much higher than the 141g that are typically consumed in rural areas (Maunder and Meaker, 2007). Micronutrient needs for lactating women are higher than for any other segment of the population (Picciano, 2003), so recommendations for other groups may be able to include lower amounts of wild edible plants. Such an extreme change in eating patterns will be difficult to bring about. An intervention program encouraging the increased consumption of wild edible plants will have the greatest chance of success if nutrition education is incorporated (Faber et al., 2002a; Walsh et al., 2002). Care must 
also be taken to not increase negative perceptions of these foods by targeting interventions only towards the poor and individuals with HIV (Faber et al., 2010; Vorster et al., 2007b). Presenting the idea in a way that will appeal to those who would like to return to traditional ways and those who want to be more modern will also be an asset (Vincent, 2006). Maintaining sustainability will be aided by encouraging cultivation of these plants in home and community gardens (Kaschula and Arbuckle, 2007; Lewu and Mavengahama, 2010; Vorster et al., 2007a).

Average micronutrient intakes of the women in the present study were somewhat different than what is seen nationally. National dietary surveys of adults have not been performed in South Africa, but a secondary analysis of data collected on 1726 women between 1983 and 2000 suggests that women in South Africa, before fortification, consumed low levels of calcium (410.3 mg), iron ( $8.8 \mathrm{mg})$, folate $(231.4 \mu \mathrm{g})$, and vitamin $\mathrm{B}_{6}(0.9 \mathrm{mg})$, while consuming adequate levels of vitamins $\mathrm{A}$ (759.2 RE), C (59.1 mg), $\mathrm{B}_{12}(4.8 \mu \mathrm{g}), \mathrm{E}(7.1 \mathrm{mg})$ and zinc $(8.4 \mathrm{mg})$, with intakes being lower in rural compared to urban areas (Steyn et al., 2007). Pre-fortification intakes in the present study were lower for all nutrients except for vitamin $\mathrm{E}$ and adequate during lactation for only iron and vitamin E. These differences are likely due to regional variation in diet patterns. Faber and Wenhold (2007) found that rates of vitamin A deficiency in young children in KwaZulu-Natal were among the highest in the country at $38 \%$, while rates of anemia were among the lowest at $10.4 \%$, which support the idea of regional variation in intake. Such differences highlight the need to collect region- and population-specific dietary data so that nutrition interventions can be specifically tailored to meet the needs of the target population. 
Fortification of maize and wheat products significantly increased consumption of iron, zinc, vitamin $\mathrm{A}$, thiamin, riboflavin, niacin, vitamin $\mathrm{B}_{6}$, and folate in this study, but median consumption of only iron, niacin, and folate increased to the EAR or higher. Although consumption of many nutrients remains inadequate, improvements brought about by fortification will allow other intervention programs, such as the increased consumption of wild edible plants, to be more successful because the required change is smaller.

One of the limitations of this study is the overall poor quality of data on the nutrient composition of wild edible plants. There is a general lack of information on the chemical composition and nutritional values of wild edible plants in South Africa (van der Walt et al., 2009a). Recent interest in the value of wild leafy green vegetables has led to improved knowledge of the nutrient composition of the most common types (Faber et al., 2002b; Modi et al., 2006; Odhav et al., 2007), but less commonly consumed greens, as well as fruits, roots, tubers, seeds, nuts, and grains, continue to be neglected. Most nutrient composition studies also do not take into account local soil and environmental conditions that might be influential (Lewu and Mavengahama, 2010). Mineral content of plants is a reflection of the environment in which they were grown, with soil type, fertilizer use, and climate exerting the greatest influence (Bear et al., 1948). Improved knowledge of the nutrient content of wild plants, taking into account local environmental conditions and agricultural practices, will allow more accurate estimations of how these foods can improve micronutrient intake.

A second limitation, related to the first, was the use of the USDA's composite nutrient profiles (Marcoe et al., 2006) for food groups when no other information was 
available. These values were based on foods typically consumed in the United States and may not reflect accurate values of wild plants in South Africa. Wild plants, however, have been repeatedly found to have higher nutrient levels than cultivated varieties (Afolayan and Jimoh, 2009; Mnkeni et al., 2007; van der Walt et al., 2009a). A comparison of the composite nutrient values for wild leafy green vegetables used in this study with the values for the dark green vegetable food group created by the USDA shows that more than half the values are higher for the wild greens (Table 5-1). It is likely, then, that these borrowed values may be under- rather than over-estimates of true wild plant composition.

Table 5-1. Comparison of the composite nutrient values for leafy green vegetables for wild edible plants used in this study and the values created by the USDA

\begin{tabular}{lccc}
\hline & Wild edible plants & USDA & Difference \\
\hline Calcium $(\mathrm{mg})$ & 246 & 105 & 141 \\
Iron $(\mathrm{mg})$ & 5.9 & 2.1 & 3.8 \\
Zinc $(\mathrm{mg})$ & 1.2 & 0.63 & 0.57 \\
Magnesium (mg) & 101 & 52.5 & 48.5 \\
Phosphorus (mg) & 60.8 & 81.9 & -21.1 \\
Copper (mg0 & 0.3 & 0.15 & 0.15 \\
Vitamin A ( $\mu \mathrm{g}$ RE) & 541 & 351 & 190 \\
Thiamin $(\mathrm{mg})$ & 0.06 & 0.11 & -0.05 \\
Riboflavin $(\mathrm{mg})$ & 0.17 & 0.21 & -0.04 \\
Niacin $(\mathrm{mg})$ & 0.78 & 0.84 & -0.06 \\
Vitamin C $(\mathrm{mg})$ & 36.7 & 63 & -26.3 \\
\hline
\end{tabular}

Anti-nutrients and bioavailability of micronutrients is a concern in plant-based diets. Substances such as phytic acid, lecitins, tannins, saponins, and others, can reduce the availability of certain nutrients, particularly minerals, and impair growth (Shahidi, 1997). High intakes of tannic acid have been associated with increased rates of cancer, poor protein utilization, and liver and kidney toxicity. High phytic acid intake can 
decrease iron absorption by 4-5 fold (Akwaowo et al., 2000). On the other hand, these same substances, in low doses, have also been shown to reduce blood glucose and cholesterol levels and reduce cancer risks (Shahidi, 1997). Cooking and processing foods is believed to eliminate most of the harmful effects that may be caused by anti-nutrients consumed in high concentrations (Akwaowo et al., 2000). Analyses of several different African wild leafy vegetables have revealed that anti-nutrient levels in these plants are lower than observed in many other non-conventional leafy greens and that consumption would not cause any negative effects (Afolayan and Jimoh, 2009; Wallace et al., 1998). Additional research on the anti-nutrient content of wild edible plants in South Africa and both the beneficial and negative effects they could have if consumed in recommended amounts is needed.

The availability of wild edible plants varies by season. Leafy vegetables are predominantly available in the rainy season (O'Brien and Peters, 1998). In KwaZuluNatal, wild leafy greens are abundantly available from October to March, being absent only in June and July, South Africa's winter (Modi et al., 2006). Little research has been done on the possibility of extending their growing season, but some of these vegetables have been found growing as weeds in irrigated fields during winter, suggesting that offseason cultivation of wild leafy greens may be possible (Lewu and Mavengahama, 2010). A second approach to extending availability is preserving leafy greens through drying, a technique that many older African rural women have mastered, but that is no longer being practiced by many of the younger generation (Masarirambi et al., 2010), and is not practiced at all in KwaZulu-Natal (Faber et al., 2010). This processing, however, does decrease vitamin content (Masarirambi et al., 2010). Adjustments to recommendations 
may be needed if dried foods are commonly used. Wild fruits can be found throughout the year, but are most abundant and available in the greatest variety between January and August (Fentahun and Hager, 2009). Roots and tubers can also be available year round, but are more so in the wet season (O'Brien and Peters, 1998).

Micronutrients that were consumed in inadequate amounts in the present study that cannot be obtained through increased consumption of wild plants include vitamins $\mathrm{B}_{12}$ and $\mathrm{D}$, which are not typically found in plants. Vitamin $\mathrm{B}_{12}$ is found naturally only in animal products and some nutritional yeasts (NIH, 2010a). Vitamin D is naturally found in few foods, with fatty fish being the best source. Vitamin D can also be synthesized in skin from sunlight exposure, although effectiveness of this process is somewhat reduced with darkly pigmented skin (NIH, 2010b). The collection, cultivation, and sale of wild foods can significantly increase income, as has been seen in other populations (Fleuret, 1979; Misra et al., 2008). It is therefore hoped that increased wild plant consumption will improve economic conditions sufficiently so that more animal based foods can be consumed to meet these requirements.

Benefits of increasing wild edible plant consumption go beyond meeting micronutrient needs. Diseases of the circulatory system are a growing problem in South Africa, accounting for 14\% of deaths in 2004 (SSA, 2006). High rates of fruit and vegetable consumption are associated with decreased risk of major chronic disease and cancer (Fairfield and Fletcher, 2002; Hung et al., 2004; Smith-Warner et al., 2001). Adequate intakes of folate, B vitamins, vitamin E, and carotenoids are also associated with decreased risk of cardiovascular disease and cancer (Fairfield and Fletcher, 2002; Whelton et al., 1997) and higher magnesium, potassium, and calcium intakes can 
decrease blood pressure (Gokah and Gumpo, 2010; Whelton et al., 1997). Fiber consumption can increase resistance to disease by improving the innate immune system, or the physical barrier between pathogens and the body (Bengmark, 2010). Increased physical activity in association with collecting plants could also potentially improve health. An intervention among older adults in South Africa found that twice weekly lowintensity exercise could significantly decrease blood pressure and reduce the burden of disease in that population (Kolbe et al., 1999). 


\section{CHAPTER 6}

\section{CONCLUSION}

Many influences have driven the nutrition transition in South Africa leading to the current health and diet patterns associated with receding famine and degenerative disease. Looking to the past, the healthiest eras in KwaZulu-Natal's history were times when wild plants were eaten, dietary diversity was high, and families were strong. Environmental, political, and economic forces have changed circumstances to a degree that those past conditions cannot be re-created. By understanding these forces, however, a healthier future can be established. Restoring knowledge, use of, and pride in wild edible plants can be an important part of this process. Wild foods are highly nutritious, widely available in great variety, grow well under adverse conditions with minimal care, and are freely available to everyone. Increasing consumption of these foods can improve nutrient status of all individuals and help combat epidemics of both communicable and noncommunicable disease. Other interventions, such as fortification, supplementation, nutrition education, and the encouragement of home and community gardens, also have the potential to help. The greatest impact, however, will be seen if all these programs, including increased wild edible plant consumption, work together. Although such interventions, particularly consumption of wild foods, would provide the most benefit to the poor and individuals with HIV, care must be taken that these groups are not singled out so that negative perceptions of these foods do not increase.

More information will be needed on the nutrient composition of wild edible plants before an effective intervention focusing on their use can be planned. Progress is being 
made in this direction, but less common leafy greens, fruits, roots and tubers, seeds, nuts, and grains continue to be neglected. Greater attention is also needed on how antinutrients in these plants will affect bioavailability of nutrients and general health of the consumer. Seasonality and ways to extend availability of wild plants throughout the year will also need to be taken into consideration. Even with the limited information currently available, it is clear that a reasonable increase in consumption of wild edible plants can have tremendous positive impacts on the health and nutrient status of lactating women in KwaZulu-Natal, which would in turn improve the health and wellbeing of the entire population. 


\section{REFERENCES}

Abramson, J.H., B. Gampel, N. Scotch, and C. Slome. 1960. Diet and serum protein levels of urban Zulu adults. British Journal of Preventive \& Social Medicine $14: 190-195$.

Afolayan, A.J., and F.O. Jimoh. 2009. Nutritional quality of some wild leafy vegetables in South Africa. International Journal of Food Science and Nutrition 60:424-431.

Aguero, J., M.R. Carter, and J. May. 2007. Poverty and inequality in the first decade of South Africa's democracy: what can be learnt from panel data fro KwaZuluNatal? Journal of African Economies 16:782-812.

Akwaowo, E.U., B.A. Ndon, and E.U. Etuk. 2000. Minerals and antinutrients in fluted pumpkin (Telfairia occidentalis Hookf.). Food Chemistry 70:235-240.

Aphane, J., M.J. Chadha, and M.O. Oluoch. 2002. Increasing the consumption of micronutrient-rich foods through production and promotion of indigenous foods FAO-AVRDC International Workshop Proceedings, Arusha, Tanzania.

Atkins, K.E. 1993. The Moon Is Dead! Give Us Our Money! The Cultural Origins of an African Work Ethic, Natal, South Africa, 1843-1900 Heinemann, Portsmouth, NH.

Backwell, L., F. d'Errico, and L. Wadley. 2008. Middle Stone Age bone tools from the Howiesons Poort layers, Sibudu Cave, South Africa. Journal of Archaeological Science 35:1566-1580.

Ballard, C. 1986a. The repercussions of rinderpest: Cattle plague and peasant decline in colonial Natal. The International Journal of African Historical Studies 19:421450.

Ballard, C. 1986b. Drought and economic distress: South Africa in the 1800s. Journal of Interdisciplinary History XVII:359-378.

Bates, C.J., A.M. Prentice, and A.A. Paul. 1994. Seasonal variations in vitamins A, C, riboflavin and folate intakes and status of pregnant and lactating women in a rural Gambian community: Some possible implications. European Journal of Clinical Nutrition 48:660-668.

Beall, J., S. Mkhize, and S. Vawda. 2005. Emergent democracy and 'resurgent' tradition: Institutions, chieftaincy and transition in KwaZulu-Natal. Journal of Southern African Studies 31:755-771.

Bear, F.E., S.J. Toth, and A.L. Prince. 1948. Variation in mineral composition of vegetables. Soil Science Society of America Proceedings 13:380-384.

Beisel, W. 1996. Nutrition in pediatric HIV infection: Setting the research agenda. Nutrition and immune function: overview. Journal of Nutrition 126:2611-2615.

Bengmark, S. 2010. Pre-, pro-, synbiotics and human health. Food Technology and Biotechnology 48:464-475.

Bentley, G.R., A.M. Harrigan, and P.T. Ellison. 1998. Dietary composition and ovarian function among Lese horticulturalist women of the Ituri Forest, Democratic Republic of Congo. European Journal of Clinical Nutrition 52:261-270.

Bernstein, H. 1996. South Africa's agrarian question: Extreme and exceptional? Journal of Peasant Studies 23:1-52. 
Bharucha, Z., and J. Pretty. 2010. The roles and values of wild foods in agricultural systems. Philosophical Transactions of the Royal Society B 365:2913-2926.

Bingham, S.A., C. Gill, A. Welch, K. Day, A. Cassidy, K.T. Khaw, M.J. Sneyd, T.J.A. Key, L. Roe, and N.E. Day. 1994. Comparison of dietary assessment methods in nutritional epidemiology: Weighed records v. $24 \mathrm{~h}$ recalls, food-frequency questionnaires and estimated-diet records. British Journal of Nutrition 72:619643.

Bland, R.M., H.M. Coovadia, A. Coutsoudis, N.C. Rollins, and M.L. Newell. 2010. Cohort profile: Mamenengane or the Africa centre vertical transmission study. International Journal of Epidemiology 39:351-360.

Bousman, C.B. 2005. Coping with risk: Later stone age technological strategies at Blydefontein Rock Shelter, South Africa. Journal of Anthropological Archaeology 24:193-226.

Brenton, B.P., and R.R. Paine. 2007. Reevaluating the health and nutritional status of maize-dependent populations: Evidence for the impact of pellagra on human skeletons from South Africa. Ecology of Food and Nutrition 46:345-360.

Brown, J.E. 2008. Nutrition Through the Life Cycle. 3rd ed. Thomson Wadsworth, Belmont, CA.

Campbell, C. 1992. Learning to kill? Masculinity, the family and violence in Natal. Journal of Southern African Studies 18:614-628.

Carlson, A., M. Lino, W.Y. Juan, K. Hanson, and P.P. Basiotis. 2006. Thrifty food plan, 2006. USDA Center for Nutrition Policy and Promotion.

CDC. 2010. Basic information about HIV and AIDS. Available by Centers for Disease Control and Prevention www.cdc.gov/hiv/topics/basic/index.htm.

Cecchini, M., F. Sassi, J.A. Lauer, Y.Y. Lee, V. Guajardo-Barron, and D. Chisholm. 2010. Tackling of unhealthy diets, physical inactivity, and obesity: Health effects and cost-effectiveness. Lancet 376:1775-1784.

Chandra, R.K. 2002. Nutrition and the immune system from birth to old age. European Journal of Clinical Nutrition 56:S73-S76.

Charlton, K.E., P. Brewitt, and L.T. Bourne. 2004. Sources and credibility of nutrition information among black urban South African women, with a focus on messages related to obesity. Public Health Nutrition 7:801-811.

Chazan, M., and A. Whiteside. 2007. The making of vulnerabilities: Understanding the differentiated effects of HIV and AIDS among street traders in Warwick Junction, Durban, South Africa. Ajar-African Journal of Aids Research 6:165-173.

CHU. 1997. An evaluation of South Africa's Primary School Nutrition Programme. Child Health Unit, Health Systems Trust, Durban.

Clover, J., and S. Eriksen. 2009. The effects of land tenure change on sustainability: Human security and environmental change in southern African savannas. Environmental Science \& Policy 12:53-70.

Coovadia, H., R. Jewkes, P. Barron, D. Sanders, and D. McIntyre. 2009. The health and health system of South Africa: Historical roots of current public health challenges. www.thelancet.com 374:817-834.

Crane, W. 2006. Biodiversity conservation and land rights in South Africa: Whither the farm dwellers? Geoforum 37:1035-1045. 
Cunningham, S.A., I.T. Elo, K. Herbst, and V. Hosegood. 2010. Prenatal development in rural South Africa: Relationship between birth weight and access to fathers and grandparents. Population Studies-a Journal of Demography 64:229-246.

Deflem, M. 1999. Warfare, political leadership, and state formation: The case of the Zulu Kingdom, 1808-1879. Ethnology 38:371-391.

Delius, P. 2010. Recapturing captives and conversations with 'cannibals': In pursuit of a neglected stratum in South African history. Journal of Southern African Studies 36:7-23.

Dewar, G., D. Halkett, T. Hart, J. Orton, and J. Sealy. 2006. Implications of a mass kill site of springbok (Antidorcas marsupialis) in South Africa: hunting practices, gender relations, and sharing in the Later Stone Age. Journal of Archaeological Science 33:1266-1275.

Dodd, K.W., P.M. Guenther, L.S. Freedman, A.F. Subar, V. Kipnis, D. Midthune, J.A. Tooze, and S.M. Krebs-Smith. 2006. Statistical methods for estimating usual intake of nutrients and foods: A review of the theory. Journal of the American Dietetic Association 106:1640-1650.

DOH. 1993. Primary school nutrition programme (PSNP). National framework and operational guide. Department of Health, Pretoria.

Eason, A.M. 2009. 'All things to all people to save some': Salvation Army missionary work among the Zulus of victorian Natal. Journal of Southern African Studies 35:7-27.

Eeley, H.A.C., M.J. Lawes, and S.E. Piper. 1999. The influence of climate change on the distribution of indigenous forest in KwaZulu-Natal, South Africa. Journal of Biogeography 26:595-617.

Faber, M., and F. Wenhold. 2007. Nutrition in contemporary South Africa. Water SA 33:393-400.

Faber, M., V.B. Jogessar, and A.J.S. Benade. 2001. Nutritional status and dietary intakes of children aged 2-5 years and their caregivers in a rural South African community. International Journal of Food Sciences and Nutrition 52:401-411.

Faber, M., S.L. Venter, and A.J.S. Benade. 2002a. Increased vitamin A intake in children aged 2-5 years through targeted home-gardens in a rural South African community. Public Health Nutrition 5:11-16.

Faber, M., M.A.S. Phungula, S.L. Venter, M.A. Dhansay, and A.J.S. Benade. 2002b. Home gardens focusing on the production of yellow and dark-green leafy vegetables increase the serum retinol concentrations of 2-5-y-old children in South Africa. American Journal of Clinical Nutrition 76:1048-1054.

Faber, M., A. Oelofse, P.J. Van Jaarsveld, F.A.M. Wenhold, and W.S. Jansen van Rensburg. 2010. African leafy vegetables consumed by households in the Limpopo and KwaZulu-Natal provinces in South Africa. South African Journal of Clinical Nutrition 23:30-38.

Fairfield, K.M., and R.H. Fletcher. 2002. Vitamins for chronic disease prevention in adults. JAMA 287:3116-3126.

FAO. 1982. Apartheid, Poverty and Malnutrition FAO Economic and Social Development Paper 24. FAO, Rome. 
Fawzi, W. 2000. Nutritional factors and vertical transmission of HIV-1 - Epidemiology and potential mechanisms, p. 99-114, In A. J. Ammann and A. Rubinstein, eds. Prevention and Treatment of HIV Infection in Infants and Children, Vol. 918. New York Acad Sciences, New York.

Fawzi, W., G. Msamanga, D. Spiegelman, and D. Hunter. 2005. Studies of vitamins and minerals and HIV transmission and disease progression. Journal of Nutrition 135:938-944.

Fentahun, M.T., and H. Hager. 2009. Exploiting locally available resources for food and nutritional security enhancement: Wild fruits diversity, potential and state of exploitation in the Amhara region of Ethiopia. Food Security 1:207-219.

Ferguson, E.L., N. Darmon, A. Briend, and I.M. Premachandra. 2004. Food-based dietary guidelines can be developed and tested using linear programming analysis. The Journal of Nutrition 134:951-957.

Ferguson, E.L., N. Darmon, U. Fahmida, S. Fitriyanti, and T.B. Harper. 2006. Design of optimal food-based complementary feeding recommendations and identification of key "promlem nutrients" using goal programming. The Journal of Nutrition 136:2399-2404.

Ferris, M.C., O.L. Mangasarian, and S.J. Wright. 2007. Linear Programming with MATLAB Society for Industrial and Applied Mathmatics, Philadelphia.

Fleuret, A. 1979. The role of wild foliage plants in the diet: A case study from Lushoto, Tanzania. Ecology of Food and Nutrition 8:87-93.

Francis, M. 2009. Silencing the past: historical and archaeological colonization of the southern San in KwaZulu-Natal, South Africa. Anthropology Southern Africa 32:106-115.

Friis, G.H., and P. Koestel. 2001. HIV and other predictors of serum beta-carotene and retinol in pregnancy: A cross-sectional study in Zimbabwe. American Journal of Clinical Nutrition 73:1058-1065.

Gokah, T.K., and R. Gumpo. 2010. Enabling and empowering-the need for an integrated approach to address hypertension among African adults. Health Education Research 25:510-518.

Goodman, A.H., D.L. Dufour, and G.H. Pelto, (eds.) 2000. Nutritional Anthropology: Biocultural Perspectives on Food and Nutrition, pp. 1-376. Mayfield Publishing Company, Mountain View, CA.

Grinspoon, S.K., and A. Carr. 2005. Cardiovascular risk and body-fat abnormalities in HIV-infected adults. New England Journal of Medicine 352:48-62.

Grinspoon, S.K., C. Grunfeld, D.P. Kotler, J.S. Currier, J.E. Lundgren, M.P. Dube, S.E. Lipshultz, P.Y. Hsue, K. Squires, M. Schambelan, P.W.F. Wilson, K.E.

Yarasheski, C.M. Hadigan, J.H. Stein, and R.H. Eckel. 2008. State of the science conference. Initiative to decrease cardiovascular risk and increase quality of care for patients living with HIV/AIDS executive summary. Circulation 118:198-210.

Grivetti, L.E., and B.M. Ogle. 2000. Value of traditional foods in meeting macro- and micronutrient needs: The wild plant connection. Nutrition Research Reviews 13:31-46.

Gropper, S.S., J.L. Smith, and J.L. Groff. 2009. Advanced Nutrition and Human Metabolism. 5th ed. Wadsworth, Cengage Learning, Belmont, CA. 
Gunner, L. 2005. Remapping land and remaking culture: Memory and landscape in 20thcentury South Africa. Journal of Historical Geography 31:281-295.

Haag, F., and F. Hajdu. 2005. Perspectives on local environmental security, exemplified by a rural South African village. Environmental Management 36:483-494.

Hall, S., and S. Chirikure. 2008. Herders, Farmers, and Metallurgists of South Africa, pp. 66-71 Encyclopedia of archaelogy, Vol. 1A. Academic Press, Amsterdam.

Hammond-Tooke, W.D. 2002. The uniqueness of Nguni mediumistic divination in southern Africa. Africa 72:277-292.

Hanretta, S. 1998. Women, marginality and the Zulu state: Women's institutions and power in the early nineteenth century. Journal of African History 39:389-415.

Hendricks, M.K., M. le Roux, M. Fernandes, and J. Irlam. 2003. Evaluation of a nutrition supplementation programme in the Northern Cape Province of South Africa. Public Health Nutrition 6:431-437.

Henn, B.M., C. Gignoux, A.A. Lin, P.J. Oefner, P. Shen, R. Scozzari, F. Cruciani, S.A. Tishkoff, J.L. Nountain, and P.A. Underhill. 2008. Y-chromosomal evidence of a pastoralist migration through Tanzania to southern Africa. PNAS 105:1069310698.

Hosegood, V. 2001. Africa Centre Demographic Information System household socoeconomic data. Africa Centre for Health and Population Studies, 2002, Mtubatuba, South Africa.

Hosegood, V., E. Preston-Whyte, J. Busza, S. Moitse, and I.M. Timaeus. 2007. Revealing the full extent of households' experiences of HIV and AIDS in rural South Africa. Social Science \& Medicine 65:1249-1259.

Huffman, T.N. 2010. Intensive El Nino and the Iron Age of South-eastern Africa. Journal of Archaeological Science 37:2572-2586.

Hull, E. 2010. International migration, 'domestic struggles' and status aspiration among nurses in South Africa. Journal of Southern African Studies 36:851-867.

Hung, H.C., K.J. Joshipura, R. Jiang, F.B. Hu, D. Hunter, S.A. Smith-Warner, G.A. Colditz, B. Rosner, D. Spiegelman, and W.C. Willett. 2004. Fruit and vegetable intake and risk of major chronic disease. Journal of the National Cancer Institute 96:1577-1584.

Ivers, L.C., K.A. Cullen, K.A. Freedberg, S. Block, J. Coates, and P. Webb. 2009. HIV/AIDS, undernutrition, and food insecurity. Clinical Infectious Diseases 49:1096-1102.

Jones, K.D.J., J.A. Berkley, and J.O. Warner. 2010. Perinatal nutrition and immunity to infection. Pedatric Allergy and Immunology 21:564-576.

Kaarsholm, P. 2005. Moral panic and cultural mobilization: Responses to transition, crime and HIV/AIDS in KwaZulu-Natal. Development and Change 36:133-156.

Kaschula, S., and K. Arbuckle. 2007. Fighting AIDS with traditional foods and organic practices. LEISA Magazine 23:9-11.

Kennedy, G., N. Fanou-Fogny, C. Seghieri, M. Arimond, Y. Koreissi, R. Dossa, F.J. Kok, and I.D. Brouwer. 2010. Food groups associated with a composite measure of probability of adequate intake of 11 micronutrients in the diets of women in urban Mali. The Journal of Nutrition 140:2070s-2078s. 
Kimani-Murage, E.W., K. Kahn, J.M. Pettifor, S.M. Tollman, D.B. Dunger, X.F. GomezOlive, and S.A. Norris. 2010. The prevalence of stunting, overweight and obesity, and metabolic disease risk in rural South African children. Bmc Public Health 10:13.

King, B.H., and B. McCuskert. 2007. Environment and development in the former South African bantustans. Geographical Journal 173:6-12.

Kolbe, T.L., E.V. Lambert, and K.E. Charlton. 1999. Effectiveness of a low intensity, community-based exercise program for older adults. The Journal of Nutrition, Health \& Aging 10:21-29.

Kuhnlein, H., B. Erasmus, H. Creed-Kanashiro, L. Englberger, C. Okeke, N. Turner, L. Allen, and L. Bhattacharjee. 2006. Indigenous peoples' food systems for health: Finding interventions that work. Public Health Nutrition 9:1013-1019.

Labadarios, D., N.P. Steyn, C. Mgijima, and N. Daldla. 2005. Review of the South African nutrition policy 1994-2002 and targets for 2007: Acheivements and challenges. Nutrition 21:100-108.

Laurie, S.M., and M. Faber. 2008. Integrated community-based growth monitoring and vegetable gardens focusing on crops rich in beta-carotene: Project evaluation in a rural community in the Eastern Cape, South Africa. Journal of the Science of Food and Agriculture 88:2093-2101.

Lewu, F.B., and S. Mavengahama. 2010. Wild vegetables in northern KwaZulu Natal, South Africa: Current status of production and research needs. Scientific Research and Essays 5:3044-3048.

LINDO Systems, Inc. 2002. LINDO/PC Release 6.1. LINDO Systems, Inc., Chicago, IL.

Lohse, N., A.B. Hansen, G. Pedersen, G. Kronborg, J. Gerstoft, H.T. Sorensen, M. Vaeth, and N. Obel. 2007. Survival of persons with and without HIV infections in Denmark, 1995-2005. Annals of Internal Medicine 146:87-95.

Mager, A. 2004. 'White liquor hits black livers': meanings of excessive liquor consumption in South Africa in the second half of the twentieth century. Social Science \& Medicine 59:735-751.

Mamabolo, R.L., M. Alberts, N.P. Steyn, H.A. Delemarre-van de Waal, N.G. Nthangeni, and N.S. Levitt. 2004. Evaluation of the effectiveness of iron and folate supplementation during pregnancy in a rural area of Limpopo province. SAJCN South African Journal of Clinical Nutrition 17:15-21.

Marcoe, K., W.Y. Juan, S. Yamini, A. Carlson, and P. Britten. 2006. Development of food group composites and nutrient profiles for the MyPyramid food guidance system. Journal of Nutrition Education and Behavior 38:S93-S107.

Marcos, A., E. Nova, and A. Montero. 2003. Changes in the immune system are conditioned by nutrition. European Journal of Clinical Nutrition 57:S66-S69.

Masarirambi, M.T., V. Mauvuso, V.D. Songwe, T.P. Nkambule, and N. Mhazo. 2010. Indigenous post-harvest handling and processing of traditional vegetables in Swaziland: A review. African Journal of Agricultural Research 5:3333-3341.

Masset, G., P. Monsivais, M. Maillot, N. Darmon, and A. Drewnowski. 2009. Diet optimization methods can help translate dietary guidelines into a cancer prevention food plan. The Journal of Nutrition 139:1541-1548. 
Maunder, E.M.W., and J.L. Meaker. 2007. The current and potential contribution of home-grown vegetables to diets in South Africa. Water SA 33:401-406.

Mazel, A.D. 1989. People making history: The last ten thousand years of hunter-gatherer communities in the Thukela Basin. Natal Museum Journal of Humanities 1:1-168.

McCann, J. 2001. Maize and grace: history, corn, and Africa's new landscapes, 1500 1999. Society for Comparative Study of Society and History:246-272.

Medicine, I.o. 2000. Dietary reference intakes. Applications in dietary assessment National Academy Press, Washington, D.C.

Misra, S., R. Maikhuri, C. Kala, K. Rao, and K. Saxena. 2008. Wild leafy vegetables: A study of their subsistence dietetic support to the inhabitants of Nanda Devi

Bioshpere Reserve, India. Journal of Ethnobiology and Ethnomedicine 4:15-23.

Mitchikpe, C.E.S., R.A.M. Dossa, E.A.D. Ategbo, J.M.A. Van Raaij, and F.J. Kok. 2008. Seasonal variation in food pattern but not in energy and nutrient intakes of rural Beninese school-aged children. Public Health Nutrition 12:414-422.

Mnkeni, A.P., P. Masika, and M. Maphaha. 2007. Nutritional quality of vegetable and seed from different accessions of Amaranthus in South Africa. Water SA 33:377380 .

Modi, M., A. Modi, and S. Hendriks. 2006. Potential role for wild vegetables in household food security: A preliminary case study in KwaZulu-Natal, South Africa. African Journal of Food, Agriculture, Nutrition and Development 6:1-12.

Mseleku, T.D. 2007. Department of Health- Annual report 2007.

Mvo, Z., J. Dick, and K. Steyn. 1999. Perceptions of overweight African women about acceptable body size of women and children. Curatonis 22:27-31.

Ncama, B.P., P.A. McInerney, B.R. Bhengu, I.B. Corless, D.J. Wantland, P.K. Nicholas, C.A. McGibbon, and S.M. Davis. 2008. Social support and medication adherence in HIV disease in KwaZulu-Natal, South Africa. International Journal of Nursing Studies 45:1757-1763.

Ndinda, C. 2009. 'But now I dream about my house': women's empowerment and housing delivery in urban KwaZulu-Natal, South Africa. Development Southern Africa 26:317-333.

Ndinda, C., C. Chimbwete, N. McGrath, R. Pool, and M.D.P. Grp. 2007. Community attitudes towards individuals living with HIV in rural KwaZulu-Natal, South Africa. Aids Care-Psychological and Socio-Medical Aspects of Aids/Hiv 19:92101.

Nelms, M., K. Sucher, and S. Long. 2007. Nutrition Therapy and Pathophysiology Wadsworth, Belmont.

Neumann, F.H., L. Scott, C.B. Bousman, and L.v. As. 2010. A Holocene sequence of vegetation change at Lake Eteza, coastal KwaZulu-Natal, South Africa. Review of Palaeobotany and Palynology 162:39-53.

NIH. 2007. Dietary supplement fact sheet: Iron. Available by National Institute of Health http://ods.od.nih.gov/factsheets/iron/.

NIH. 2009. Dietary supplement fact sheet: Magnesium. Available by National Institute of Health http://ods.od.nih.gov/factsheets/magnesium/.

NIH. 2010a. Dietary supplement fact sheet: Vitamin B12. Available by National Institute of Health http://ods.od.nih.gov/factsheets/vitaminb12/\#h3. 
NIH. 2010b. Dietary supplement fact sheet: Vitamin D. Available by National Institute of Health http://ods.od.nih.gov/factsheets/VitaminD-HealthProfessional/.

Nkomo, N., M. Freeman, and D. Skinner. 2009. Experiences of children heading households in the wake of the human immunodeficiency virus/acquired immune deficiency syndrome (HIV/AIDS) epidemic in South Africa. Vulnerable Children and Youth Studies 4:255-263.

Nordeide, M.B., A. Hatloy, M. Folling, E. Lied, and A. Oshaug. 1996. Nutrient composition and nutritional importance of green leaves and wild food resources in an agricultural district, Koutiala, in southern Mali. International Journal of Food Science and Nutrition 47:455-468.

Norman, R., D. Bradshaw, M. Schneider, D. Pieterse, and P. Groenewald. 2010. Frequently asked questions: What are the top causes of death in South Africa? Available by South Africa Medical Research Council www.mrc.ac.za/bod/faqdeath.htm.

O'Brien, E.M., and C.R. Peters. 1998. Wild fruit trees and shrubs of southern Africa: Geographic distribution of species richness. Economic Botany 52:267-278.

Odhav, B., S. Beekrum, U. Akula, and H. Baijnath. 2007. Preliminary assessment of nutritional value of traditional leafy vegetables in KwaZulu-Natal, South Africa. Journal of Food Composition and Analysis 20:430-435.

Papathakis, P.C. 2011. Personal communication.

Papathakis, P.C., N.C. Rollins, C.J. Chantry, M.L. Bennish, and K.H. Brown. 2007. Micronutrient status during lactation in HIV-infected and HIV-uninfected South African women during the first 6 mo after delivery. American Journal of Clinical Nutrition 85:182-192.

Papathakis, P.C., M.D. Van Loan, N.C. Rollins, C.J. Chantry, M.L. Bennish, and K.H. Brown. 2006. Body composition changes during lactation in HIV-infected and HIV-uninfected South African Women. Journal of Acquired Immune Deficiency Syndrome 43:467-474.

Peltzer, K. 2009. Self-reported diabetes prevalence and risk factors in South Africa: Results from the world health survey. Journal of Psychology in Africa 19:365370.

Pfeiffer, S., and C. Crowder. 2004. An ill child among mid-holocene foragers of southern Africa. American Journal of Physical Anthropology 123:23-29.

Picciano, M.F. 2003. Pregnancy and lactation: Physiological adjustments, nutritional requirements and the role of dietary supplements. Journal of Nutrition 133:1997S2002S.

Popkin, B.M. 1999. Urbanization, lifestyle changes and the nutrition transition. World Development 27:1905-1916.

Popkin, B.M. 2004. The nutrition transition: An overview of world patterns of change. Nutrition Reviews 62:s140-s143.

Popkin, B.M. 2006. Global nutrition dynamics: The world is shifting rapidly toward a diet linked with noncommunicable diseases. American Journal of Clinical Nutrition 84:289-298.

Prins, F.E. 2009. Secret San of the Drakensberg and their rock art legacy. UNISA 23:190-208. 
Puoane, T., K. Steyn, D. Bradshaw, R. Laubscher, J. Fourie, and V. Lambert. 2002. Obesity in South Africa: The South African demographic and health survey. Obesity Research 10:1038-1048.

Raschke, V., and B. Cheema. 2007. Colonisation, the New World Order, and the eradication of traditional food habits in East Africa: Historical perspecitve on the nutrition transition. Public Health Nutrition 11:662-674.

Raum, O.F. 1967. The interpretation of the Nguni first fruit ceremony. Paideuma, Mitteilungen zur Kulturkunde 13:148-163.

Redding, S. 2006. Sorcery and Sovereignty: Taxation, Power, and Rebellion in South Africa, 1880-1963 Ohio University Press, Athens.

Rice, A.L., L. Sacco, A. Hyder, and R.E. Black. 2000. Malnutrition as an underlying cause of childhood deaths associated with infectious diseases in developing countries. Bulletin of the World Health Organization 78:1207-1221.

Rudwick, S. 2008. "Coconuts" and "oreos": English-speaking Zulu people in a South African township. World Englishes 27:101-116.

Saitowitz, R., and M. Hendricks. 2010. Policy summary- The National Integrated Nutrition Programme. Available by Department of Health web.uct.ac.za/depts/chu/mch13m.rtf (verified 2/24/11).

SAPS. 2010. The crime situation in South Africa. South African Police Service.

Saunderson, M.D. 1995. Sustainable agriculture and rural development in South Africa. Outlook on Agriculture 24:163-165.

Schapera, I. 1930. The Khoisan Peoples of South Africa: Bushmen and Hottentots Routledge \& Kegan Paul Ltd, London.

Schneider, M., R. Norman, N. Steyn, and D. Bradshaw. 2007. Estimating the burden of disease attributable to low fruit and vegetable intake in South Africa in 2000. South African Medical Journal 97:717-723.

Schonfeldt, H.C., and N. Gibson. 2009. Healthy eating guidelines in the South African context. Journal of Food Composition and Analysis 22S:S68-S73.

Sealy, J. 2008. Late Holocene Foragers, pp. 83-86 Encyclopedia of archaeology, Vol. 1A. Academic Press, Amsterdam.

Seidman, G. 1999. Is South Africa different? Sociological comparisons and theoretical contributions from the land of apartheid. Annual Review of Sociology 25:419440.

Semba, R.D., and A.M. Tang. 1999. Micronutrients and the pathogenesis of human immunodefficiency virus infection. British Journal of Nutrition 81:181-189.

Semba, R.D., P.G. Miotti, and J.D. Chipangwi. 1994. Maternal vitamin A deficiency and mother-to-child transmission of HIV-1. Lancet 343:1593-1597.

Shahidi, F. 1997. Beneficial health effects and drawbacks of antinutrients and phytochemicals in foods, p. 1-9, In F. Shahidi, ed. Antinutrients and Phytochemicals in Food. American Chemistry Society, Washington, DC.

Skelcher, B. 2003. Apartheid and the removal of black spots from Lake Bhangazi in Kwazulu-Natal, South Africa. Journal of Black Studies 33:761-783.

Slater, H. 1973. Land, labour and capital in Natal: The Natal Land and Colonisation Company 1860-1948. Journal of African History XVI:257-283. 
Smith-Warner, S.A., D. Spiegelman, S. Yaun, H. Adami, W.L. Beeson, P.A. van den Brandt, A.R. Folsom, G.E. Fraser, J.L. Freudenheim, R.A. Goldbohm, S. Graham, A.B. Miller, J.D. Potter, T.E. Rohan, F.E. Speizer, P. Toniolo, W.C. Willett, A. Wolk, A. Zeleniuch-Jacquotte, and D.J. Hunter. 2001. Intake of fruits and vegetables and risk of breast cancer. JAMA 285:769-776.

Smith, F.I., and P. Eyzaguirre. 2007. African leafy vegetables: Their role in the World Health Organization's global fruit and vegetable initiative African Journal of Food, Agriculture, Nutrition and Development, Vol. 7.

Soden, P.M., and L.R. Fletcher. 1992. Modifying diets to satisfy nutritional requirements using linear programming. British Journal of Nutrition 68:565-572.

Solomon, A. 2005. Rock art in southern Africa. Scientific American Special Edition 15.

SSA. 2006. Mortality and causes of death in South Africa, 2003 and 2004: Findings from death notification. Available by Statistics South Africa www.statssa.gov.za.

SSA. 2007. Community Survey 2007. Statistics South Africa, Pretoria.

SSA. 2009. General household survey. Available by Statistics South Africa www.statssa.gov.za.

SSA. 2010. Social profile of South Africa, 2002-2009 03-19-00. Statistics South Africa, Pretoria.

Steketee, R.W. 2003. Pregnancy, nutrition and parasitic diseases. Journal of Nutrition 113:1661S-1667S.

Steyn, N.P., J.H. Nel, and A. Casey. 2003. Secondary data analyses of dietary surveys undertaken in South Africa to determine usual food consumption of the population. Public Health Nutrition 6:631-644.

Steyn, N.P., P. Wolmarans, J.H. Nel, and L.T. Bourne. 2007. National fortification of staple foods can make a significant contribution to micronutrient intake of South African adults. Public Health Nutrition 11:307-313.

Steyn, N.P., D. Labadarios, E. Maunder, J. Nel, and C. Lombard. 2005. Secondary anthropometric data analysis of the national food consumption survey in South Africa: The dourble burden. Nutrition 21:4-13.

Suttajit, M. 2007. Advances in nutrition support for quality of life in HIV+/AIDS. Asia Pacific Journal of Clinical Nutrition 16:318-322.

Theron, M., A. Amissah, I.C. Kleynhans, E. Albertse, and U.E. MacIntyre. 2007. Inadequate dietary intake is not the cause of stunting amongst young children living in an informal settlement in Gauteng and rural Limpopo Province in South Africa: The NutriGro study. Public Health Nutrition 10:379-389.

Thomas, D.S.G., and C. Twyman. 2007. Adaptation to climate change and variability: farmer responses to intra-seasonal precipitation trends in South Africa. Climate Change 83:301-322.

Thompson, L. 2000. A History of South Africa. 3rd ed. Yale University Press, New Haven.

Thornton, A. 2009. Pastures of plenty?: Land rights and community-based agriculture in Peddie, a former homeland town in South Africa. Applied Geography 29:12-20.

Timaeus, I.A., and T. Boler. 2007. Father figures: The progress at school of orphans in South Africa. Aids 21:S83-S93. 
Tomkins, A. 2001. Nutrition and maternal morbidity and mortality. British Journal of Nutrition 85:S93-S99.

Truswell, A.S. 1977. Diet and nutrition of hunter-gatherers. Ciba Foundation symposium:213-219.

USDA. 2005. USDA national nutrient database for standard reference, release 18. U.S. Department of Agriculture, Agricultural Research Service.

van der Walt, A.M., D.T. Loots, M.I.M. Ibrahim, and C.C. Bezuidenhout. 2009a. Minerals, trace elements and antioxidant phytochemicals in wild African darkgreen leafy vegetables (morogo). South African Journal of Science 105:444-448.

van der Walt, A.M., M.I.M. Ibrahim, C.C. Bezuidenhout, and D.T. Loots. 2009 b. Linolenic acid and folate in wild-growing African dark leafy vegetables (morogo). Public Health Nutrition 12:525-530.

Vincent, L. 2006. Virginity testing in South Africa: Re-traditioning the postcolony. Culture Health \& Sexuality 8:17-30.

Vorster, H.H., A. Kruger, B.M. Margetts, C.S. Venter, H.S. Kruger, F.J. Veldman, and U.E. MacIntyre. 2004. The nutritional status of asymptomatic HIV-infected Africans: Directions for dietary intervention? Public Health Nutrition 7:10551064.

Vorster, I.H.J., W.J. van Rensburg, J.J.B. Van Zijl, and S.L. Venter. 2007a. Re-creating awareness of traditional leafy vegetables in communities. African Journal of Food, Agriculture, Nutrition and Development 7:1-10.

Vorster, I.H.J., W. Jansen van Rensburg, J.J.B. van Zijl, and S.L. Venter. 2007b. The importance of traditional leafy vegetables in South Africa. African Journal of Food, Agriculture, Nutrition and Development 7:1-13.

Walker, C. 2009. Elusive equality: Women, property rights and land reform in South Africa. South African Journal on Human Rights 25:467-490.

Wallace, P.A., E.K. Marfo, and W.A. Plahar. 1998. Nutritional quality and antinutritional composition of four non-conventional leafy vegetables. Food Chemistry 61:287291.

Wallerstein, I., and W.G. Martin. 1979. Peripheralization of southern Africa, II: Changes in household structure and labor-force formation. Review III:193-207.

Walsh, C.M., A. Dannhauser, and G. Joubert. 2002. The impact of a nutrition education programme on the anthropometric nutritional status of low-income children in South Africa. Public Health Nutrition 5:3-9.

Wehmeyer, A.S. 1986. Edible wild plants of southern Africa: Data on the nutrient contents of over 300 species. National Food Research Institute, CSIR, Pretoria.

Welsh, S.O., C. Davis, and A. Shaw. 1993. USDA's Food Guide: Background and development. United States Department of Agriculture, Hyattsville, Maryland.

Whelton, P.K., J. He, J.A. Cutler, F.L. Brancati, L.J. Appel, D. Follmann, and M.J. Klag. 1997. Effects of oral potassium on blood pressure. JAMA 277:1624-1632.

WHO/FAO. 2003. Diet, nutrition and the prevention of chronic diseases. World Health Organization/Food and Agricultrual Organization, Geneva.

Wills, J., F. Chinemanan, and M. Rudolph. 2009. Growing or connecting? An urban food garden in Johannesburg. Health Promotion International 25:33-41. 
Wisner, B. 1989. Commodity relations and nutrition under apartheid: A note on South Africa. Social Science \& Medicine 28:441-446.

Zingoni, C., S.A. Norris, P.L. Griffiths, and N. Cameron. 2009. Studying a population undergoing nutrition transition: A practical case study of dietary assessment in urban South African adolescents. Ecology of Food and Nutrition 48:178-198. 


\section{APPENDIX A: THE NUTRITION TRANSITION IN KWAZULU-NATAL, SOUTH AFRICA}

Several interacting forces, such as physical environment, social and economic environment, technology, and culture work together to shape human food use and nutritional status (Goodman et al., 2000). Changes in these forces over time lead to a phenomenon known as the nutrition transition. The nutrition transition is characterized by large shifts in diet and activity patterns, reflected by nutritional outcomes. Five general stages of transition have been identified by Popkin (2006). The first is typified by hunter-gather societies in which diet and nutritional status are generally very healthy. The second is typified by the introduction of modern agriculture and reliance on cultivated cereal crops followed by a period of famine and malnutrition. In the third stage, income increases and famine recedes while many nutritional deficiencies disappear. In the fourth phase, overnutrition and decreased activity lead to the emergence of degenerative disease. The final phase optimizes health by reversing the negative tendencies of the proceeding periods through behavioral change. While all populations are expected to experience these transitions, they do not necessarily do so within the same periods of history or at the same rate (Popkin, 1999). Many lower- and middleincome countries are currently transitioning very rapidly from a period of receding famine to one dominated by nutrition-related noncommunicable disease as subsistence economies shift to modern industrialized ones (Popkin, 2004). Consequently, the populations in many of these countries are currently burdened with high rates of both undernutrition and overnutrition. South Africa is no exception. As of 2004, 23.4\% of 
South African deaths were caused by infectious and parasitic diseases, with an additional $13.9 \%$ of deaths being caused by diseases of the circulatory system (SSA, 2006). It has been proposed that a return to traditional foods and food habits will improve health and help combat the growing noncommunicable disease epidemic (Raschke and Cheema, 2007). Because food behaviors are shaped by many different factors, these factors need to be taken into account when attempting to bring about change. For this reason, the nutrition transition and motivating factors affecting the people of KwaZulu-Natal, South Africa, were reviewed from the time of the San hunter-gatherers, to the Bantu farmers, and on to the establishment of the Zulu Kingdom and the period of European colonization, followed by apartheid, and modern South Africa.

South Africa is located at the southern tip of the African continent. The western portion of the country receives an average annual rainfall of no more than 5 inches, resulting in desert conditions, while the average rainfall in the east reaches 40 inches per year, resulting in subtropical vegetation. Most of the land capable of supporting agriculture lies towards the east, in regions where precipitation averages at least 20 inches per year. Rainfall in all areas, however, is unpredictable and droughts are frequent. Soil quality is generally considered poor, but the country does possess great mineral resources in iron, gold, copper, diamonds, platinum, chrome, and uranium (Thompson, 2000). Currently known as the "garden province" of South Africa (Prins, 2009), KwaZulu-Natal is located in the eastern portion of the country, bordered by Swaziland and Mozambique to the north, the Indian Ocean to the east, Lesotho to the south, with the Drakensberg mountain range forming the western border (Prins, 2009). The geology, topography, and climate are remarkably varied within the province, with the land rising 
from relatively flat coastal plains in the east, up a series of plateau, to culminate with the Drakensberg mountain range. The majority of rainfall is received in summer (December through March), with great variation in both precipitation and temperature in the mountainous regions, while the coastal regions experience a modifying effect on climate thanks to the offshore Mozambique current and receives rain year round. Indigenous forests occur throughout the high rainfall areas. Afromontane forests are found in the western portion of the province, particularly on south and south-eastern facing slopes, while Indian Ocean coastal belt forests cover the coastal plain areas. These regions support a high proportion of South Africa's plant and wildlife diversity (Eeley et al., 1999). Between these forest bands lies savannah grassland (Prins, 2009).

\section{San Hunter-Gatherers}

(Pre-history-Mid 1800's)

It is believed by many that the predecessors of modern humans originated within the regions of southern and eastern Africa. From these distant origins emerged the San people, labeled Bushmen by early European settlers (Thompson, 2000). The San once covered nearly all of South Africa, but are now found mainly in the Central and Northern Kalahari Desert. They were a small people with brownish-yellow skin, living in small nomadic groups, meeting all needs of survival through hunting and gathering practices (Schapera, 1930). The San were not a literate people, and so reconstruction of their history depends mainly on archaeological finds, linguistics, and extrapolations from similar contemporary societies (Thompson, 2000). While some authors warn against generalizing characteristics of modern San with groups in other times and regions 
(Francis, 2009), most archaeologists are confident that the lifestyles of contemporary groups share many similarities with their distant predecessors (Sealy, 2008).

\section{Physical Environment}

Environment played an enormous role in shaping the way of life for the early inhabitants of South Africa. It is probable that many of the San people in the KwaZuluNatal area frequented the high mountain regions only in summer while following large herds of animals such as zebra, wildebeest, hartebeest, and eland (Prins, 2009). There is evidence that San groups had greater mobility, covered more territory, and maintained lower population densities during drought periods. Populations increased, territories shrunk, and mobility decreased when water and resources were more abundant (Bousman, 2005). San groups were also able to adapt to decreased mobility and increased population density by depending more on plant foods and small game, such as various types of rat which reproduced more quickly and were more dependable than large game (Mazel, 1989).

\section{Social and Economic Environment}

The basic social unit within San tribes was the nuclear family, with several families often banding together to form groups of between 20 and 80 people (Thompson, 2000). Interaction with neighboring bands was not uncommon and intermarriage between bands was in general expected. All San tribes were nomadic, moving from one place to another in search of plant foods and wild game. They did, however, have a defined territory they did not stray from except for short visits to neighboring groups and for trading purposes. Individual families might separate themselves from the group to seek food on their own for a time, but would then meet back up with the main group 
when resources were more abundant (Schapera, 1930). Members within a band were on fairly intimate terms, seeing each other almost constantly and cooperating in many ways. The work of hunting and gathering was generally complete by early afternoon, leaving evenings open for social visits (Schapera, 1930). Bonds were further strengthened by the practice of sharing game, particularly in times of plenty, among all members of the band (Dewar et al., 2006). Each band may have a chief, whose office was hereditary, but his authority in general was only slight. More often, the affairs of a group were regulated by the skilled hunters and older, more experienced men (Schapera, 1930).

A family among the San consisted of a husband and wife or wives and their dependent children. The marriage relationship was of great importance. Polygamy was never considered unacceptable, as long as the first wife consented, but occurrence varied depending on availability of food to support the larger family. Marriage occurred shortly after puberty. Once a young man found a suitable girl, he would seek to win the consent of her parents, particularly the mother, through various gifts, including game and vegetable foods. Eventually, if the gifts were accepted, he would take the girl to his hut and they were considered married. This was generally accompanied by a feast. The new couple would then typically reside with the wife's family until the birth of the first child and then join the band of the husband (Schapera, 1930).

The responsibilities of a husband and wife were distinctly defined. It was the wife's duty to build the hut, gather vegetable foods, provide water and firewood, and to prepare the meals. The husband's duty was to provide game for the family and band, and to make the clothing and some of the tools (Schapera, 1930). When necessity dictated, however, such as when a large amount of a food item was available that required many 
people to procure, all members of the band would participate (Dewar et al., 2006).

Despite rigid roles, wives were not considered inferior to their husbands, but rather equal companions (Schapera, 1930).

Family size was typically kept small. Children were nursed by their mothers until the age of three or four, with inclusion of vegetable foods early on. It is reported that among certain groups, children born before older children were weaned might be "thrown away" and buried some ways from camp directly after birth (Schapera, 1930). Infanticide may also have been used in the case of twins, deformities, or any other circumstance where the mother seriously doubted the child could survive (Pfeiffer and Crowder, 2004). Despite these apparent brutal practices, Bushmen were described as being very fond of their children, who "receive love and care without stint" (Schapera, 1930). Mothers would continue to carry their children on all daily excursions until the child was capable of looking after itself. Girls and all young children would accompany their mothers into the fields, or veld, in search of food, while older boys would accompany their fathers on the hunt, thereby gaining the majority of their education (Schapera, 1930).

The San had very few possessions and yet they are described as having lived in a sort of affluence (Thompson, 2000). All things required for survival were taken from materials that surrounded them in abundance. Because available resources generally exceeded wants, they had a sense of living abundant lives. When resources ran low, the group would move on. From this lifestyle came a philosophy of limited wants. Because all possessions had to be transportable, the people were content to possess only the things that could be easily carried. Unfortunately, this also applied to the elderly when they 
could no longer walk and to children when they were too numerous to be carried, who were then left behind to die (Thompson, 2000).

\section{Technology}

The San were experts at making use of the objects surrounding them to suit all their needs. Homes were made in caves or under overhanging rock-shelters while in the mountains and crude brush huts were constructed while in the flat country. Clothing was constructed entirely from animal skins (Schapera, 1930). Musical instruments were made from wood, catgut, and ostrich quills (Thompson, 2000). The majority of technology, however, was focused on food procurement. Digging sticks were used by the women to help with such tasks as extracting tubers from the ground or termites from their nests. These sticks were 3 to 4 feet long and might be tipped with sharpened bone and occasionally weighted with a stone for use in harder ground (Backwell et al., 2008; Schapera, 1930). Men used small bows for hunting constructed from a thin length of wood, tapered nearly to points at the ends, with a string made from animal sinews or wooden fiber worked into a strong cord. Arrow shafts were constructed from hollow reeds and tips were made from bone or wood, smeared with poison extracted from snakes, insects, or plants (Schapera, 1930). Bone barbs and hooks were also made for fishing (Backwell et al., 2008). Fire was created by drilling a thin hard stick into a softer, notched one. Food was prepared and cooked in wooden or clay bowls. While no form of agriculture was practiced among the San, fields were occasionally burned at the end of the dry season to encourage growth of bulbs and tubers in the coming wet season. Climate conditions made food storage difficult, but ostrich eggs were occasionally filled with water and stashed for future need (Schapera, 1930). 


\section{Culture}

Rock paintings and engravings, for which the San are perhaps most famous, are currently believed to be a reflection of their religious beliefs and ritual practices (Solomon, 2005). San religion included veneration for the moon, stars, and the sun, to whom prayers, predominantly for food, might be directed. Other supernatural beings that played prominent roles in mythology took the form of animals, believed once to have been men and women of the San predecessors. Rain was represented by an animal, most often taking the shape of a bull, which spread rain wherever he went. When angry, the rain had power to transform people into animals and other objects as well as to destroy with storms and lightening. Rain, however, was also respected for its role of bringing water and making food grow (Schapera, 1930). The spirits of San dead were not venerated, but were often associated with supernatural beings and could be manipulated or even controlled by skilled magicians (Prins, 2009).

Three events in San life were commonly celebrated, namely birth, puberty, and marriage. Of these three, a girl's puberty ceremony was the largest celebration. These events were often accompanied by feasts and dancing. In addition to ceremonial dances, dancing in general was often indulged in merely for pleasure. Most dances appear to have been imitations of episodes in the lives of wild animals and would be accompanied by singing and music (Schapera, 1930).

\section{Diet and Health}

Hunter-gatherer diets were typified by large variety in food items and a dependence on season. The !Kung tribe in Botswana, for example, consumed 85 different species of plants and 54 species of animals, although only nine plants and 17 
animals were consumed in large amounts. In general, plant foods provided the majority of calories in the diet. Mild seasonal energy malnutrition was common, which in part explains the small stature of the San people, but diets appear otherwise to have been very adequate, with good protein, vitamin, and mineral content. Associated health outcomes also appear to have been excellent with no obesity, very few dental caries, no hypertension, low serum cholesterol, and no evidence of coronary heart disease (Truswell, 1977).

\section{Bantu Farmers}

(Approximately 500 AD-1818)

Approximately 1500 years ago, groups of Bantu speaking agropastoralist began migrating from eastern to southern Africa (Henn et al., 2008). These people brought with them cultivated crops such as millet, sorghum, pennisetum, pumpkins, and beans, as well as domesticated animals such as dogs, sheep, goats, and cattle. For a time, the San reacted to these newcomers and the societal changes they brought by enveloping themselves more tightly in their own culture as a type of 'defensive traditionalism,' but eventually the bands of hunter-gatherers living in the Drakensberg are believed to have attached themselves to friendly farmer villages in the low-lying river valleys. Over the next few hundred years, the San alternated between living amongst the Bantu farmers and returning to their hunter-gatherer lifestyle in the mountains as various groups of migrants moved in and out of the area (Prins, 2009). Contact between the two groups continued with common intermarriage to the point that, when the first Europeans arrived in the area, 
the Drakensberg San did not appear remarkably different from the farmers (Francis, 2009).

\section{Physical Environment}

The first farmers in South Africa were drawn to the northern and eastern portions of the country where climatic conditions were ideal for the cultivation of their crops (Hall and Chirikure, 2008). Surface deposits of high-grade iron and copper ores were available in many areas and frequently utilized for the manufacturing of tools and ornaments (Thompson, 2000). Villages were established in the warm, low altitude tree and grassland habitats next to rivers with deep alluvial soils (Hall and Chirikure, 2008). Forests were often cleared to make room for settlements and pastures, to provide fuel for cooking, home construction, heating, and iron smelting, leading to dramatic vegetation changes (Neumann et al., 2010). The advent of the Little Ice Age around 1000 years ago, characterized by a cool dry period, pushed many of these early farmers to move on to other, more favorable areas, but new groups, predominantly of the Nguni ethnic group, soon arrived to take their place (Prins, 2009). Droughts, often widespread and severe, occurred every eight years or so, and locusts frequently ravaged crops, resulting in famine (Thompson, 2000). When conditions were particularly bad, some farmers may have turned to a hunter-gatherer lifestyle (Prins, 2009). Even in good times, indigenous plants were gathered for food and hunting, thanks to abundant game, was both a popular sport and an essential part of the economy (Thompson, 2000).

\section{Social and Economic Environment}

The mixed farming economy practiced by the Nguni was more productive than that of the hunter-gatherers and allowed for denser population levels. Extended families 
and their dependents would live together in small settlements of 50 to 400 people (Thompson, 2000). Settlements were most likely organized according to the Central Cattle Pattern, which is described by a zone of female residential houses and grain bins surrounding a male dominated area of cattle pens, smith, and meeting place (Huffman, 2010). Relations between members of a community have been described as being characterized by strong bonds of love and friendship. Bonds between families were strengthened through marriages, which involved complex negotiations between the two families and a series of exchanges of property, or lobola, most often in the form of cattle being given by the bridegroom's family to the family of the bride. Society was, however, very hierarchical. To at least some extent, men controlled women, elders controlled youth, rich controlled poor, and chiefs controlled commoners (Thompson, 2000).

Nguni men and women had similar, distinct roles as San men and women did, but perhaps on a less equal basis. Married men controlled their homesteads and were considered the owner of both the cattle and agricultural produce. Their responsibilities included clearing land for agriculture and cattle-keeping, building huts, and many crafts, including the manufacturing of clothing. The senior married man of a homestead was assisted by his unmarried sons and his clients, or poorer members of the group who would be lent animals to care for in return for the right to consume their milk and own a percentage of their offspring. Boys performed the majority of routine work with the cattle, leaving the men free to spend hours in the village center, making clothes and involving themselves in village government. The duties of a woman included raising the children, planting, weeding, and harvesting the crops, maintaining the home, making clay pots, and serving food. Not uncommonly, the women of a village would work the fields 
together, taking each woman's field in turn. Special work parties were also organized occasionally with groups of up to 200 people, both men and women, coming together for a task such as weeding, ending in a party when the work was done (Thompson, 2000).

Living in relatively permanent homesteads, farmers were able to possess far more items than the San were able to. Land belonged to the community, but individuals could own such things as weapons, axes, hoes, mats, household utensils, clothing, and ornaments. Cattle, above all things, determined a man's wealth. Described as having a strong acquisitive instinct, farmers would seek to increase their prestige and wealth by trading with people from neighboring villages. In this manner, goods might be moved over long distances from areas of plenty to those with short supply. Another practice associated with wealth was polygamy. A particularly rich and powerful chief, for example, might have as many as one hundred wives (Thompson, 2000).

Political units consisted of independent chiefdoms led by a hereditary chief who, with the aid of councilors drawn from the heads of homesteads within his territory, regulated the affairs of the people. The chief's duties involved hearing complaints, settling disputes, and receiving and entertaining visitors. Compensation was received in the form of sheep and cattle given for settling disputes, livestock seized by his men from neighboring chiefdoms, and the right to summon people to work for him, making him wealthy enough to marry more wives and provide more generous hospitality than any of his subjects. The chief's power, however, was limited by both necessity and custom. As there were no standing armies, police force, or jails, the chief had to rely on the cooperation of his councilors and the respect of his people for his power to be of any real 
effect. People unwilling to support a particular chief would simply leave and would be welcomed into other chiefdoms (Thompson, 2000).

\section{Technology}

Bantu speaking migrants not only brought agriculture to southern Africa, they also brought the knowledge of how to work iron. Ore was dug from the surface or mined in open slopes and then smelted in special clay furnaces. Once separated from the slag, usable metal was shaped by reheating and hammering. Blacksmiths, as the most specialized artisans in society, were given high status. Iron was used to make spears, hatchets, two-edged knives, hoes, awls, and spatulas. Copper was also utilized, but its use was almost exclusively decorative (Thompson, 2000).

The farmers of this area practiced swidden agriculture, in which a field would be cultivated for several years and then be allowed to lie fallow for a time. This method minimized risks involved in farming but did not produce impressive yields. Iron-headed hoes with wooden shafts were used when available, while spades made from hard wood were used where metal was less abundant (Thompson, 2000). Storage pits were constructed for the long-term storage of grain to be used in bad times and for more short term storage of other crops (Huffman, 2010).

\section{Culture}

The culture of the Bantu farmers of South Africa was based on an ideology of respect for elders, for the chief, and for established religious beliefs and rituals (Thompson, 2000). Religious beliefs were based on ancestor veneration, with ancestors being comprised of a vast, undifferentiated and impersonal group of patriarchal forebearers (Hammond-Tooke, 2002). It was believed that these spirits of ancestors had 
power over material things and could be contacted by religious specialists, or diviners, to invoke their support (Thompson, 2000). It was also commonly believed that natural events were caused by human action (Huffman, 2010). All illness and misfortune, for example, were believed to be caused either by ancestors, witches, or personal pollution (Hammond-Tooke, 2002).

Rituals and ceremonies, such as the annual first fruits ceremony and rainmaking, were an important part of Bantu farmer life. The annual first fruits ceremony involved the ritual eating of first fruits by the head of a homestead, thereby lifting the taboo on eating the crops from his dependents (Raum, 1967). Severe drought was dealt with through the ritual of rainmaking. Professional rainmakers were appointed by chiefs and were essentially herbalists, not diviners. The ceremony, rather than calling upon the ancestors for aid, was magical and involved the killing of a black beast and the use of strong rain-medicines (Hammond-Tooke, 2002). Temporary grain bins constructed for the ceremony were also burnt down, followed by the burning of the grain bins of the farmer implicated in the drought (Huffman, 2010).

\section{Diet and Health}

The Nguni had a richer and more reliable diet than the San and were generally a healthy people (Thompson, 2000). Sorghum and millet were the staple grain crops. Maize was introduced, most likely by Portuguese traders sometime after 1700 A.D. Although maize was less drought tolerant than sorghum, it had the advantage of maturing earlier, being able to stay in the fields longer, and yielding more food per unit of land and labor than any other grain. Despite these advantages, at this time maize was used only as a supplementary crop rather than a staple (McCann, 2001). Sour cow's milk was also an 
essential part of the diet and was drunk year round except in times of drought, pestilence, or war. Vegetables, both cultivated and gathered, were regularly consumed. Domestic and hunted meats were abundant. The farmers were familiar with medicinal plants and used them to help treat disease (Thompson, 2000).

\section{The Zulu Kingdom}

(Approximately 1818-1879)

By the end of the eighteenth century the population living in the KwaZulu-Natal region had grown to a level that could no longer be maintained under the current system. Land was no longer available for expansion and competition for resources became fierce. Strong chiefdoms began subduing their neighbors, forming loosely structured kingdoms (Thompson, 2000). Beginning in 1808, chief Dingiswayo of the Mthethwa began a war of conquest, uniting different communities under one government in an attempt to end the fighting. Shaka, an illegitimate son of the Zulu chief and member of Diniswayo's army, seized control of the Zulu chiefdom after his father's death and later gained control of the Mthethwa armies as well. Through his military conquests, he was eventually able to merge some three hundred formerly independent chiefdoms into the Zulu Kingdom. His empire would last less than one hundred years, but the social changes he instigated had an enormous impact on the people (Deflem, 1999).

\section{Physical Environment}

The period between 1750 and the mid 1840's saw extreme climate change taking place throughout the world as a result of increased volcanic activity. In most of southern and eastern Africa this climate change was manifested by three decades of unusually 
severe drought at the beginning of the nineteenth century. Wetter conditions during the previous half century had allowed for expansion of herds and increased dependence on maize as a staple crop, which allowed for increased population growth, but left the Nguni very vulnerable to drought. Drought conditions reduced crop production, killed stock animals, and facilitated the spread of disease and undernutrition. In areas hardest hit, food stores were soon depleted and the people were forced to subsist off grass and hardy, drought resistant roots and tubers. Families, tribes, and sometimes entire chiefdoms migrated where they could in search of sustenance, bartering for cattle when possible, taking food through raiding and violence when desperate (Ballard, 1986b).

\section{Social and Economic Environment}

The early nineteenth century was characterized by fear and brutal warfare. There had been no standing armies before this time and women and children were rarely killed. Shaka's conquest left between 50,000 and one million people dead, including women and children who were sometimes massacred in celebration of victory. Large areas of land were left virtually empty (Ballard, 1986b; Thompson, 2000). Those individuals and chiefdoms not incorporated into the Zulu kingdom were forced to flee to the north and west where many attempted to survive as hunter gatherers, but conditions were so bad that many resorted to cannibalism (Ballard, 1986b). Organized community life had virtually ended in some areas (Thompson, 2000). The scattered survivors could not cultivate crops because of the danger posed by enemies and cannibals (Delius, 2010). Conditions were slightly better for those who were incorporated into the Zulu Kingdom, but life would never be as it was before. 
Shaka established central authority among his people by weakening the bands of kinship and the authority of elders. When he seized power of the Zulu tribe, Shaka reorganized the community to reflect the Mthethwa military organization based on age groups rather than kinship (Deflem, 1999). All Zulu males, upon reaching the age of puberty, were enrolled in age based regiments and stationed in various royal or military homesteads to serve the king both as warriors and as his personal labor force. Tasks included building, herding cattle, and tending crops. These men were not allowed to marry until permission was granted by the king. By depriving homestead heads of much of their labor force and by controlling marriage, the king was able to control population growth and homestead expansion (Ballard, 1986b).

This period also saw a great widening in social, cultural, and material conditions among women. Some roles of women began to be determined by their social and political associations rather than inherent femininity. The most powerful class of women were members of the royal family who acted as heads of military installations. Another class of women were those acquired by the king for his own use and for doling out to his most wealthy and powerful subjects. These women consisted of daughters from important households given to the king as tribute and other women "requested" from their fathers when scouts thought they might interest the king. Aside from the freedom to criticize men to an extent not allowed other women, these women had little power over their own lives. Upon marriage, however, they did outrank all other wives (Hanretta, 1998). With the majority of mature men absent and the king requiring larger amounts of cattle and grain from his people, greater responsibility for rural production and 
homestead management fell on the shoulders of the women who remained at home (Thompson, 2000).

By altering social organization, Shaka and subsequent kings were able to establish a government based on centralized authority. The king still required the assistance of a staff of chiefs, but he was careful to limit their powers and maintain a rivalry among them so they would check one another but never dispute his will. The people were ruled through violence and terror, which was in part balanced out by a system of honor and rewards in which captured booty and food was distributed to the people (Deflem, 1999).

\section{Technology}

Shaka devoted the majority of his time and energy on expanding and reorganizing the Zulu army. His success in establishing the Zulu Kingdom was largely a result of the development of a short thrusting spear, or assegai, which was a far more efficient and lethal weapon than the long spears used by the enemy (Ballard, 1986b). Armies were trained to encircle the enemy in a shield to shield formation from which rivals could be stabbed in the heart (Deflem, 1999).

\section{Culture}

In his drive to obtain complete dominance, Shaka attempted to control all aspects of life, including culture. The power of sorcerers was neutralized by violence to give Shaka a monopoly on magical practices (Deflem, 1999). Traditional Nguni festivals were used to foster loyalty (Thompson, 2000). The first fruits ceremony became a national event, indicating that the king was in control of the processes of vegetable growth. In addition to the ceremonies marking main agricultural activities, the first fruits 
ceremony grew to include military matters and displays as well as the discussion and alteration of laws (Raum, 1967).

Another religious change during this time period was the increasing dominance of women as diviners (Hanretta, 1998). Many believe this may have come about through women's growing dissatisfaction with the amount of state interference imposed on their personal lives or through the disparity between the status of the common women and that of politically favored women (Hanretta, 1998). Because it was believed that ancestors spoke through diviners, women were able to make greater demands on men without threatening male dominance. Diviners were also at liberty to travel at will to visit patients (Hammond-Tooke, 2002).

\section{Diet and Health}

As has already been mentioned, this was a period of great famine and malnutrition for most of the people living in the area. There is some indication that warriors preferred living off captured livestock rather than field crops (Raum, 1967). The people had also come to depend on maize as a staple crop, despite its poor performance during drought conditions. Maize lacks the B vitamins found in other grains, like sorghum, and has a low level of usable protein (McCann, 2001). Historically, whenever maize has become a dominant staple crop, the nutrient deficiency disease, pellagra, often follows (Brenton and Paine, 2007). 


\section{Colonization}

(Approximately 1824-1948)

Although European colonization of South Africa began with the establishment of the Dutch Cape Colony in 1652, the majority of communities in the eastern section of the country were not significantly affected by white colonization before 1830 (Thompson, 2000). In 1824, having gained permission from King Shaka, a British trading post was established at Port Natal, modern Durban. Soon refugees, having been driven from the area by Zulu warriors, began creeping back, seeking safety at the port. Shaka viewed the trading post as a valuable part of his dominion and the white traders as his relations and so allowed the refugees to gather unmolested. Refugees, including groups from within the Zulu kingdom, continued flocking to the British occupied lands (Atkins, 1993). Groups of Afrikaner emigrants from the Cape Colony, also known as Voortrekkers or Trek Boers, also arrived in Natal in the late 1830's seeking political freedom. In consideration of these new arrivals, growing numbers of African refugees, and pressure from commercial and evangelical organizations, Natal was officially brought into the British Empire in 1842 in the hopes of maintaining stability. The discovery of diamonds and gold in 1867 and 1886 prompted further British expansion. The Zulu Kingdom was defeated by 1879 and, by the end of the century, all indigenous people of South Africa had been incorporated into states under white rule (Thompson, 2000). Lingering independent groups of San became assimilated into Nguni populations following pressure from colonial settlers, who hunted them down as vermin (Francis, 2009). Chiefs and headmen were allowed to continue with many of their traditional duties, but were now answerable to white administrators (Redding, 2006). A major feature of Natal's social 
and economic history during this period was the growth and later demise of a large African peasantry, at first capable of both supporting themselves and producing excess goods for barter, later being forced into poverty to ensure a cheap labor force for white colonists (Ballard, 1986a).

\section{Physical Environment}

The rise and fall of the African peasantry, while generally considered a product of political forces, was also mirrored by a series of natural events. The second half of the nineteenth century was a period of increased precipitation and climatic predictability in southern Africa, allowing for productive harvests and large amounts of population growth. The years 1895 to 1920, however, saw prolonged droughts, stock diseases, and crop pestilence. Maize and cattle, the commodities hardest hit by these disasters, were the same commodities upon which African prosperity were based. The first disaster struck in 1895 and 1896 with a combination of severe drought and locust invasion. Maize and sorghum, which comprised $48 \%$ and $36 \%$ of cultivated acreage respectively at the time, were highly susceptible to the locusts and large portions of the crops were destroyed. Crop losses as high as $95 \%$ led to malnutrition, indebtedness, and increased migration in search of work (Ballard, 1986a).

Cattle played an important role in African social and economic life. Marriage continued to depend on the groom's payment of cattle to the bride's family. Cattle were also used for transport of goods, dairy and meat production, and for hides. It was devastating, then, when the rinderpest plague hit Natal in 1897. Eighty to ninety percent of African-owned cattle died. This was more than twice the loss suffered by whites thanks to the African practice of grazing their cattle together on large communal pastures 
and unequal assistance from the government to help control spread of the disease. The effects of this loss were wide spread. Supplies could not be reliably transported into and out of rural areas due to transportation shortages. Marriage was often postponed or hindered due to insufficient cattle to pay the bridal price. Nutrition, particularly among the young, deteriorated with the loss of milk and meat. Doors were opened for the importation of cheap food. Cultivation suffered neglect with no oxen for plowing (Ballard, 1986a).

Locust infestations recurred in 1898, 1903-1904, and 1906. Severe drought and water shortage were experienced six of the twelve years between 1895 and 1907. A new cattle disease, the tick-born East Coast Fever, struck in 1904-1905 and killed off an estimated $70 \%$ of African herds by 1915 . White land owners now perceived that African farming practices were less productive, and therefore less profitable than new scientific methods, and so often drove their African tenants off the land (Ballard, 1986a). A few Africans were able to continue practicing subsistence farming on reserves set aside for their use. These reserves, however, were neither large enough or of sufficient quality to support a mixed farming economy (Atkins, 1993). By the 1920's some of these lands contained such heavy concentrations of people and livestock that the original vegetation was disappearing, streams and waterholes were drying up, and soil erosion was spreading (Thompson, 2000).

\section{Social and Economic Environment}

Refugees entering Natal were eager to reestablish their homesteads and traditional ways of life, but white settlers had different plans for them. Success of European settler activities, predominantly agriculture and later mining, depended on the availability of a 
large labor force (Wallerstein and Martin, 1979). Africans, possessing an enormous sense of self-worth and confidence, were willing enough to work, but showed far greater adeptness at controlling their wages and labor situations than the white employers liked. Black Africans maintained strong social ties and were able to quickly and efficiently spread word of specific employers to avoid or seek out, what wages to demand, and so forth. The African laborers sought employment that mirrored traditional tasks and also organized themselves based on an age hierarchy, with unmarried 'boys' being prohibited from taking employment considered appropriate only for married men. Work unions were frequently formed; strikes, picket lines, and boycotts were efficiently used to guarantee favorable labor conditions. Black women, still predominantly responsible for agriculture, brought in a substantial income from the production of surplus crops such as maize and pumpkin, trade in milk, eggs, and chickens, and the selling of home crafts and gathered commodities, such as honey, wild berries, firewood, and game meat in the town markets (Atkins, 1993). Dissatisfied with this situation, white colonists demanded a 'native policy' that would force black Africans to work for white employers at low cost. Indentured laborers from India, most of whom chose to stay after their labor term ended, were imported to fill short term needs (Slater, 1973). To fulfill long term needs, a plan was devised to ensure that black Africans could no longer exist outside the white controlled labor market (Wallerstein and Martin, 1979). This was eventually accomplished through a combination of land restriction and heavy taxes. An unplanned result was the profound degradation of traditional family structure.

Beginning in 1850, married black men were required to pay a yearly hut tax of seven shillings per hut. The tax was not unlike the traditional payment of tribute to a 
chief and was associated by the people with access to farming and grazing land, and so was paid without complaint. The hut tax doubled in 1875 and again was paid without complaint. Various other forms of tax were charged, including a dog tax and, for a while, marriage tax. To help raise money to pay these taxes, sons often sought work in the cities, sending part of their earnings home. Increasing numbers of young men and some young women migrated into urban areas where the money they earned gave them economic and social independence. Many were reluctant to relinquish that independence to return to their father's homes. Matters grew worse when a poll tax, to be paid by all black men over the age of 18, was initiated in 1906. Africans protested this new tax to no effect. Fathers feared this tax would further undermine their influence by making it more likely that their sons would use their income to pay their own taxes rather than supporting the family. Rebellion broke out and was quickly crushed. Paternal power within the family and a system of respect for elders, once so central in Nguni culture, would soon be dead (Redding, 2006).

A 'Natives Land Act' was passed in 1913, which set aside 8\% of the land in the colony for native use and made provisions against black African land purchase, rent tenancy, and share-cropping outside of these reserves (Ballard, 1986a). Shortage of land in association with high taxes eventually forced most men to leave home in search of work. Families were split by the periodic absence of men and the full burden of maintaining the home and bringing up children fell on the shoulders of women (Thompson, 2000). Women unable to support their families became economic liabilities to their husbands, resulting in increased rates of abandonment, lower rates of marriage, and lower expectations of stable marriages. Black women, considered legal minors under 
colonial rule, were often denied permission to migrate to urban areas and were cut off from the most lucrative jobs. Those women who did go to the cities did so illegally and were often forced to resort to degrading occupations such as prostitution or beer brewing, or to work as domestic servants for low wages (Redding, 2006).

The introduction of Christianity and efforts of missionaries also brought about social change for black Africans. Most missionaries were unable to separate Christianity from Western culture and expected converts to discontinue polygamy and to adapt Western dress, housing, and work ethic (Eason, 2009). Missionaries established elementary schools and medical dispensaries (Thompson, 2000). Africans recognized the usefulness of literacy and were eager to learn. Black Christian converts were often the first to adapt new technology, such as the ox-drawn plow, took advantage of more consumer goods, were more likely to side with colonial government, and received positions of greater political power (Redding, 2006).

\section{Technology}

The main industries engaged in by European settlers in Natal were agricultural. Coffee, tobacco, and sugar plantations were established, but were not tremendously successful and most had disappeared by the beginning of the twentieth century. Black Africans, who now had access to the ox-drawn plow, out-produced and out-competed white farmers in the production of maize and vegetables, and so most land owners found it more profitable to rent out their land. The development of the mining industry, however, increased the attractiveness and profitability of commercial farming. Eventually black African farmers were replaced with new scientific methods of agriculture that were being practiced elsewhere in the Western world (Ballard, 1986a). 
Africans had little opportunity to take advantage of the new technology introduced by European colonists. Labor forces, particularly those associated with mining, were split between white and black workers. White laborers occupied all supervisory and high skill positions, received high wages, had opportunity for advancement, and lived in fairly good conditions, while black laborers were restricted to unskilled labor positions, received low wages, and were subject to harsh living conditions (Thompson, 2000).

\section{Culture}

Despite heavy economic pressures, many aspects of black African culture, with some structural adjustments, remained relatively intact during this period. Africans were described as being extremely social and would seek one another's company. It irked white managers to no end that African employees would not eat until all their workmates were assembled. The principle of hospitality was another sore point for white employers. Workers felt a mutual obligation to ensure the proper treatment of fellow human beings. Accordingly, the people demanded the right to extend basic civilities, such as food and lodging, to friends and relations visiting the area (Atkins, 1993). Traditional religious beliefs also persisted. European power was believed to have come from sorcery. Laws criminalizing witchcraft, witchcraft accusations, and the divining of witches encouraged a belief that the state was shielding witches for their own use. Many black Africans believed the natural catastrophes that led to crop failure and cattle death indicated ancestral disapproval after Christianity led many to neglect the ancestors and associated rituals. Belief in witchcraft and respect for ancestors persisted among Christian converts 
as well, although the extent of their belief was often obscured to remain in good standing with missionaries (Redding, 2006).

\section{Diet and Health}

African diet suffered greatly as European colonist gained more and more control. By law, employers were required to provide sufficient food of good quality to their workers, however most failed to do so (Atkins, 1993). Rations provided to miners were considered nutritious, but unattractive and monotonous (Thompson, 2000). Drought, pest, cattle plagues, and land shortages resulted in famine and common undernutrition (Ballard, 1986a). References to food in the literature almost exclusively name mealies, or maize. As diet quality decreased, so did health. Over one-fifth of children on reservations died within their first year. Conditions in the mines were extremely unhealthy, resulting in a high mortality rate associated with pneumonia, smallpox, tuberculosis, lung disease, and accidents (Thompson, 2000).

\section{Apartheid}

(1948-1994)

The British colonies of South Africa, after gaining control of lingering Afrikaner republics following the Anglo-Boer war of 1899-1902, united to become the Union of South Africa in 1910. Relations between British and Afrikaners remained tense, but they were united by the belief of white supremacy. Social and economic change in the 1930's placed strain on the established racial order. First, a growing number of black Africans found employment in the manufacturing industry and in urban services, leading to increasing and more permanent urban migration. Industrial employers began working 
around color-based barriers to fill their labor needs and some even entered into negotiations with black trade unions. Second, the government recognized the overcrowding, severe soil erosion and mass starvation occurring in the African land reserves following the 1913 Land Act and passed legislation to increase reserve area from $8 \%$ of the country to $13 \%$. Third, Afrikaner urban migration, following years of economic depression and drought in the early 1930's, resulted in a growing mass of poor whites. Afrikaner nationalism developed to address these social and economic changes (Bernstein, 1996). The Afrikaner-led Purified National party gained strength under these conditions and, feeding off racial fears, was able to gain control of the country following the elections of 1948. Their policy of apartheid, meaning "apartness," was founded on four main ideas. First, the population of South Africa was made up of four distinct racial and cultural groups-- White, Coloured, Indian, and African. Second, Whites, seen as the civilized race, were entitled to absolute control over the state. Third, White interests should prevail above all others, especially Black, and that the state was not obligated to provide equal facilities for subordinate races. Fourth, Whites formed a single nation while Africans belonged to several distinct nations, thus allowing Whites to form the largest group. A plethora of laws were enacted to bring this policy into force (Thompson, 2000).

\section{Physical Environment}

Control of where black Africans might live tightened during the reign of apartheid. Motivated by a need to control increasing opposition from this segment of the population, to protect the privileges of white workers, maintain a reserve of black labor, and to provide a dumping ground for excess population, Africans became required to live 
in the reserves, alternately known as homelands or bantustans, when not needed for work in white territory. These bantustans consisted of many noncontiguous pieces of the most arid and rocky land in the country (Wisner, 1989). KwaZulu was made up of 29 major and 41 minor fragments (Thompson, 2000). Many African communities living on white lands, known as "black spots," were forcibly removed to the bantustans, often under the pretext of natural resources conservation (Skelcher, 2003). Relocation separated people from familiar resources and resulted in loss of local knowledge and skepticism towards relying on the environment for security (Haag and Hajdu, 2005).

Conditions on the bantustans were bad. Typically, a family would be placed on a $1 / 4$ acre plot where they could keep no livestock and could barely produce enough food to survive (Skelcher, 2003). The environmental degradation that had already occurred due to overpopulation worsened (Thompson, 2000). As a result, only $17 \%$ of food needs could be produced on bantustan lands (FAO, 1982). Forced population concentration also overburdened the ability to adjust to climatic and other environmental changes (Wisner, 1989), which, as has already been seen, are common in South Africa. Conditions were equally bad for black Africans living in urban settings. Separate from each town was a black location where Africans employed in the towns lived on tiny plots in mud, clapboard, or corrugated iron buildings with earth latrines. Water had to be fetched from infrequent taps located along unpaved roads (Thompson, 2000).

\section{Social and Economic Environment}

Under apartheid, each individual at birth was assigned a racial category that would determine his or her legal and political rights for the remainder of his or her life. Interracial relationships were prohibited and public facilities and living areas were strictly 
divided along these racial lines (Seidman, 1999). The government, in response to an increased need for literate workers and to insure that "dangerous" ideas were not being taught in mission schools, assumed control of education for all racial groups. This greatly increased the number of black African children in school, but quality of education was vastly inferior to that of whites and curriculum was designed to instill in Africans the belief that there was no place for them in the community above certain levels of labor and that they were never to expect equal rights (Thompson, 2000). Because children often spent their days occupied with school, they no longer had the opportunity to work alongside their parents, learning about such things as wild plants (Vorster et al., 2007b). Perhaps the legislation with the most significant impact on African social structure was the formation of bantustans. The apartheid government justified the formation of bantustans based on the idea that these territories better represented African cultural systems-- tribally based, subsistence oriented, and unwilling or unable to adopt Western values; and that they were necessary to help African nations develop independently from the white state (King and McCuskert, 2007). Africans were granted citizenship within these homelands, thereby denying them citizenship in South Africa (Seidman, 1999). The homelands were administrated by Bantu authorities, mostly composed of tribal chiefs, under white guidance (Thompson, 2000). These tribal leaders were expected to maintain control over economic and political development in the homelands, allocating land (Thornton, 2009), providing work permits and drivers licenses, and overseeing education (Seidman, 1999). Because these bureaucrats largely depended on the apartheid government for their livelihoods, they offered few complaints 
on the state of affairs (Thompson, 2000). These leaders became increasingly less popular as their indebtedness to the apartheid government grew (Beall et al., 2005).

Degradation of traditional family structure and gender roles caused by the migrant labor system seen during colonization intensified. Bantustans were largely filled with the very young, elderly, sick or disabled, and unemployed women, while $60-80 \%$ of the economically active men were away working or seeking employment (Coovadia et al., 2009). Women were expected to remain in rural areas to perform subsistence agriculture unless employed as domestic servants in urban areas, but many continued migrating to urban centers, legally or otherwise, in search of better conditions (Seidman, 1999). Children were frequently left behind in the care of relatives, who were often old and unwell (Wisner, 1989). Demand for labor decreased as agriculture and industry became more capital intensive, resulting in high levels of unemployment for men (Bernstein, 1996). Unable to make a living off the land, depend on a spouse for income, or obtain profitable employment, the majority of women had to feed their children on income from very low paying informal activities and temporary work, which led to massive child malnutrition (Wisner, 1989). Nearly two thirds of the African population had incomes below the Minimum Living Level (MLL), defined as the lowest possible sum required for a household to live upon in South Africa. There was an incredible shortage of housing for Africans in the urban areas, so that in some places up to twenty people would be living in a typical four-room house (Thompson, 2000). Increasing poverty made the payment of bridal wealth, and therefore marriage, unobtainable for many and cohabitating without marriage became common. Premarital and teenage pregnancy became normal (Coovadia et al., 2009). Fathers who were unable to provide for their 
families were looked down upon by both the community and family. Frustrated by racial and economic oppression and by decreasing authority within the home, many men turned to violence (Campbell, 1992). Denied the traditional roles of adulthood, participation in criminal gangs among urban men, which allowed expression of masculinity through application of strength, courage, strategy, and camaraderie, as well as providing an income through criminal pursuits, became increasingly attractive. Abduction and rape became common features within townships (Coovadia et al., 2009). Many men and some women turned to alcohol to combat stress, alienation, and boredom. In some areas, Africans spent more of their income on liquor than on food. The physical violence, individual pain, desperation, shame, guilt, and loneliness associated with alcoholism, however, were ardently denied and kept deeply hidden (Mager, 2004).

\section{Technology}

Africans had access to few modern conveniences. Most living in the homelands had to travel long distances to fetch water from dirty streams (Skelcher, 2003) and by the late 1980 's, only $53 \%$ of rural households had a safe and accessible water supply and only $14 \%$ had access to adequate sanitation (Coovadia et al., 2009). Even those living near modern cities used earthen latrines and were serviced by infrequent water taps during much of the apartheid era (Thompson, 2000). Near the end of apartheid, 59\% of urban people had a tap within their home, but $33 \%$ still had access to only minimal sanitation facilities. By the same period, only 35\% of the South African population had access to electricity (Coovadia et al., 2009). Little opportunity existed for improvement as white capitalists were forbidden from investing directly in the homelands, leaving 
homeland governments dependant on inadequate subsidies from the apartheid government to function (Thompson, 2000).

White farmers benefited from massive state support for the mechanization of farms (Thompson, 2000) and the development of irrigation schemes (Wisner, 1989). Black farmers, on the other hand, were subject to "betterment" programs in which rural farmers were forced to move into villages, practice crop rotation and contour plowing, and restrict numbers of cattle. From a rural families' point of view, these programs were costly and provided little or no benefit and so were resisted (Redding, 2006).

\section{Culture}

The apartheid government encouraged the maintenance of indigenous culture out of fear that black Africans would eventually become well educated, thereby resulting in a loss of the manual labor force (Rudwick, 2008). Apartheid practices, however, also placed a great deal of strain on culture. The vast majority of black Africans were able to hold fast to their traditional values during this time. Extended family and kinship networks were heavily relied upon, particularly in providing the poor and incapacitated with food and shelter (Thompson, 2000). These relationships, however, experienced great stress and some erosion under mounting poverty (Wisner, 1989). Traditional religion also experienced a great deal of stress as forced removals of groups severed connections between people and their ancestral spirits when insufficient time was available to perform the proper rituals to move them to the new homelands. This left many wondering who they were, confused about their identity (Skelcher, 2003). At the same time, various African prophets developed Christian churches separate from European control that attempted to reinterpret Christianity and establish structures of 
religious authority not based on racial hierarchies. These churches helped the people reconstruct a sense of community and agency in a time of social trauma (Gunner, 2005).

\section{Diet and Health}

The conditions imposed by apartheid resulted in a large portion of the population living in chronic malnutrition, which was easily pushed over to frank starvation during periods of severe drought. Malnutrition was made worse by disrupted family structure. Children had a greater chance of being malnourished if they had unmarried parents and if they were looked after by someone other than their mother (Wisner, 1989). Unable to live off subsistence agriculture, people grew dependent on cheap imported foods such as white bread, white maize, and white sugar (Mager, 2004). Typical diets consisted of over $50 \%$ maize and included relatively small quantities of green and yellow vegetables, milk, meat, and fish. Diets tended to be worse among those who lived most of their lives in a rural setting (Abramson et al., 1960). An estimated 5\% of rural children suffered from marasmus, or severe energy deficiency, and 10-15\% from Kwashiorkor, or severe protein deficiency. Mortality by age five, considered an indicator of the overall nutritional situation, was around 50\% in the bantustans. Pellagra from niacin deficiency, rickets from vitamin D deficiency, scurvy from vitamin C deficiency, and vitamin A deficiency blindness were all common (Wisner, 1989).

Poor nutrition also had a devastating effect on other aspects of health. During a period when white South Africans experienced the diseases common to industrial nations and enjoyed some of the highest standards of health care in the world, their black counterparts suffered heavily from conditions common to developing countries, including pneumonia, tuberculosis, gastroenteritis, typhoid, typhus, measles, and rheumatic fever. 
There were also epidemics of cholera, polio, and bubonic plague. Mine workers often suffered from disabling injuries or contracted lung disease. Infant and childhood mortality rates were among the highest in Africa, predominantly due to inadequate nutrition. Official life expectancy rates, believed to be overestimates, were 51.2 years for men and 58.9 for women (Thompson, 2000).

\section{Modern South Africa}

(1994-Present)

Repression endured by black South Africans from the time of colonization through apartheid did not go uncontested. From time to time, the better educated and prosperous black Africans attempted to take advantage of the people's resentment to counter white dominance. Organizations, such as the African National Congress (ANC), the Inkatha movement (later the Inkatha Freedom Party), and the Congress of South African Trade Unions (COSATU), would eventually became powerful forces in bringing down apartheid (Thompson, 2000). These and similar organizations were kept in check by the white government until the 1970's when a protest culture became widespread among the black population that could not be controlled despite massive state violence and brutality. Economics also played a large role. The apartheid state was enormously expensive to run and, in a time of economic recession, trade sanctions, and the withdrawal of foreign investments, the structurally unsound South African economy struggled. A growing black African population, unable to support themselves in the homelands, flocked to urban areas in unprecedented numbers. Changes were made to apartheid in an attempt to salvage white supremacy, including the elimination of some segregation laws, increased funding for black education, and raised wages for black 
industrial workers, but these reforms were deemed insufficient and protests continued. By the late 1980's white industrial and political leaders were finally persuaded to enter into discussion with ANC leaders in the hopes of identifying a peaceful solution to the conflicts. Extremist groups, both white and black, did not want a peaceful reconciliation and violence continued to rack the nation, particularly in KwaZulu and Natal, where members of the IFC waged war on members of the ANC. Finally, after years of discussion and argument, a new constitution was agreed upon that promised civil, economic, and political rights for all. The African homelands became incorporated with the four original provinces into nine new provinces and in 1994 the first democratic election was held electing Nelson Mandela as president of a united nation (Thompson, 2000).

\section{Physical Environment}

During his presidency, Mandela instituted a Reconstruction and Development Program that attempted to improve living conditions for black Africans through measures that included redistribution of land, provision of low-cost housing, and extension of clean water and electricity supply (Thompson, 2000). Access to quality housing, though the houses were small (Ndinda, 2009), electricity, and clean water improved (Aguero et al., 2007), but efforts at land reform have been less successful. A large number of black Africans in KwaZulu-Natal continue to live in the rural areas of the former homelands on degraded and small landholdings with limited access to resources (Clover and Eriksen, 2009). Additional communal land is available, but those groups and individuals desiring to use it are ignorant of how to do so (Thornton, 2009). Land conservation efforts are being resisted because the people are suspicious that they will leave them worse off 
(Crane, 2006). Global climate change is predicted to bring about higher temperatures and alterations in rainfall patterns that may have a large impact on rural farmers (Thomas and Twyman, 2007). Within the cities, exhaust fumes from heavy traffic, factory emissions, and smoke from coal and kerosene fires cause dangerous levels of air pollution, while mining processes contaminate water supplies (Thompson, 2000).

\section{Social and Economic Environment}

The abolishment of apartheid and establishment of a democratic constitution was a tremendous step forward for South Africa, but the country still has to face the consequences of years of racial rule. Although legally equal, racial groups remain segregated (Thompson, 2000). Small improvements have been made in living conditions, but overall poverty and inequality have increased (Aguero et al., 2007). The government is dominated by one political party, creating an environment in which ideological conflicts continue to be expressed through violence (Kaarsholm, 2005). Crime rates continue to be high, and, in many aspects, have grown (SAPS, 2010). Economic conditions continued to deteriorate and unemployment rose as agricultural subsidies were removed and the economy opened up. Years of suppressed education have left many black Africans insufficiently skilled to compete in a global economy (Chazan and Whiteside, 2007). Mining industries, no longer able to increase profits by reducing wages for black workers, have found ways of restructuring to increase productivity and reduce the necessary labor force. Consequently, many households that had depended on remittances from mine workers are now without an income (Seidman, 1999). A grant system has been established that provides funds on a monthly basis to pensioners, poor children, and disabled individuals (Ndinda et al., 2007). These grants are received by 
$48.3 \%$ of households in KwaZulu-Natal and are the main source of income for $16.6 \%$ of households (SSA, 2009).

Post-apartheid reform policy has identified gender equality and promotion of woman's rights as key objectives, but little actual progress has been made (Walker, 2009). Traditional gender roles continue to be reinforced. For example, men continue to use violence, learned from watching how their fathers dealt with wives and children, to police family members. Women see this as undesirable, but unchangeable and something that must simply be avoided or tolerated (Campbell, 1992). Increasingly, however, women are using the legal system to counteract male aggression (Hull, 2010). By 2009, $44.1 \%$ of households in KwaZulu-Natal were headed by women and only $24.6 \%$ of children lived with both parents (SSA, 2010). Children born into homes where the father is not a resident tend to have lower birth weights, which is an indicator of reduced fetal survival, health, and development (Cunningham et al., 2010). Children who co-reside with their fathers also do better in school (Timaeus and Boler, 2007).

The HIV/AIDS epidemic is also wrecking havoc on South African families and society. The first isolated case of AIDS was reported in 1983 and prevalence in South Africa remained very low until 1990 (Chazan and Whiteside, 2007). In 1993, 4\% of women attending prenatal clinics were infected (Thompson, 2000). By 2007, up to 6.2 million South Africans were living with HIV/AIDS, with a prevalence of $40.2 \%$ among pregnant women (Ncama et al., 2008). AIDS is the leading cause of death in South Africa in the 15-44 year old age range, accounting for $73 \%$ of female and $61 \%$ of male deaths in 2000 (Hosegood et al., 2007). Highest rates of infection have consistently been seen in KwaZulu-Natal. HIV spread is fanned both by the culture of multiple partners 
that came about during apartheid due to the migrant labor system and a feeling of helplessness about the future that encourages risky behavior (Chazan and Whiteside, 2007).

Although community members recognize that they should treat infected individuals well and see to their emotional, material, and spiritual needs, translation into positive action is challenging. Infected individuals face social ostracism, loss of employment, break-up of marriages, and feelings of decreased worth and hopelessness (Ndinda, 2009). HIV-positive individuals are typically cared for within the family, with the brunt of the burden falling on the shoulders of older women as they care for their adult children. This brings about both emotional and economic challenges (Chazan and Whiteside, 2007). Children are also called upon to care for and take on the responsibilities of parents. Children whose parents die are often taken in by relatives or neighbors, but some are left to head their own households. An estimated $1.5 \%$ of children in South Africa are believed to be living in child-headed households, although actual numbers may be higher. These orphans tend to feel more anger, resentment, reduced self-esteem, hopelessness, and depression than non-orphans. Many of these households receive assistance from non-governmental organizations (NGOs), but this help is inadequate to meet all needs. For example, food parcels received from the NGOs usually run out before the next arrives. In general, loss of a parent to HIV/AIDS leaves children vulnerable to poor living standards and to physical and emotional abuse (Nkomo et al., 2009). 


\section{Technology}

Access to modern technology improved following the end of apartheid, but still falls far short of levels seen in developed nations. By 2009, 76.4\% of households in KwaZulu-Natal were connected to an electric supply (SSA, 2009). An estimated 66\% of South Africans have a working television, $64 \%$ have a working refrigerator, $73 \%$ have cell phones, and $16 \%$ have a computer (SSA, 2007). Use of paraffin or wood for cooking has decreased to $28 \%$ of households in KwaZulu-Natal. Eighty four percent of households have access to piped water and only $6.3 \%$ have no toilet facility or use a bucket toilet (SSA, 2009).

Transfer of technology to black farmers has been a difficult process. The vast majority of extension workers are white and do not know how to deal with black farmers and disadvantaged communities. Years of emphasis on monoculture production with high use of fertilizers and pesticides has led to a decrease in chemical pest control effectiveness, forcing commercial farmers to shift to integrated pest management (IPM). The adoption of this method can be difficult for small farmers. Small farmers are, however, now receiving assistance from both NGO's and the government to transfer the necessary technology for improving agriculture (Saunderson, 1995).

\section{Culture}

The challenges currently facing South Africa have brought about a cultural division among its citizens, with some seeking a revival of traditional values and practices while others wish to break from the past and create a new future. Traditionalists believe healing and wholeness can be found in reinstating the culture, morality, family structure, and personal integrity lost during colonialism and apartheid. For example, the 
disused tradition of virginity testing has recently been revived in hopes of combating rape, teenage pregnancies, and the spread of HIV/AIDS. Opponents are attempting to ban this practice because it suggests a return to the past. They argue that there is no pristine set of traditions to return to and that the present civil order is superior to the past. The practice of paying lobola has also come under attack with the argument that the high cost of marriage contributes to immorality and is a reason for couples not to marry. Many people take the middle road, recognizing that some cultural things are good, others bad, and that culture is changeable and needs to be transformed to respond to current needs (Kaarsholm, 2005; Vincent, 2006).

\section{Diet and Health}

South Africa is described as suffering from a quadruple burden of disease: infectious disease associated with poverty and under-nutrition, chronic disease associated with over-nutrition, the HIV/AIDS epidemic, and injury-related deaths (Faber and Wenhold, 2007). Diet appears to have shifted from a predominantly low-fat to a westernized high-fat diet, although this is not consistently seen in rural populations (Faber et al., 2001). Twenty three percent of the population of KwaZulu-Natal has inadequate access to food (SSA, 2009). The most commonly consumed foods are maize porridge, white sugar, tea, wheat and white bread (Steyn et al., 2003). Beans and rice are also common. Children eat slightly more fruit than adults, predominantly bananas and oranges. The most commonly consumed vegetables are cabbage and, to a lesser extent, imifino, a blend of locally gathered wild leafy greens (Faber et al., 2001). Despite availability of these and other wild foods, indigenous vegetables are often despised and avoided as poor people's food (Faber et al., 2010). Low variety in the diet predisposes 
individuals to low micronutrient intakes. Intakes of vitamin A tend to be particularly low, affecting eye health and immune function. A large portion of the population also suffers from iron deficiency anemia. Stunting caused by chronic malnutrition is seen in 19.3\% of children (Steyn et al., 2005). At the same time, 21\% of adolescents are overweight or obese (Kimani-Murage et al., 2010) and 31.8\% of adult black African women are obese (Charlton et al., 2004). Nutrition knowledge is poor among black South Africans. Only a quarter of black women feel that their current diet isn't sufficiently healthy, although the majority of people agree that they would eat healthier if they had more money. Overweight, even obese, body weight tends to have a positive connotation. Eating healthfully, in the end, takes priority only after taste, what the rest of the family will eat, and price (Charlton et al., 2004).

\section{Conclusion}

Environmental and social conditions have been the main driving forces behind the nutrition transition in KwaZulu-Natal, South Africa. The hunter-gatherer lifestyle of the San provided them with a diet rich in variety and adequate in nutrients, contributing to excellent health. Low population density and the ability to move about in search of food allowed them to maintain this healthy diet in spite of environmental instabilities. Close social ties helped ensure all members of the band were cared for. The arrival of agriculture with the Bantu farmers provided a more reliable food source, allowing greater population growth and a more stationary lifestyle. Diet and health remained excellent thanks to greater reliability of food and sustained variety, both from agriculture and continued use of collected foods and hunting. Strong family units and social ties 
persisted in ensuring all members of the community were cared for. As population levels grew, cereal crops, especially maize, became increasingly relied upon to meet the food needs of the people. Consequently, dietary variety decreased and nutrient adequacy suffered. These grain crops were also more susceptible to environmental stressors, such as drought and locust infestations, leading to frequent famine. During periods of drought and famine, the Nguni people subsisted largely by foraging, which may have led to a negative perception of wild foods as being famine foods.

The violence and bloodshed associated with the establishment of the Zulu kingdom exacerbated problems of starvation. Establishment of central authority shifted focus somewhat away from food production towards pursuits of honor and power. Family structure was weakened and social inequalities grew. Drought, locust infestations, and cattle plagues, along with taxes and land restrictions, effectively forced the black African people into poverty after the British seized control in the nineteenth century. Family structure continued to deteriorate as children gained opportunity and the need to see to their own needs, independent of the family. The migrant labor system also tore families apart and often placed the entire burden of agricultural production on women, who had access to only small plots of poor ground. These conditions intensified under apartheid. Unable to produce sufficient food to support themselves, people became dependent on cheap imported foods of low nutrient density. Many abandoned rural life and agricultural pursuits in hopes of finding better conditions in cities.

The end of apartheid has done little to change these poor conditions. Poverty remains wide spread, malnutrition and infectious disease are common, and traditional family structure is degraded. Many people desire to break with their traditional heritage 
and be seen as modern, which encourages adoption of a high-fat westernized diet associated with chronic disease. Access to modern conveniences, such as piped water, electricity, and improved sanitation, has increased and efforts are being made to assist black farmers to enhance productivity. Only when poverty is alleviated, access to and affordability of healthful foods is improved, and awareness of nutritional issues is increased, will there be hope that South Africa can transition away from the current pattern of receding famine and degenerative disease, into the more healthful pattern of behavioral change. 


\section{References}

Abramson, J.H., B. Gampel, N. Scotch, and C. Slome. 1960. Diet and serum protein levels of urban Zulu adults. British Journal of Preventive \& Social Medicine 14:190-195.

Aguero, J., M.R. Carter, and J. May. 2007. Poverty and inequality in the first decade of South Africa's democracy: what can be learnt from panel data from KwaZuluNatal? Journal of African Economies 16:782-812.

Atkins, K.E. 1993. The Moon Is Dead! Give Us Our Money! The Cultural Origins of an African Work Ethic, Natal, South Africa, 1843-1900 Heinemann, Portsmouth, $\mathrm{NH}$.

Backwell, L., F. d'Errico, and L. Wadley. 2008. Middle Stone Age bone tools from the Howiesons Poort layers, Sibudu Cave, South Africa. Journal of Archaeological Science 35:1566-1580.

Ballard, C. 1986a. The repercussions of rinderpest: cattle plague and peasant decline in colonial Natal. The International Journal of African Historical Studies 19:421450.

Ballard, C. 1986b. Drought and economic distress: South Africa in the 1800s. Journal of Interdisciplinary History XVII:359-378.

Beall, J., S. Mkhize, and S. Vawda. 2005. Emergent democracy and 'resurgent' tradition: Institutions, chieftaincy and transition in KwaZulu-Natal. Journal of Southern African Studies 31:755-771.

Bernstein, H. 1996. South Africa's agrarian question: Extreme and exceptional? Journal of Peasant Studies 23:1-52.

Bousman, C.B. 2005. Coping with risk: Later stone age technological strategies at Blydefontein Rock Shelter, South Africa. Journal of Anthropological Archaeology 24:193-226.

Brenton, B.P., and R.R. Paine. 2007. Reevaluating the health and nutritional status of maize-dependent populations: Evidence for the impact of pellagra on human skeletons from South Africa. Ecology of Food and Nutrition 46:345-360.

Campbell, C. 1992. Learning to kill? Masculinity, the family and violence in Natal. Journal of Southern African Studies 18:614-628.

Charlton, K.E., P. Brewitt, and L.T. Bourne. 2004. Sources and credibility of nutrition information among black urban South African women, with a focus on messages related to obesity. Public Health Nutrition 7:801-811.

Chazan, M., and A. Whiteside. 2007. The making of vulnerabilities: understanding the differentiated effects of HIV and AIDS among street traders in Warwick Junction, Durban, South Africa. Ajar-African Journal of Aids Research 6:165-173.

Clover, J., and S. Eriksen. 2009. The effects of land tenure change on sustainability: human security and environmental change in southern African savannas. Environmental Science \& Policy 12:53-70.

Coovadia, H., R. Jewkes, P. Barron, D. Sanders, and D. McIntyre. 2009. The health and health system of South Africa: historical roots of current public health challenges. www.thelancet.com 374:817-834. 
Crane, W. 2006. Biodiversity conservation and land rights in South Africa: Whither the farm dwellers? Geoforum 37:1035-1045.

Cunningham, S.A., I.T. Elo, K. Herbst, and V. Hosegood. 2010. Prenatal development in rural South Africa: Relationship between birth weight and access to fathers and grandparents. Population Studies-a Journal of Demography 64:229-246.

Deflem, M. 1999. Warfare, political leadership, and state formation: The case of the Zulu Kingdom, 1808-1879. Ethnology 38:371-391.

Delius, P. 2010. Recapturing captives and conversations with 'cannibals': In pursuit of a neglected stratum in South African history. Journal of Southern African Studies 36:7-23.

Dewar, G., D. Halkett, T. Hart, J. Orton, and J. Sealy. 2006. Implications of a mass kill site of springbok (Antidorcas marsupialis) in South Africa: hunting practices, gender relations, and sharing in the Later Stone Age. Journal of Archaeological Science 33:1266-1275.

Eason, A.M. 2009. 'All things to all people to save some': Salvation Army missionary work among the Zulus of victorian Natal. Journal of Southern African Studies 35:7-27.

Eeley, H.A.C., M.J. Lawes, and S.E. Piper. 1999. The influence of climate change on the distribution of indigenous forest in KwaZulu-Natal, South Africa. Journal of Biogeography 26:595-617.

Faber, M., and F. Wenhold. 2007. Nutrition in contemporary South Africa. Water SA 33:393-400.

Faber, M., V.B. Jogessar, and A.J.S. Benade. 2001. Nutritional status and dietary intakes of children aged 2-5 years and their caregivers in a rural South African community. International Journal of Food Sciences and Nutrition 52:401-411.

Faber, M., A. Oelofse, P.J. Van Jaarsveld, F.A.M. Wenhold, and W.S. Jansen van Rensburg. 2010. African leafy vegetables consumed by households in the Limpopo and KwaZulu-Natal provinces in South Africa. South African Journal of Clinical Nutrition 23:30-38.

FAO. 1982. Apartheid, Poverty and Malnutrition FAO Economic and Social Development Paper 24. FAO, Rome.

Francis, M. 2009. Silencing the past: historical and archaeological colonization of the Southern San in KwaZulu-Natal, South Africa. Anthropology Southern Africa 32:106-115.

Goodman, A.H., D.L. Dufour, and G.H. Pelto, (eds.) 2000. Nutritional Anthropology: Biocultural Perspectives on Food and Nutrition, pp. 1-376. Mayfield Publishing Company, Mountain View, CA.

Gunner, L. 2005. Remapping land and remaking culture: memory and landscape in 20thcentury South Africa. Journal of Historical Geography 31:281-295.

Haag, F., and F. Hajdu. 2005. Perspectives on local environmental security, exemplified by a rural South African village. Environmental Management 36:483-494.

Hall, S., and S. Chirikure. 2008. Herders, Farmers, and Metallurgists of South Africa, pp. 66-71 Encyclopedia of archaelogy, Vol. 1A. Academic Press, Amsterdam.

Hammond-Tooke, W.D. 2002. The uniqueness of Nguni mediumistic divination in southern Africa. Africa 72:277-292. 
Hanretta, S. 1998. Women, marginality and the Zulu state: Women's institutions and power in the early nineteenth century. Journal of African History 39:389-415.

Henn, B.M., C. Gignoux, A.A. Lin, P.J. Oefner, P. Shen, R. Scozzari, F. Cruciani, S.A. Tishkoff, J.L. Nountain, and P.A. Underhill. 2008. Y-chromosomal evidence of a pastoralist migration through Tanzania to southern Africa. PNAS 105:1069310698.

Hosegood, V., E. Preston-Whyte, J. Busza, S. Moitse, and I.M. Timaeus. 2007. Revealing the full extent of households' experiences of HIV and AIDS in rural South Africa. Social Science \& Medicine 65:1249-1259.

Huffman, T.N. 2010. Intensive El Nino and the Iron Age of South-eastern Africa. Journal of Archaeological Science 37:2572-2586.

Hull, E. 2010. International migration, 'domestic struggles' and status aspiration among nurses in South Africa. Journal of Southern African Studies 36:851-867.

Kaarsholm, P. 2005. Moral panic and cultural mobilization: Responses to transition, crime and HIV/AIDS in KwaZulu-Natal. Development and Change 36:133-156.

King, B.H., and B. McCuskert. 2007. Environment and development in the former South African bantustans. Geographical Journal 173:6-12.

Mager, A. 2004. 'White liquor hits black livers': meanings of excessive liquor consumption in South Africa in the second half of the twentieth century. Social Science \& Medicine 59:735-751.

Mazel, A.D. 1989. People making history: the last ten thousand years of hunter-gatherer communities in the Thukela Basin. Natal Museum Journal of Humanities 1:1-168.

McCann, J. 2001. Maize and grace: history, corn, and Africa's new landscapes, 1500 1999. Society for Comparative Study of Society and History:246-272.

Ncama, B.P., P.A. McInerney, B.R. Bhengu, I.B. Corless, D.J. Wantland, P.K. Nicholas, C.A. McGibbon, and S.M. Davis. 2008. Social support and medication adherence in HIV disease in KwaZulu-Natal, South Africa. International Journal of Nursing Studies 45:1757-1763.

Ndinda, C. 2009. 'But now I dream about my house': women's empowerment and housing delivery in urban KwaZulu-Natal, South Africa. Development Southern Africa 26:317-333.

Ndinda, C., C. Chimbwete, N. McGrath, R. Pool, and M.D.P. Grp. 2007. Community attitudes towards individuals living with HIV in rural KwaZulu-Natal, South Africa. Aids Care-Psychological and Socio-Medical Aspects of Aids/Hiv 19:92101.

Neumann, F.H., L. Scott, C.B. Bousman, and L.v. As. 2010. A Holocene sequence of vegetation change at Lake Eteza, coastal KwaZulu-Natal, South Africa. Review of Palaeobotany and Palynology 162:39-53.

Nkomo, N., M. Freeman, and D. Skinner. 2009. Experiences of children heading households in the wake of the human immunodeficiency virus/acquired immune deficiency syndrome (HIV/AIDS) epidemic in South Africa. Vulnerable Children and Youth Studies 4:255-263.

Pfeiffer, S., and C. Crowder. 2004. An ill child among mid-holocene foragers of southern Africa. American Journal of Physical Anthropology 123:23-29. 
Popkin, B.M. 1999. Urbanization, lifestyle changes and the nutrition transition. World Development 27:1905-1916.

Popkin, B.M. 2004. The nutrition transition: An overview of world patterns of change. Nutrition Reviews 62:s140-s143.

Popkin, B.M. 2006. Global nutrition dynamics: The world is shifting rapidly toward a diet linked with noncommunicable diseases. American Journal of Clinical Nutrition 84:289-298.

Prins, F.E. 2009. Secret San of the Drakensberg and their rock art legacy. UNISA 23:190-208.

Raschke, V., and B. Cheema. 2007. Colonisation, the New World Order, and the eradication of traditional food habits in East Africa: historical perspecitve on the nutrition transition. Public Health Nutrition 11:662-674.

Raum, O.F. 1967. The interpretation of the Nguni first fruit ceremony. Paideuma, Mitteilungen zur Kulturkunde 13:148-163.

Redding, S. 2006. Sorcery and Sovereignty: Taxation, Power, and Rebellion in South Africa, 1880-1963 Ohio University Press, Athens.

Rudwick, S. 2008. "Coconuts" and "oreos": English-speaking Zulu people in a South African township. World Englishes 27:101-116.

SAPS. 2010. The crime situation in South Africa. South African Police Service.

Saunderson, M.D. 1995. Sustainable agriculture and rural development in South Africa. Outlook on Agriculture 24:163-165.

Schapera, I. 1930. The Khoisan Peoples of South Africa: Bushmen and Hottentots Routledge \& Kegan Paul Ltd, London.

Sealy, J. 2008. Late Holocene Foragers, pp. 83-86 Encyclopedia of archaeology, Vol. 1A. Academic Press, Amsterdam.

Seidman, G. 1999. Is South Africa different? Sociological comparisons and theoretical contributions from the land of apartheid. Annual Review of Sociology 25:419440.

Skelcher, B. 2003. Apartheid and the removal of black spots from Lake Bhangazi in Kwazulu-Natal, South Africa. Journal of Black Studies 33:761-783.

Slater, H. 1973. Land, labour and capital in Natal: the Natal Land and Colonisation Company 1860-1948. Journal of African History XVI:257-283.

Solomon, A. 2005. Rock art in Southern Africa. Scientific American Special Edition 15.

SSA. 2006. Mortality and causes of death in South Africa, 2003 and 2004: Findings from death notification. Available by Statistics South Africa www.statssa.gov.za.

SSA. 2007. Community Survey 2007. Statistics South Africa, Pretoria.

SSA. 2009. General household survey. Available by Statistics South Africa www.statssa.gov.za.

SSA. 2010. Social profile of South Africa, 2002-2009 03-19-00. Statistics South Africa, Pretoria.

Steyn, N.P., J.H. Nel, and A. Casey. 2003. Secondary data analyses of dietary surveys undertaken in South Africa to determine usual food consumption of the population. Public Health Nutrition 6:631-644. 
Thomas, D.S.G., and C. Twyman. 2007. Adaptation to climate change and variability: farmer responses to intra-seasonal precipitation trends in South Africa. Climate Change 83:301-322.

Thompson, L. 2000. A History of South Africa. 3rd ed. Yale University Press, New Haven.

Thornton, A. 2009. Pastures of plenty?: Land rights and community-based agriculture in Peddie, a former homeland town in South Africa. Applied Geography 29:12-20.

Timaeus, I.A., and T. Boler. 2007. Father figures: the progress at school of orphans in South Africa. Aids 21:S83-S93.

Truswell, A.S. 1977. Diet and nutrition of hunter-gatherers. Ciba Foundation symposium:213-219.

Vincent, L. 2006. Virginity testing in South Africa: Re-traditioning the postcolony. Culture Health \& Sexuality 8:17-30.

Vorster, I.H.J., W. Jansen van Rensburg, J.J.B. van Zijl, and S.L. Venter. 2007. The importance of traditional leafy vegetables in South Africa. African Journal of Food, Agriculture, Nutrition and Development 7:1-13.

Walker, C. 2009. Elusive equality: Women, property rights and land reform in South Africa. South African Journal on Human Rights 25:467-490.

Wallerstein, I., and W.G. Martin. 1979. Peripheralization of southern Africa, II: changes in household structure and labor-force formation. Review III:193-207.

Wisner, B. 1989. Commodity relations and nutrition under apartheid: A note on South Africa. Social Science \& Medicine 28:441-446. 


\section{APPENDIX B: WILD FRUITS AND VEGETABLES OF KWAZULU-NATAL,}

\section{SOUTH AFRICA}

\begin{tabular}{|c|c|}
\hline $\begin{array}{l}\text { Acanthosicyos naudinianus } \\
\text { English: Herero cucumber, } \\
\text { wild melon, wild } \\
\text { watermelon }\end{array}$ & $\begin{array}{l}\text { Description: Herbaceous perennial with tuberous roots and long annual } \\
\text { stems. Leaves are usually deeply palmately 5-lobed. Flowers are } \\
\text { yellow to white. Fruit is elliptical and fleshy, covered with fleshy } \\
\text { spines. } \\
\text { Use: Mature fruits can be eaten raw or roasted. The skin and seeds can be } \\
\text { roasted and pounded to make a meal. }\end{array}$ \\
\hline $\begin{array}{l}\text { Allophylus decipiens }{ }^{2,3} \\
\text { English: false current } \\
\text { Zulu: umncandathambo, } \\
\text { umhlohlela }\end{array}$ & $\begin{array}{l}\text { Description: Tree or shrub with glossy trifoliate leaves. Bears bunches of } \\
\text { bright red berries. } \\
\text { Use: Edible fruit }\end{array}$ \\
\hline $\begin{array}{l}\text { Amaranthus sp. (A. dubius, } A \text {. } \\
\text { hybridus, A. spinosus, A. } \\
\text { thunbergii), } 4,16 \\
\text { English: amaranth, pigweed, } \\
\text { cockscomb } \\
\text { Zulu: imbuya }\end{array}$ & $\begin{array}{l}\text { Description: Herbaceous annual with erect stems 1-2 feet long. Dense } \\
\text { flower spikes, erect or drooping, producing small seeds. Grows in } \\
\text { costal and midland areas and in cultivated fields and waste places. } \\
\text { Often considered an obnoxious weed. } \\
\text { Use: Leaves and young seedlings can be eaten cooked or raw and have a } \\
\text { mild flavor. The seed can also be eaten cooked or raw and is most } \\
\text { often ground into flour or used in porridge. }\end{array}$ \\
\hline $\begin{array}{l}\text { Annona senegalensis } \\
\text { English: African custard- } \\
\text { apple }\end{array}$ & $\begin{array}{l}\text { Description: Shrub or small tree with flaking bark. Leaves are green to } \\
\text { blue-green and may have green to reddish hair on the undersides. } \\
\text { Creamy flowers produce bumpy fleshy fruits that turn from green to } \\
\text { yellow then orange with white pulp when ripe. } \\
\text { Use: Fruits are edible and are described as having a mild pineapple flavor. } \\
\text { Flowers can be used as a spice. Leaves can also be eaten. }\end{array}$ \\
\hline $\begin{array}{l}\text { Asystasia gangetica } \\
\text { English: creeping foxglove, } \\
\text { hunter's spinach } \\
\text { Zulu: Isihobo }\end{array}$ & $\begin{array}{l}\text { Description: Fast growing herbaceous groundcover. Leaves are simple } \\
\text { and dark green. Cream-colored flowers with purple markings are } \\
\text { produced in spring and summer. Thrives in part shade and can be } \\
\text { invasive. } \\
\text { Use: Edible leaves. }\end{array}$ \\
\hline $\begin{array}{l}\text { Berchemia } z e y h e r i^{6} \\
\text { English: red ivorywood } \\
\text { Zulu: umNcaka, umNini }\end{array}$ & $\begin{array}{l}\text { Description: Drought resistant evergreen or semi-deciduous tree. } \\
\text { Normally grows in dense groups with other trees. Leaves are a blue- } \\
\text { green color and have reddish leaf stalks. Yellowish or greenish-white } \\
\text { flowers are produced from Sep to Dec, followed by yellow to } \\
\text { brownish red fruit from Jan to Apr. } \\
\text { Use: Fruit is sweet and can be eaten fresh or dried. }\end{array}$ \\
\hline $\begin{array}{l}\text { Bidens pilosa } \\
\text { English: black jack } \\
\text { Zulu: amalenjane, uqadolo }\end{array}$ & $\begin{array}{l}\text { Description: Annual herbaceous plant commonly found in damp fields and } \\
\text { wastelands. Can be found along riverbanks throughout the year. } \\
\text { Use: Leaves can be eaten cooked or raw and have a resinous flavor. They } \\
\text { can also be dried for later use. }\end{array}$ \\
\hline
\end{tabular}




\begin{tabular}{|c|c|}
\hline $\begin{array}{l}\text { Boscia albitrunca } \\
\text { English: shepherd's tree, } \\
\text { caper bush } \\
\text { Zulu: inYokiziphinda, } \\
\text { umVithi }\end{array}$ & $\begin{array}{l}\text { Description: Small to medium tree often found in the drier parts of } \\
\text { southern Africa. Leathery gray-green leaves are arranged in clusters. } \\
\text { The trunk is smooth with white or whitish grey bark. Flowers, } \\
\text { produced from Jul to Nov, are yellow green and heavily scented. Fruit } \\
\text { is yellowish and smooth. } \\
\text { Use: The root can be pounded to make porridge and can also be used as a } \\
\text { coffee substitute. Fruits and flower buds are also edible. }\end{array}$ \\
\hline $\begin{array}{l}\text { Canthium inerme } \\
\text { English: turkey-berry, Cape } \\
\text { date } \\
\text { Zulu: umVuthwamini, } \\
\text { isiTobe }\end{array}$ & $\begin{array}{l}\text { Description: Growth form and size vary greatly. Branches occur in } \\
\text { opposite pairs with each pair being at right angles to the next. Leaves } \\
\text { are light green and glossy. Small flowers are produced in clusters } \\
\text { from Aug to Feb. The oval fruit, dark brown and wrinkly when ripe, is } \\
\text { produced from Oct to Apr and may remain on the tree for many } \\
\text { months. } \\
\text { Use: Edible fruit }\end{array}$ \\
\hline $\begin{array}{l}\text { Carissa bispinosa }^{6} \\
\text { English: num-num }\end{array}$ & $\begin{array}{l}\text { Description: Dense bush or rambling evergreen shrub with forked spines. } \\
\text { Leaves are glossy and dark green. Flowers are sweet smelling, small, } \\
\text { white or pink tinged, and clustered at twig tips. Small oval red berries } \\
\text { are produced with a slightly milky skin. Fruits and flowers can often } \\
\text { be found on the plant at the same time. } \\
\text { Use: The entire fruit, including seed, is edible and described as having a } \\
\text { delicious flavor. }\end{array}$ \\
\hline $\begin{array}{l}\text { Carissa macrocarpa }^{6} \\
\text { English: Natal plum, big } \\
\text { num-num } \\
\text { Zulu: Amatungulu }\end{array}$ & $\begin{array}{l}\text { Description: Fast growing dense ornamental shrub with Y-shaped spines. } \\
\text { Leaves are leathery, dark green, and shiny. Flowers, appearing from } \\
\text { spring to midsummer, are pure white and smell like orange blossoms. } \\
\text { Produces a large edible fruit. Grows mainly in coastal regions. } \\
\text { Use: Fruits can be eaten raw or be made into jams or jellies. }\end{array}$ \\
\hline $\begin{array}{l}\text { Cassine peragua } \\
\text { English: Cape saffron, false } \\
\text { saffron } \\
\text { Zulu: umKhukhuze, } \\
\text { umBofanyomogone }\end{array}$ & $\begin{array}{l}\text { Description: Evergreen shrub or small to medium tree. The trunk is often } \\
\text { crooked. Grayish brown bark falls off in thin scales to expose a } \\
\text { saffron-yellow layer. Leaves are dark green, thick and leathery, with } \\
\text { copper colored new growth. Leaf margins are irregularly serrated. } \\
\text { Small oval fruits are produced that turn from green to yellow to dark } \\
\text { purple when mature. } \\
\text { Use: Edible fruit. Leaves are toxic. }\end{array}$ \\
\hline $\begin{array}{l}\text { Centella asiatiea }^{4} \\
\text { English: marsh pennywort } \\
\text { Zulu: icudwane }\end{array}$ & $\begin{array}{l}\text { Description: A low growing evergreen perennial most often found shady } \\
\text { damp places. } \\
\text { Use: Leaves can be eaten cooked or raw and have an aromatic flavor. }\end{array}$ \\
\hline $\begin{array}{l}\text { Ceratotheca triloba } \\
\text { Englsih: wild foxglove } \\
\text { Zulu: udonqabathwa }\end{array}$ & $\begin{array}{l}\text { Description: An annual herb commonly found in summer rainfall areas, } \\
\text { especially in grasslands. The plant may be bushy or single stemmed. } \\
\text { Leaves are divided into } 3 \text { lobes with bluntly serrated margins. White } \\
\text { or mauve flowers are born on spikes in summer. Leaves, stems, and } \\
\text { flowers are covered in fine white hairs. } \\
\text { Use: Edible leaves. }\end{array}$ \\
\hline $\begin{array}{l}\text { Chenopodium album }{ }^{4} \\
\text { English: Fat hen } \\
\text { Zulu: imbikilicane }\end{array}$ & $\begin{array}{l}\text { Description: A common annual weed of cultivated ground that requires } \\
\text { moist soil and cannot grow in the shade. } \\
\text { Use: Leaves can be eaten cooked or raw, but preferably cooked, and have } \\
\text { a bland taste. Seeds can be dried and ground into a meal and eaten raw } \\
\text { or baked into bread. Seeds can also be eaten sprouted. The young } \\
\text { flowers can be cooked as a broccoli substitute. }\end{array}$ \\
\hline
\end{tabular}




\begin{tabular}{|c|c|}
\hline $\begin{array}{l}\text { Chenopodium murale } \\
\text { English: nettleleaf goosefoot }\end{array}$ & $\begin{array}{l}\text { Description: Annual weed growing predominantly on dunes and in waste } \\
\text { places on light soil. } \\
\text { Use: Leaves and young shoots can be eaten raw or cooked. The seed can } \\
\text { be eaten cooked and can be ground into a power and mixed with other } \\
\text { grains to make bread. }\end{array}$ \\
\hline $\begin{array}{l}\text { Chrysophyllum viridifolium } \\
\text { English: Fluted milkwood }\end{array}$ & $\begin{array}{l}\text { Description: Evergreen tree. Stems are often fluted at the base. Bark is a } \\
\text { splotchy pale gray and fairly smooth. Leaves are glossy and dark } \\
\text { green above and paler green below with fine rusty hairs, particularly } \\
\text { along the midrib. Flowers are white and are borne in clusters between } \\
\text { Jan and Feb. Fruit is slightly ribbed and yellow when ripe. } \\
\text { Use: Edible fruit }\end{array}$ \\
\hline $\begin{array}{l}\text { Citrullus lanatus } \\
\text { English: West African } \\
\text { watermelon, dessert } \\
\text { watermelon, bitter melon } \\
\text { Zulu: ibhece, ikhabe }\end{array}$ & $\begin{array}{l}\text { Description: Annual with long ridged vines commonly growing along } \\
\text { roadsides and on open ground in desert areas. Leaves are deeply } \\
\text { palmately 3-5-lobed. Fruits are white to green, grey or yellow, } \\
\text { uniform or striped. Flesh is white to pale green, yellow or red. } \\
\text { Use: The fruit is eaten raw and has a delicate sweet flavor and extremely } \\
\text { high water content. Unripe fruits can be added to soups. Leaves can } \\
\text { be eaten cooked. Seeds can be eaten raw or cooked, roasted or ground } \\
\text { into a powder to be used in breads and soups. }\end{array}$ \\
\hline $\begin{array}{l}\text { Cleome gynandra } \\
\text { English: African cabbage, } \\
\text { spider wisp } \\
\text { Zulu: umzonde, amazombe }\end{array}$ & $\begin{array}{l}\text { Description: Erect annual herb that can become woody with age. Stems } \\
\text { are sticky with glandular hairs. Leaves are palmately compound with } \\
\text { 3-5 leaflets. } \\
\text { Use: Fresh leaves are eaten cooked or dried for later use as a relish. }\end{array}$ \\
\hline $\begin{array}{l}\text { Cleome monophylla } \\
\text { English: spindle-pod } \\
\text { Zulu: isiwisa }\end{array}$ & $\begin{array}{l}\text { Description: A frost tender annual weed commonly growing in fields and } \\
\text { waste places. } \\
\text { Use: Leaves are eaten cooked. Young shoots and flowers can also be } \\
\text { used. The seed can be used as a mustard substitute. }\end{array}$ \\
\hline $\begin{array}{l}\text { Coccinia adoensis }{ }^{I} \\
\text { English: wild spinach }\end{array}$ & $\begin{array}{l}\text { Description: Perennial climber with woody roots and annual ribbed stems. } \\
\text { Leaves are unlobed to deeply 3-5-lobed. Fruit, available from Aug to } \\
\text { Jan, is elliptical and bright red when mature. Prefers semi-arid } \\
\text { conditions. } \\
\text { Use: Leaves can be eaten cooked. Fruit is edible. Roots are edible if well } \\
\text { cooked. }\end{array}$ \\
\hline $\begin{array}{l}\text { Coccinia quinqueloba } \\
\text { English: ivy gourd, scarlet } \\
\text { gourd }\end{array}$ & $\begin{array}{l}\text { Description: Deciduous vine growing from a large tuber. Leaves have } 5 \\
\text { deeply cut lobes. Male and female flowers are on separate plants. } \\
\text { Use: Edible fruit }\end{array}$ \\
\hline $\begin{array}{l}\text { Coccinia rehmannii } \\
\text { English: wild cucumber } \\
\text { Zulu: uselwa-lwenyoka }\end{array}$ & $\begin{array}{l}\text { Description: Perennial climber with slender annual or perennial stems and } \\
\text { large tuberous rootstock. Leaves are shallowly to deeply palmately 3- } \\
\text { 5-lobed. Fruit is smooth and bright red when mature. } \\
\text { Use: Root can be used year round as a source of water and starch. They } \\
\text { can be roasted in hot ashes and mashed or roasted in fat in a pot like } \\
\text { fried potatoes. }\end{array}$ \\
\hline Corallocarpus bainesii $^{I}$ & $\begin{array}{l}\text { Description: Perennial herbaceous prostrate plant. Older stems have } \\
\text { smooth ridged brown bark. Leaves are deeply palmately 5-lobed. } \\
\text { Flowers are born in dense clusters, followed by clusters of bright red } \\
\text { fruit. } \\
\text { Use: Leaves and stems can be eaten cooked as a salad and are palatable } \\
\text { but stringy. The fruits are sweet and edible when ripe. }\end{array}$ \\
\hline
\end{tabular}




\begin{tabular}{|c|c|}
\hline $\begin{array}{l}\text { Cucumis africanus }^{6} \\
\text { English: wild cucumber, } \\
\text { wild gherkin } \\
\text { Zulu: isende-lenja, uselwa- } \\
\text { lwemamba }\end{array}$ & $\begin{array}{l}\text { Description: Perennial herb. Stems die back each year and re-grow from a } \\
\text { thick woody root. Stems are long and usually prostrate, but will climb. } \\
\text { Leaves are deeply lobed, dull green, and roughly hairy. Flowers are } \\
\text { pale to dark yellow. Fruit is prickly, greenish yellow or white with } \\
\text { purplish brown or yellow stripes when mature. } \\
\text { Use: Fresh young leaves are eaten. Large, but not small, fruit are also } \\
\text { edible and are similar to cucumbers. }\end{array}$ \\
\hline $\begin{array}{l}\text { Cucumis metuliferus }^{6} \\
\text { English: jelly melon } \\
\text { Zulu: uhufafa }\end{array}$ & $\begin{array}{l}\text { Description: Annual climbing or trailing herb. All vegetative parts are } \\
\text { rough with hairs. Leaves are unlobed or palmately 3-5 lobed. Fruit is } \\
\text { somewhat triangular in shape with scattered stout spines and are } \\
\text { yellow to orange-red when ripe. The flesh is light or emerald-green } \\
\text { and jelly. Fruiting season is between Feb and Jul. } \\
\text { Use: Leaves are eaten cooked. Fruit may be bitter or non-bitter and } \\
\text { edible, with little flavor. Bitter forms are toxic. }\end{array}$ \\
\hline $\begin{array}{l}\text { Cyperus esculentus }^{4} \\
\text { English: tiger nut }\end{array}$ & $\begin{array}{l}\text { Description: Fast growing perennial that grows in muddy soil and shallow } \\
\text { water. } \\
\text { Use: The tuber can be eaten raw, cooked, or dried and ground into a } \\
\text { powder and are chewy with a nut-like flavor. The base of the plant can } \\
\text { also be used in salads. }\end{array}$ \\
\hline $\begin{array}{l}\text { Cyperus rotundus } \\
\text { English: nut grass }\end{array}$ & $\begin{array}{l}\text { Description: Perennial growing to } 2 \text { feet by } 3 \text { feet. Usually only found in } \\
\text { damp places. } \\
\text { Use: Tuber can be eaten cooked or raw and have a strong flavor when } \\
\text { freshly harvested that becomes milder if allowed to dry. The seed can } \\
\text { also be eaten but is very small. }\end{array}$ \\
\hline Cyphia sp., & $\begin{array}{l}\text { Description: Perennial herb with twining stems and tuberous root. } \\
\text { Use: Edible bulbs }\end{array}$ \\
\hline $\begin{array}{l}\text { Dactyloctenium aegyptium }{ }^{11,12} \\
\text { English: Egyptian crowfoot, } \\
\text { helicopter grass } \\
\text { Zulu: ungwengwe }\end{array}$ & $\begin{array}{l}\text { Description: A creeping annual grass that generally grows in heavy damp } \\
\text { soils. Seeds are born on finger-like structures. } \\
\text { Use: Edible seed. }\end{array}$ \\
\hline $\begin{array}{l}\text { Dialium schlechteri }{ }^{13} \\
\text { English: Zulu podberry } \\
\text { Zulu: umthiba }\end{array}$ & $\begin{array}{l}\text { Description: Tree with compound leaves and white sweetly scented } \\
\text { flowers. Fruit is round and velvety with red-brown hairs and orange } \\
\text { flesh. } \\
\text { Use: Edible fruit }\end{array}$ \\
\hline $\begin{array}{l}\text { Diospyros lycioides } \\
\text { English: bluebush, star- } \\
\text { apple, monkey plum } \\
\text { Zulu: Umbulwa }\end{array}$ & $\begin{array}{l}\text { Description: Deciduous to evergreen shrub to medium tree with blue- } \\
\text { green leaves. Mature bark is dark grey to brown and smooth, but } \\
\text { young branches are covered with long hairs. Flowers are tiny, creamy } \\
\text { yellow, bell-shaped, and sweetly fragrant. Male and female flowers } \\
\text { are produced on separate plants. Young fruit is hairy, but becomes } \\
\text { smooth when ripe and turns from fed to reddish brown to black with } \\
\text { jelly-like flesh. Fruits are produced from Jan to May. } \\
\text { Use: Fruit has a pleasant sweetish taste. }\end{array}$ \\
\hline $\begin{array}{l}\text { Diospyros natalensis }{ }^{14} \\
\text { English: granite jackal-berry }\end{array}$ & $\begin{array}{l}\text { Description: Evergreen shrub or small tree. Leaves are nearly circular and } \\
\text { dark glossy green, with lighter undersides. Leaves are densely hairy when } \\
\text { young. Small white flowers are born from Oct to Dec, followed by orange } \\
\text { to deep red acorn-shaped fruit. } \\
\text { Use: Edible fruit. }\end{array}$ \\
\hline
\end{tabular}




\begin{tabular}{|c|c|}
\hline $\begin{array}{l}\text { Diospyros scabrida } \\
\text { English: costal bladder nut }\end{array}$ & $\begin{array}{l}\text { Description: Evergreen shrub or tree with glossy green leaves and cream } \\
\text { colored flowers appearing in the summer and autumn, producing red } \\
\text { fruit. Most often found in sheltered spots among rocks and on forest } \\
\text { margins. } \\
\text { Use: Edible fruit. }\end{array}$ \\
\hline $\begin{array}{l}\text { Ehretia rigida }{ }^{6} \\
\text { English: puzzle bush } \\
\text { Zulu: umHlele }\end{array}$ & $\begin{array}{l}\text { Description: Deciduous small tree or shrub. Branches tend to be tangled } \\
\text { and arch downwards, giving the plant a haphazard look. Leaves can } \\
\text { be smooth or hairy. Pale mauve, blue, or white flowers bloom in } \\
\text { clusters in the spring, with male and female flowers on separate plants. } \\
\text { Fruits are orange to red and turn black when ripe. } \\
\text { Use: Ripe fruit is edible, but not tasty. Roots have medicinal uses. }\end{array}$ \\
\hline $\begin{array}{l}\text { Ekebergia capensis }^{6} \\
\text { English: Cape ash, Dogplum } \\
\text { Zulu: umNyamathi, uVungu, } \\
\text { uMathunzini-wezintaba, } \\
\text { umThoma }\end{array}$ & $\begin{array}{l}\text { Description: Large evergreen tree that can be found from sea level to high } \\
\text { altitudes. Large glossy green leaves are often tinged with a pinkish } \\
\text { patch or pink edges. Flowers are small and white and sweetly scented, } \\
\text { appearing from Sep to Nov. A fleshy bright red fruit ripens in autumn. } \\
\text { Use: Edible fruit. Other portions have various medicinal and ritualistic } \\
\text { uses. }\end{array}$ \\
\hline $\begin{array}{l}\text { Eleusine coracanna } \\
\text { English: Finger millet, } \\
\text { African millet, koracan }\end{array}$ & $\begin{array}{l}\text { Description: A tufted annual grass that produces white, red, brown, or } \\
\text { black grain. Sensitive to drought. } \\
\text { Use: Often used in making local beer and other beverages. Grain can be } \\
\text { made into flour and used to prepare porridge or cakes. }\end{array}$ \\
\hline $\begin{array}{l}\text { Emex australis }{ }^{4} \\
\text { English: devil's thorn, } \\
\text { doublegee } \\
\text { Zulu: inkunzane }\end{array}$ & $\begin{array}{l}\text { Description: Low-growing annual that flowers from Jan to Dec. Found in } \\
\text { many places, including grass plains, waste ground, and pastures. Has } \\
\text { nasty thorns. } \\
\text { Use: Young leaves can be eaten cooked. Acts as a laxative in large } \\
\text { quantities. }\end{array}$ \\
\hline $\begin{array}{l}\text { Euclea } \text { crispa }^{6} \\
\text { English: blue guarri } \\
\text { Zulu: iDungamuzi, umGwali }\end{array}$ & $\begin{array}{l}\text { Description: Small tree. Bark is often found covered in lichen. Leaves are } \\
\text { small, blue to grey, smooth and leathery, and vary in shape. Flowers } \\
\text { are produced from Oct to Feb and are whitish green to yellow and bell- } \\
\text { shaped, with male and female flowers being produced on separate } \\
\text { plants. Fruits ripen from reddish brown to black. } \\
\text { Use: Edible fruit. }\end{array}$ \\
\hline $\begin{array}{l}\text { Euclea natalensis }^{6} \\
\text { English: Natal guarri, Natal } \\
\text { ebony, large-leaved guarri } \\
\text { Zulu: iDungamuzi, } \\
\text { iChitamuzi, umZimane, } \\
\text { umTshikisane, inKunzane, } \\
\text { inKunzi-emnyama, } \\
\text { umHlalanyamazane, } \\
\text { umAnyathi }\end{array}$ & $\begin{array}{l}\text { Description: Shrub or small bushy tree with a dense spreading crown. } \\
\text { Dark green leaves are hard and leathery. Lower surface is often } \\
\text { covered with velvety red hairs and the veins are prominent. New } \\
\text { growth is gold tinged. Flowers are small, bell-shaped, and cream to } \\
\text { yellow in color. Male and female flowers are on separate plants. } \\
\text { Round fleshy berries are produced from Aug to Mar. They may be } \\
\text { smooth or bristly, yellow, orange, red, and black, and grow in dense } \\
\text { clusters. } \\
\text { Use: Edible fruit. Roots and bark have various medicinal uses. }\end{array}$ \\
\hline $\begin{array}{l}\text { Eugenia albanensis }^{16} \\
\text { English: } \\
\text { Zulu: u-Nanja }\end{array}$ & $\begin{array}{l}\text { Description: Low growing shrub with white flowers and ovate berry. } \\
\text { Use: Edible fruit }\end{array}$ \\
\hline Eugenia capensis $^{7}$ & $\begin{array}{l}\text { Description: Shrub or small tree which grows in evergreen forests. } \\
\text { Leathery leaves are oblong and elliptic. Flowers singly or in small } \\
\text { clusters from Oct to Apr, producing a red to purple round berry. } \\
\text { Use: Edible fruit }\end{array}$ \\
\hline
\end{tabular}




\begin{tabular}{|c|c|}
\hline $\begin{array}{l}\text { Ficus abulilifolia } \\
\text { English: large-leaved rock } \\
\text { fig, rock wild fig } \\
\text { Zulu: inkokhokho, impayi, } \\
\text { ubambematsheni }\end{array}$ & $\begin{array}{l}\text { Description: Small to medium deciduous or semi-deciduous tree usually } \\
\text { found on rocky hillsides and outcrops. Bark is whitish and smooth and } \\
\text { powdery. The trunk is usually twisted and contorted. Leaves are large } \\
\text { and heart-shaped. Fruit, yellow or red when ripe, is born in the leaf } \\
\text { axils of terminal branchlets. } \\
\text { Use: Edible fruit. }\end{array}$ \\
\hline $\begin{array}{l}\text { Ficus ingens } \\
\text { English: red-leaved fig } \\
\text { Zulu: umgonswane }\end{array}$ & $\begin{array}{l}\text { Description: Evergreen tree with a brief deciduous period. Prefers to grow } \\
\text { on rocky outcrops and cliff faces. All parts produce a milky latex } \\
\text { when broken. The bark is smooth and grey. Leaves are heart shaped, } \\
\text { dull green, and leathery with conspicuous yellow veins. New leaves } \\
\text { are reddish. Soft fleshy small figs are born in leaf axils or on the bare } \\
\text { stem below the leaves. They turn from white to pink, red, or purple } \\
\text { when mature and can be found on the tree throughout the year, but } \\
\text { peak in summer. } \\
\text { Use: Fruit is edible, but less palatable than some other fig varieties. The } \\
\text { milky latex is used as a disinfectant. }\end{array}$ \\
\hline $\begin{array}{l}\text { Ficus lutea }^{6} \\
\text { English: giant-leaved fig } \\
\text { Zulu: umvubu, omkhulu }\end{array}$ & $\begin{array}{l}\text { Description: Large tree with spreading crown and large glossy leaves with } \\
\text { yellow veining. Fruit is produced between Jun and Oct and can be } \\
\text { densely hairy or smooth. Thrives in warm, moist areas. } \\
\text { Use: edible fruit. }\end{array}$ \\
\hline $\begin{array}{l}\text { Ficus sur }^{6} \\
\text { English: broom cluster fig } \\
\text { Zulu: Umkhiwane }\end{array}$ & $\begin{array}{l}\text { Description: Large evergreen tree with large oval green leaves and a } \\
\text { massive spreading crown. Fruit is produced from Sep to Mar in large } \\
\text { clusters, often low down on the trunk or even at ground level arising } \\
\text { from the roots. Usually found on riverbanks, but can also be found in } \\
\text { drier woodlands. } \\
\text { Use: Fruit is commonly eaten fresh or as a jam. The tree is believed to } \\
\text { have magical powers. }\end{array}$ \\
\hline $\begin{array}{l}\text { Ficus sycomorus }^{17} \\
\text { English: sycamore fig, fig- } \\
\text { mulberry }\end{array}$ & $\begin{array}{l}\text { Description: A large tree with a dense round crown. Leaves are large and } \\
\text { heart-shaped, dark green above and lighter beneath with prominent } \\
\text { yellow veins. Fruit, yellow or red when ripe, is produced year round, } \\
\text { but peaks from Jul to Dec. The bark exfoliates in papery strips. } \\
\text { Use: Edible fruit }\end{array}$ \\
\hline $\begin{array}{l}\text { Flacourtia indica } \\
\text { English: Governor's plum }\end{array}$ & $\begin{array}{l}\text { Description: Fast growing large shrub or small tree with deep green } \\
\text { leathery leaves and large sharp spines. Large quantities of purplish-red } \\
\text { to blackish fruits with deep yellow-orange pulp are produced in late } \\
\text { summer. } \\
\text { Use: Ripe fruit can be eaten raw or made into jam or jelly. }\end{array}$ \\
\hline $\begin{array}{l}\text { Galinsoga pariflora } \\
\text { English: gallant soldier } \\
\text { Zulu: ushukeyana }\end{array}$ & $\begin{array}{l}\text { Description: Annual herbaceous plant growing to } 2 \text { feet. Requires moist } \\
\text { soil and can often be found in waste places and pavement in towns. } \\
\text { Flowers are produced from May to Oct. } \\
\text { Use: Leaves, stems, and flowering shoots can be eaten cooked or raw. } \\
\text { Dried portions can be ground into a powder and used as a flavoring in } \\
\text { soups. }\end{array}$ \\
\hline $\begin{array}{l}\text { Garcinia livingstonei }^{6} \\
\text { English: African mangosteen } \\
\text { Zulu: uGobandlovu }\end{array}$ & $\begin{array}{l}\text { Description: Small tree with thick woody young branches. Leaves are } \\
\text { blue-green with whitish veins and are waxy. Flowers are greenish, } \\
\text { whitish, or yellow and bloom from old wood. Fruits are orange with a } \\
\text { yellowish orange sticky juice. } \\
\text { Use: Delicious edible fruit. }\end{array}$ \\
\hline
\end{tabular}




\begin{tabular}{|c|c|}
\hline 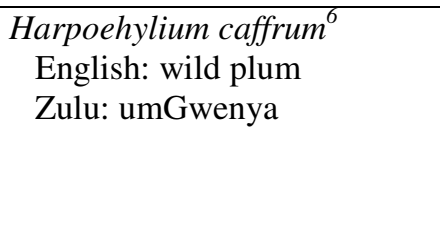 & $\begin{array}{l}\text { Description: Large evergreen tree, most often found in riverine forests, but } \\
\text { also common in as an ornamental garden tree. Often has supporting } \\
\text { buttress roots. Leaves are dark green, shiny, and sickle shaped. Plum- } \\
\text { like red fruits ripen in autumn. } \\
\text { Use: Edible fruit has a sour taist and is commonly used for making jams } \\
\text { and jellies. Bark has traditional medicinal uses and is used as a dye. }\end{array}$ \\
\hline $\begin{array}{l}\text { Hibiscus troinum }^{4} \\
\text { English: flower of an hour, } \\
\text { black eyed Susan, bladder } \\
\text { Hibiscus } \\
\text { Zulu: uvemvane olukhulu }\end{array}$ & $\begin{array}{l}\text { Description: Fast growing annual or short lived perennial, growing to } 2 \mathrm{ft} \text {. } \\
\text { Flowers from Jul to Aug. Cannot grow in the shade. A very } \\
\text { ornamental plant. } \\
\text { Use: Young leaves and shoots can be eaten raw or cooked. Root is also } \\
\text { edible, but very fibrous. The flowers are a diuretic. }\end{array}$ \\
\hline Inhambanella henriquesii $^{19}$ & $\begin{array}{l}\text { Description: Tall evergreen tree. Young leaves are a brilliant coppery-red } \\
\text { color. Bark is dark brown, rough, and flaking. Leaves cluster around } \\
\text { branch tips. Produces fruit } 2-4 \mathrm{~cm} \text { in diameter that is orange or } \\
\text { crimson when ripe. } \\
\text { Use: Fruit pulp is edible. }\end{array}$ \\
\hline $\begin{array}{l}\text { Ipomoea obscura } \\
\text { English: morning glory }\end{array}$ & $\begin{array}{l}\text { Description: Perennial herb. } \\
\text { Use: leaves can be eaten cooked as a relish }\end{array}$ \\
\hline $\begin{array}{l}\text { Justicia flava }^{6} \\
\text { English: yellow justicia } \\
\text { Zulu: impela }\end{array}$ & $\begin{array}{l}\text { Description: A perennial herb or shrublet with lanceolate leaves and } \\
\text { yellow flowers. Flowers from Sep to May and forms a good } \\
\text { groundcover. Can be found in many different areas, especially } \\
\text { disturbed land. } \\
\text { Use: Edible leaves. }\end{array}$ \\
\hline $\begin{array}{l}\text { Kedrostis Africana } \\
\text { English: baboon's cucumber }\end{array}$ & $\begin{array}{l}\text { Description: A member of the cucumber family with a carrot shaped } \\
\text { caudex, or underground thickened stem. Leaves are intricately shaped } \\
\text { and a small orange fruit is produced. } \\
\text { Use: Edible root. }\end{array}$ \\
\hline Kedrostis hirtella ${ }^{6}$ & $\begin{array}{l}\text { Description: Perennial herb with tuberous roots and annual stems. A } \\
\text { climber with bright green velvety leaves pentagonal in shape. Flowers } \\
\text { are greenish white or greenish yellow. Fruits are produced from Nov } \\
\text { to Apr and are rounded at the base and beaked at the tip. They are } \\
\text { hairless and green, with pale green or white speckles, becoming yellow } \\
\text { or bright orange-red and splitting open when ripe. Flesh is orange to } \\
\text { red. } \\
\text { Use: The raw red fruit is said by some to be edible, by others to be } \\
\text { poisonous. The tuberous root may also be edible. }\end{array}$ \\
\hline Kedrostis nana ${ }^{21}$ & $\begin{array}{l}\text { Description: Deciduous climber with tuberous root and pale green heart- } \\
\text { shaped medium leaves. Tiny greenish yellow flowers are followed by } \\
\text { oval red fruit. } \\
\text { Use: Edible root }\end{array}$ \\
\hline $\begin{array}{l}\text { Lablab purpureus }{ }^{4} \\
\text { English: hyacinth bean }\end{array}$ & $\begin{array}{l}\text { Description: Perennial climber. Seeds ripen from Sep to Oct. } \\
\text { Use: The mature seed is edible, but must be thoroughly cooked. It has a } \\
\text { mild flavor, is rich in protein, and can be used as a staple food. The } \\
\text { seed can also be sprouted and eaten raw. Young seed pods and } \\
\text { immature seeds can also be eaten raw or cooked. Leaves can be eaten, } \\
\text { but must be cooked. Flowers can be eaten raw or cooked. The edible } \\
\text { root is large and starchy. }\end{array}$ \\
\hline
\end{tabular}




\begin{tabular}{|c|c|}
\hline $\begin{array}{l}\text { Landolphia } \text { kirkii }^{22} \\
\text { English: wild apricot, wild } \\
\text { peach, rubber vine } \\
\text { Zulu: ibungu, umkuzi }\end{array}$ & $\begin{array}{l}\text { Description: Woody vines or sprawling shrubs with scented white flowers. } \\
\text { Milky latex is extruded when young bark or unripe fruit is damaged. } \\
\text { Fruits are round and approximately the size of a tangerine with tough } \\
\text { skin and a very sweet stringy pulp, produced from Nov to Mar. } \\
\text { Use: Edible fruit }\end{array}$ \\
\hline $\begin{array}{l}\text { Lantana camara }{ }^{23,24} \\
\text { English: Spanish flag, West } \\
\text { Indian lantana, red sage } \\
\text { Zulu: ubukhwebezane }\end{array}$ & $\begin{array}{l}\text { Description: An invasive vigorous shrub introduced to South Africa. } \\
\text { Flower heads, appearing throughout the year, start out yellow and } \\
\text { progressively turn salmon. } \\
\text { Use: Fully ripe fruit is edible. All other parts are toxic. }\end{array}$ \\
\hline $\begin{array}{l}\text { Lantana rugosa } 25 \\
\text { English: bird's brandy } \\
\text { Zulu: impema, } \\
\text { ubukhwebezane, } \\
\text { ubungungundwane, } \\
\text { uguguvama, } \\
\text { umkhukhuthwane, } \\
\text { utshwala benyoni }\end{array}$ & $\begin{array}{l}\text { Description: A non-invasive fast to moderate growing perennial } \\
\text { groundcover that tolerates both arid and coastal conditions. Small } \\
\text { flowers cluster at the end of stems, producing attractive clusters of } \\
\text { sweet berries. } \\
\text { Use: Edible fruit. }\end{array}$ \\
\hline $\begin{array}{l}\text { Manilkara concolor }{ }^{12} \\
\text { English: Zulu milkberry }\end{array}$ & $\begin{array}{l}\text { Description: Usually a shrub or much-branched small tree. Leaves tend to } \\
\text { cluster at the end of branches and are leathery dark green with a } \\
\text { yellowish midrib. Flowers are born in clusters near the end of } \\
\text { branches on long stalks between Aug and Oct. Fruit is a berry that } \\
\text { turns yellow to orange when ripe, pointed at the tip. Commonly grow } \\
\text { in sand forests and bushveld. } \\
\text { Use: Edible fruit }\end{array}$ \\
\hline $\begin{array}{l}\text { Manilkara discolor }^{14} \\
\text { English: forest milkberry }\end{array}$ & $\begin{array}{l}\text { Description: Shrub or small tree. Young branches are covered with } \\
\text { reddish brown hairs. Bark is gray and rough with vertical fissures. } \\
\text { Leathery leaves are dark green and smooth above, silvery and hairy } \\
\text { below. Round fruit is deep yellow to reddish-orange and ripens } \\
\text { between Dec and Mar. } \\
\text { Use: Edible fruit, considered one of the tastiest. }\end{array}$ \\
\hline $\begin{array}{l}\text { Manilkara mochisial } \\
\text { English: Zulu milkberry } \\
\text { Zulu: umNqambo }\end{array}$ & $\begin{array}{l}\text { Description: Small to medium semi-deciduous tree. Dark gray bark cracks } \\
\text { deeply in small blocks. Leaves are dull to glossy dark green above and } \\
\text { slightly paler beneath with a prominent yellow midrib. Flowers are } \\
\text { born in large clusters and produce almost round fruit with a short } \\
\text { pointed tip that ripens to yellow or orange between Nov and Jan. } \\
\text { Use: Fruit is edible and sweet. }\end{array}$ \\
\hline $\begin{array}{l}\text { Maytenus undata }^{26} \\
\text { English: Koko tree, South } \\
\text { African holly } \\
\text { Zulu: iDohame, iNqayi- } \\
\text { elibomvu, iGqwabali, } \\
\text { inDabulaluvalo, inqayi } \\
\text { elibomvu }\end{array}$ & $\begin{array}{l}\text { Description: Evergreen shrub or small tree. Bark flakes off in square } \\
\text { patches and young twigs are purplish. Leaves are pale green or } \\
\text { grayish and have toothed edges. Small greenish yellow or pinkish } \\
\text { white flowers are produced through spring and summer. Fruits are a } \\
\text { reddish brown three-lobed capsule that bursts open to expose bright } \\
\text { yellow seeds. } \\
\text { Use: Edible fruit }\end{array}$ \\
\hline $\begin{array}{l}\text { Mentha longifolia }^{6} \\
\text { English: wild mint } \\
\text { Zulu: ufuthana lomhlanga }\end{array}$ & $\begin{array}{l}\text { Description: Fast growing perennial herb. Strongly minty scent. Stem is } \\
\text { square-shaped and leaves are long and narrow with a sharp point. } \\
\text { Leaves are soft and usually coarsely hairy. Flower spikes vary in color } \\
\text { from white to mauve. Usually found growing in damp places. } \\
\text { Use: Leaves are popularly used in traditional medicine. They can also be } \\
\text { eaten in salads and vegetable dishes. }\end{array}$ \\
\hline
\end{tabular}




\begin{tabular}{|c|c|}
\hline $\begin{array}{l}\text { Mimusops sp. (M. caffra, M. } \\
\text { obovata, M.zeyheri) } \\
\text { English: red milkwood } \\
\text { Zulu: umNweba, } \\
\text { umHayihayi, amaSethole- } \\
\text { abomvu, umThunzi, } \\
\text { umNole, uMagayi, } \\
\text { umkhakhayi }\end{array}$ & $\begin{array}{l}\text { Description: Shrub to medium-sized tree. Leaves occur in tufts at the end } \\
\text { of branches. Produces yellow-orange to red oval fruit, } 3 / 4 \text { inch long } \\
\text { between Mar and Jun. Grows near the coast and in riparian } \\
\text { woodlands. } \\
\text { Note: } M \text {. caffra is a protected tree species and products may not be } \\
\text { collected without permission. } \\
\text { Use: Fruit pulp is sweet and starchy. Can be used in making jelly and an } \\
\text { alcoholic beverage. Bark has traditional medicinal uses. }\end{array}$ \\
\hline $\begin{array}{l}\text { Momordica balsamina } \\
\text { English: balsam pear } \\
\text { Zulu: intshungu, } \\
\text { intshungwana yehlathi }\end{array}$ & $\begin{array}{l}\text { Description: Perennial herb with tuberous roots and annual climbing } \\
\text { stems. The entire plant is bad smelling. Leaves are waxy and deeply } \\
\text { palmately 5-7 lobed. Fruit is spindle shaped, dark green, and has } 9 \text { or } \\
10 \text { rows of yellowish short blunt spines, ripening to bright orange or } \\
\text { red. The fruit opens automatically in three sections that curl back. } \\
\text { Flesh is sticky and scarlet red. Fruits and flowers are born throughout } \\
\text { the year, but mainly from Oct to May. } \\
\text { Use: Fruit flesh is edible and sweet, similar to watermelon. Leaves and } \\
\text { green fruit are also cooked and eaten. }\end{array}$ \\
\hline $\begin{array}{l}\text { Myrothamnus flabellifolius }{ }^{10} \\
\text { English: resurrection bush, } \\
\text { resurrection plant, bush tea }\end{array}$ & $\begin{array}{l}\text { Description: Prostrate or erect shrub that completely dries up in winter and } \\
\text { seems to be dead, then springs back to life within hours of the first } \\
\text { rainfall. Leaves are small and longitudinally pleated when dry. } \\
\text { Use: Edible leaves and twigs. }\end{array}$ \\
\hline $\begin{array}{l}\text { Opuntia ficus-indica } \\
\text { English: prickly pear } \\
\text { Zulu: umthelekisi }\end{array}$ & $\begin{array}{l}\text { Description: Evergreen succulent perennial growing to } 16 \times 16 \text { feet. Large } \\
\text { fleshy leaves are covered with numerous barbed hairs that are easily } \\
\text { dislodged when the plant is touched and can cause considerable } \\
\text { discomfort. Most often found in dry and rocky places. } \\
\text { Use: Fruit can be eaten raw, cooked, or dried and is sweet and gelatinous. } \\
\text { The leaves, or pads, can be eaten cooked like French beans. Flowers } \\
\text { can be eaten raw. The seed can be ground into a meal. }\end{array}$ \\
\hline $\begin{array}{l}\text { Oxygonum sinuatum }{ }^{I} \\
\text { English: stars talk } \\
\text { Zulu: untabane }\end{array}$ & $\begin{array}{l}\text { Description: Annual herb with green to red-brown stems that may be } \\
\text { smooth or hairy. White or pink flowers are born on a spike. A } \\
\text { common weed of fields and waste land. } \\
\text { Use: Leaves can be eaten raw or cooked and have an acidic taste. }\end{array}$ \\
\hline $\begin{array}{l}\text { Parinari capensis }^{6} \\
\text { English: sand apple }\end{array}$ & $\begin{array}{l}\text { Description: Creeping shrub that grows in dense groups in sandy regions } \\
\text { and rocky grasslands. Fruits are produced at ground level. } \\
\text { Use: Edible fruit }\end{array}$ \\
\hline $\begin{array}{l}\text { Physalis peruviana } \\
\text { English: Goldenberry, cape } \\
\text { gooseberry, cherry tomato } \\
\text { Zulu: quzumbele }\end{array}$ & $\begin{array}{l}\text { Description: Perennial, growing to } 4 \mathrm{ft} \text { tall. Grows in coastal regions and } \\
\text { disturbed areas. Flowers from Jul to Oct. The fruit is covered by a } \\
\text { papery calex. All parts of the plant are poisonous except the fruit. } \\
\text { Use: Fruit can be eaten raw or cooked and is described as being } \\
\text { deliciously bitter-sweet. Can be dried or stored up to } 3 \text { months fresh. } \\
\text { Rich in vitamins A, C, thiamine, niacin, and vitamin B12. }\end{array}$ \\
\hline $\begin{array}{l}\text { Physalis viscose } \\
\text { English: sticky gooseberry, } \\
\text { sticky ground cherry } \\
\text { Zulu: uqadolo }\end{array}$ & $\begin{array}{l}\text { Description: Small perennial growing to } 2 \text { feet. Can be found growing in } \\
\text { coastal sand dunes, sandy woods, pinelands, and grasslands. The fruit } \\
\text { is covered by a papery calyx. } \\
\text { Use: Ripe fruit, removed from the calyx, can be eaten raw or cooked and } \\
\text { has a pleasant cherry-like flavor. Leaves are also edible. }\end{array}$ \\
\hline
\end{tabular}




\begin{tabular}{|c|c|}
\hline $\begin{array}{l}\text { Podocarpus falcatus }^{6} \\
\text { Englsih: Outeniqua } \\
\text { yellowwood } \\
\text { Zulu: umSonti }\end{array}$ & $\begin{array}{l}\text { Description: Tall evergreen gymnosperm tree. Bark is smooth and ridged, } \\
\text { peeling off in flakes on older trees. Leaves have parallel veins and a } \\
\text { sharp point. Male and female cones occur on separate plants. Large } \\
\text { yellow fleshy fruit takes a year to ripen and hang on branches in } \\
\text { clusters. } \\
\text { Use: Ripe fruit is edible and very resinous. }\end{array}$ \\
\hline $\begin{array}{l}\text { Portulaca oleracea }^{4} \\
\text { English: purslane } \\
\text { Zulu: madilika }\end{array}$ & $\begin{array}{l}\text { Description: Fast growing annual reaching no more than } 1 \mathrm{ft} \text { in height. } \\
\text { Can be found in fields, waste ground, roadsides, cultivated fields, and } \\
\text { by the sea. Will produce leaves for most of the summer. } \\
\text { Use: Leaves and stems can be eaten cooked or raw. Considered a good } \\
\text { source of omega- } 3 \text { fatty acids. The leaves can be dried for later use. } \\
\text { Seeds can also be eaten raw or cooked, but are small and difficult to } \\
\text { use. Various medicinal properties. }\end{array}$ \\
\hline $\begin{array}{l}\text { Potrulacarea } \text { afra }^{6} \\
\text { English: Elephants food, } \\
\text { porkbush } \\
\text { Zulu: iNdibili, isiCococo }\end{array}$ & $\begin{array}{l}\text { Description: Large evergreen succulent shrub or small tree with thick } \\
\text { fleshy leaves } 1 / 2 \text { to } 1 \text { inch long and red stems. Clusters of rosy flowers } \\
\text { from late winter to spring. Grows in costal and midland regions in } \\
\text { warm situations, on rocky slopes, and in dry river valleys. } \\
\text { Use: Leaves can be eaten and are sour. Traditionally used to increase } \\
\text { breast milk by lactating mothers. Leaves are used to quench thirst. }\end{array}$ \\
\hline $\begin{array}{l}\text { Rapanea melanophloeos }^{6} \\
\text { English: Cape beech } \\
\text { Zulu: IsiCalabi, umaPhipha, } \\
\text { iKhubalwane, isiQalaba } \\
\text { sehlati }\end{array}$ & $\begin{array}{l}\text { Description: Evergreen tree with simple, oblong-lanceolate, dark green } \\
\text { leathery leaves that are pale green and maroon when young. Clusters } \\
\text { of small creamy yellow flowers bloom from Jun to Dec, producing } \\
\text { thin fleshed spherical fruit that is purple when mature. } \\
\text { Use: Fruit is edible. Bark and roots have been used medicinally for } \\
\text { respiratory problems, stomach, muscular, and heart complaints. }\end{array}$ \\
\hline $\begin{array}{l}\text { Raphanus raphanistrum }^{4} \\
\text { English: wild radish, } \\
\text { charlock, field wall flower }\end{array}$ & $\begin{array}{l}\text { Description: Annual weed commonly found in fields and pastures. Prefers } \\
\text { moist soil. } \\
\text { Use: Young leaves can be eaten cooked or raw and have a hot taste. Older } \\
\text { leaves become bitter. Seeds can be eaten cooked, raw, or sprouted and } \\
\text { have a pungent flavor. The flower buds can be used as a broccoli } \\
\text { substitute and should be lightly steamed. Young seedpods can be } \\
\text { eaten raw. }\end{array}$ \\
\hline $\begin{array}{l}\text { Rhiocissus digitata } \\
\text { English: Baboon grape }\end{array}$ & $\begin{array}{l}\text { Description: A woody climber, occasionally a bushy tree. Found in } \\
\text { grassland, bush, forest margins, and on coastal dunes. Leaflets are on } \\
\text { very short stalks, with the middle leaflet being longest. Margins are } \\
\text { entire. The undersides of leaves are covered with fine russet hairs. } \\
\text { New leaves are rust colored. Small roundish purple-black fruit ripen } \\
\text { in Mar to Jul. } \\
\text { Use: Fruits are acidic but edible. }\end{array}$ \\
\hline Rorippa nudiuscula ${ }^{7}$ & $\begin{array}{l}\text { Description: Perennial herb with irregularly toothed leaves in a rosette. } \\
\text { Yellow flowers form in a terminal raceme. } \\
\text { Use: Edible leaves. }\end{array}$ \\
\hline $\begin{array}{l}\text { Rumex lancealatus }^{27} \\
\text { English: common dock, } \\
\text { smooth dock } \\
\text { Zulu: iDolo lenkonyane }\end{array}$ & $\begin{array}{l}\text { Description: Perennial herb with fleshy to leathery leaves forming a } \\
\text { rosette at the root. Flowers are inconspicuous and are carried above } \\
\text { the leaves in clusters. } \\
\text { Use: Edible leaves. }\end{array}$ \\
\hline
\end{tabular}




\begin{tabular}{|c|c|}
\hline $\begin{array}{l}\text { Salacia kraussii }{ }^{19} \\
\text { Zulu: ibhonsi, umbhonsi, } \\
\text { ihelehele, umgunguluzane, } \\
\text { umnozane, uBangalala }\end{array}$ & $\begin{array}{l}\text { Description: Shrub with glossy leaves that vary greatly in shape and with } \\
\text { greenish flowers. } \\
\text { Use: Edible fruit. }\end{array}$ \\
\hline $\begin{array}{l}\text { Sclerocarya birrea } \\
\text { English: marula }\end{array}$ & $\begin{array}{l}\text { Description: Medium to large deciduous tree. Male and female flowers } \\
\text { are on separate trees. Leaves are compound. Fruits are produced from } \\
\text { Feb through Jun and are green on the tree, turning yellow after falling. } \\
\text { Use: Almost all parts of the tree have multiple uses. Fruits can be eaten } \\
\text { fresh or as a jelly. The white nut can be eaten as is or mixed with } \\
\text { vegetables. }\end{array}$ \\
\hline $\begin{array}{l}\text { Scutia myrtina } \\
\text { English: cat-thorn } \\
\text { Zulu: umsondeza, isiphingo, } \\
\text { isibinda, umthole }\end{array}$ & $\begin{array}{l}\text { Description: Evergreen spiny shrub. Leaves are pale green when young, } \\
\text { shiny and deep green when mature. Yellow green flowers appearing } \\
\text { in Mar through May are followed by fruits between Jul and Nov. } \\
\text { Use: Edible fruit. }\end{array}$ \\
\hline $\begin{array}{l}\text { Senna occidentalis }{ }^{29} \\
\text { English: coffee senna } \\
\text { Zulu: isinyembane }\end{array}$ & $\begin{array}{l}\text { Description: Annual or perennial herb with compound leaves. Flowers are } \\
\text { yellow and form sparse clusters. All parts of the plant are considered } \\
\text { toxic. } \\
\text { Use: Leaves are reportedly eaten during times of famine. }\end{array}$ \\
\hline $\begin{array}{l}\text { Setaria italic }^{4} \\
\text { English: Foxtail millet }\end{array}$ & $\begin{array}{l}\text { Description: Annual grass. Produces seeds in Sep and Oct. Requires } \\
\text { moist soil but can tolerate drought. } \\
\text { Use: Grain can be cooked like rice or be made into a flour. }\end{array}$ \\
\hline $\begin{array}{l}\text { Sideroxylon inerme } \\
\text { English: white milkwood } \\
\text { Zulu: aMasethole-amhlope, } \\
\text { uMakhwela-fingqane }\end{array}$ & $\begin{array}{l}\text { Description: Small to medium evergreen tree with dark bark, leathery dark } \\
\text { green leaves, and small greenish-white flowers with a strong } \\
\text { unpleasant smell. Young branches are always covered with fine hairs. } \\
\text { The small round fruit is produced from Feb to Sep and are purplish } \\
\text { black, fleshy, and contain milky latex. Grows in coastal forests } \\
\text { Use: Edible fruit. Bark and roots are used medicinally. }\end{array}$ \\
\hline $\begin{array}{l}\text { Solanum nigrum } \\
\text { English: black nightshade } \\
\text { Zulu: umsobosobo }\end{array}$ & $\begin{array}{l}\text { Description: A common annual garden weed that flowers from Jul to Sep. } \\
\text { Tolerates dry or moist soil. } \\
\text { Use: Fruits and leaves are cultivated for consumption, but there is } \\
\text { disagreement over whether or not they are poisonous. Ripe fruit can } \\
\text { be eaten cooked and has a pleasant musky taste. Young leaves and } \\
\text { new shoots can be eaten raw or cooked. }\end{array}$ \\
\hline $\begin{array}{l}\text { Sonchus asper } \\
\text { English: prickly sow thistle }\end{array}$ & $\begin{array}{l}\text { Description: Annual herbaceous plant that flowers from Jun to Aug. } \\
\text { Requires moist soils and can most commonly be found growing in } \\
\text { cultivated soil and waste places. } \\
\text { Use: Tender young leaves and stem tops can be eaten raw or cooked and } \\
\text { have a pleasant mild flavor. Stems should be bruised and washed to } \\
\text { remove the bitter milky juice before cooking or eating. The stems can } \\
\text { also be peeled and eaten raw like celery. }\end{array}$ \\
\hline $\begin{array}{l}\text { Sonchus oleraceus }{ }^{4} \\
\text { English: sow thistle, milk } \\
\text { thistle } \\
\text { Zulu: ihahabe }\end{array}$ & $\begin{array}{l}\text { Description: A biennial plant growing to } 3 \text { feet. A common weed on } \\
\text { waysides, waste places, and cultivated ground. Needs moist soil, but } \\
\text { cannot grow in the shade. } \\
\text { Use: Young leaves can be eaten raw or cooked and have a pleasant mild } \\
\text { flavor. Stems can be eaten cooked like asparagus and are best if the } \\
\text { outer skin is removed. The young root can be eaten cooked, but is not } \\
\text { well liked. The milky sap can also be used as chewing gum. }\end{array}$ \\
\hline
\end{tabular}




\begin{tabular}{|c|c|}
\hline $\begin{array}{l}\text { Sonchus wilmsii }{ }^{30} \\
\text { English: milk thistle }\end{array}$ & $\begin{array}{l}\text { Description: Annual herb. Leaves are soft and irregularly lobed, initially } \\
\text { forming a basal rosette. The stem contains a milky sap. Flower heads } \\
\text { are yellow. } \\
\text { Use: Young leaves can be eaten raw or cooked. }\end{array}$ \\
\hline $\begin{array}{l}\text { Stellaria media }{ }^{4} \\
\text { English: chickweed }\end{array}$ & $\begin{array}{l}\text { Description: Common low-growing garden weed that flowers and } \\
\text { produces seed year round. } \\
\text { Use: Young leaves can be eaten cooked or raw. Seeds can be ground into } \\
\text { a powder and used in making bread and thickening soup. }\end{array}$ \\
\hline $\begin{array}{l}\text { Strelitzia Nicolai }^{6} \\
\text { English: Natal wild banana } \\
\text { Zulu: Igceba }\end{array}$ & $\begin{array}{l}\text { Description: Tall foliage plant most commonly found growing in coastal } \\
\text { dune vegetation and in evergreen forests near the coast. Leaves are } \\
\text { enormous, shiny, and grey-green in color. These often tear in the wind } \\
\text { and resemble giant feathers. Flowers resemble the head of a bird and } \\
\text { appear throughout the year. Seeds are black with a tuft of bright } \\
\text { orange and are produced mostly in Mar to Jul. } \\
\text { Use: Immature seeds are edible and considered tasty. }\end{array}$ \\
\hline $\begin{array}{l}\text { Syzygium cordatum } \\
\text { English: Water berry }\end{array}$ & $\begin{array}{l}\text { Description: Small water-loving tree, often found near streams, on forest } \\
\text { margins, or in swampy areas. Leaves are elliptical to round and bluish } \\
\text { green on top, lighter underneath. Young leaves are reddish. White or } \\
\text { pinkish flowers are produced from Aug to Nov at the end of branches } \\
\text { and have numerous fluffy stamens. Fruits are oval berries and red to } \\
\text { dark-purple when ripe. } \\
\text { Use: The fruit has a slightly acidic flavor, but is edible. The berries can } \\
\text { also be used to make an alcoholic drink. }\end{array}$ \\
\hline $\begin{array}{l}\text { Tylosema fassoglense } \\
\text { English: sprawling bauhinia, } \\
\text { creeping bauhinia, marama } \\
\text { bean }\end{array}$ & $\begin{array}{l}\text { Description: Perennial herb or shrub with tuberous root and prostrate or } \\
\text { climbing stem. Young parts are covered with rusty hair. Fruit is } \\
\text { flattened and woody. } \\
\text { Use: Mature and immature seeds and pods can be eaten raw or cooked. }\end{array}$ \\
\hline $\begin{array}{l}\text { Urtica urens } \\
\text { English: annual nettle, } \\
\text { stinging nettle } \\
\text { Zulu: imbabazane, ububazi, } \\
\text { imbathi }\end{array}$ & $\begin{array}{l}\text { Description: Annual herb growing to } 2 \text { feet. The leaves have stinging } \\
\text { hairs that cause skin irritation. Common in cultivated land and waste } \\
\text { areas. Prefers moist soil. } \\
\text { Use: Young cooked leaves make an excellent spinach substitute. Can also } \\
\text { be dried for later use. }\end{array}$ \\
\hline $\begin{array}{l}\text { Wahlenbergia undulate } \\
\text { English: giant bell flower } \\
\text { Zulu: ushwaqa }\end{array}$ & $\begin{array}{l}\text { Description: Soft perennial or annual that grows throughout the summer. } \\
\text { Bluish-mauve to white star-shaped flowers bloom on long stems from } \\
\text { mid to late summer. Tiny white hairs are scattered along the stems and } \\
\text { leaves. } \\
\text { Use: Edible leaves, used mostly during famine. }\end{array}$ \\
\hline $\begin{array}{l}\text { Ximenia americana } \\
\text { English: yellow plum, sea } \\
\text { lemon }\end{array}$ & $\begin{array}{l}\text { Description: Small sprawling tree. Leaves are oval, bright green, and } \\
\text { smell like almonds. Flowers are pale and fruits are lemon-yellow or } \\
\text { orange-red. } \\
\text { Use: Fruit can be eaten and has a pleasant plum-like flavor. Cooked } \\
\text { leaves can also be eaten in small amounts. }\end{array}$ \\
\hline $\begin{array}{l}\text { Ximenia caffra } \\
\text { English: large sourplum } \\
\text { Zulu: umThundulukaobmyu }\end{array}$ & $\begin{array}{l}\text { Description: Small deciduous tree or shrub with glossy deep red fruit with } \\
\text { white spots and dark green leathery leaves. Small sweetly sented } \\
\text { flowers are produced from Aug to Oct, followed by the fruit. Found in } \\
\text { woodlands and grasslands. } \\
\text { Use: Fruit is tart, but edible and is best when slightly overripe. Oil from } \\
\text { the seed has various uses. The nut is also edible. }\end{array}$ \\
\hline
\end{tabular}




\begin{tabular}{|c|c|}
\hline $\begin{array}{c}\text { Ziziphus mauritiana }{ }^{32} \\
\text { English: Jujube, Chinee } \\
\text { Apple, buffalo thorn }\end{array}$ & $\begin{array}{c}\text { Description: A spiny evergreen shrub or small tree with drooping } \\
\text { branches. Produces a soft juicy red fruit with a white pulp and tough } \\
\text { wrinkly skin when ripe. Texture is similar to that of an apple. Thrives } \\
\text { in dry conditions. } \\
\text { Use: Fruit is eaten raw, pickled, dried, or in beverages. Various medicinal } \\
\text { uses. }\end{array}$ \\
\hline $\begin{array}{l}\text { Ziziphus mucronata } \\
\text { English: buffalo thorn } \\
\text { Zulu: um-Pafa, } \\
\text { umLahlankosi, isiLahla }\end{array}$ & $\begin{array}{l}\text { Description: Small flowering tree with reddish brown bark and shiny red } \\
\text { brown fruit. The main stem is green and hairy when young. Year old } \\
\text { branches often zigzag and are thorny. Flowers are inconspicuous and } \\
\text { occur from Oct to Feb. Fruit may stay on the tree long after leaves } \\
\text { have fallen, from Mar through Aug. Common in costal and midland } \\
\text { areas. } \\
\text { Use: Fruit is slightly sweet with a dry pulp and has been used to make } \\
\text { porridge, a coffee substitute, and beer. Root is used medicinally. The } \\
\text { tree has various other ritualistic uses. }\end{array}$ \\
\hline
\end{tabular}

Prota. Protabase basic search screen. Retrieved May 31, 2011, from http://database.prota.org/search.htm

${ }^{2}$ New Plant Nursery. Retrieved May 31, 2011, from http://plants.newplant.co.za/

${ }^{3}$ SNTC. Swaziland's flora database. Retrieved May 31, 2011, from http://www.sntc.org.sz/flora/index.asp

${ }^{4}$ Plants for a Future. Retrieved May 31, 2011, from http://www.pfaf.org/user/plantsearch.aspx

${ }^{5}$ Wikipedia. Annona senegalensis. Retrieved May 31, 2011, from http://en.wikipedia.org/wiki/Annona_senegalensis

${ }^{6}$ PlantZAfrica.com. Retrieved May 31, 2011, from http://plantzafrica.com/

${ }^{7}$ Flora of Zimbabwe. Retrieved May 31, 2011, from http://www.zimbabweflora.co.zw/index.php

${ }^{8}$ Miner, L. J. (2011). Coccina quinqueloba. Retrieved May 31, 2011, from

http://plantilus.com/plantdb/CoccQuin/

${ }^{9}$ OLAC Language Resource Catalog. Retrieved May 31, 2011, from

http://dla.library.upenn.edu/dla/olac/record.html?id=www_mpi_nl_1839/00-0000-0000-0005-6937-9

${ }_{10}$ www.kyffhuser.co.za/Plants1/Coccinia_rehmannii/Index.htm

${ }^{11}$ Wikipedia. Dactyloctemium aegyptium. Retrieved May 31, 2011, from

http://en.wikipedia.org/wiki/Dactyloctenium_aegyptium

${ }^{12}$ Flora of Mozambique. Retrieved May 31, 2011, from http://mozambiqueflora.com/speciesdata/

${ }^{13}$ Being plants. Retrieved May 31, 2011, from http://beingplants.com/Tree-list.php

${ }^{14}$ Schmidt, E., M. Lotter, W. McCleland. (2002). Trees and shrubs of Mpumalanga and Kruger National

Park. Johannesburg, South Africa: Jacana.

${ }^{15}$ Diospyros scabrida. Retrieved May 31, 2011, from

http://ontariogardening.com/Knowledgebase/speciedetail.jsp?id=1458

${ }^{16}$ Wood, J. M., and M. S. Evans. (1970). Natal plants. Cramer, NY: Verlag von J. Cramer.

${ }^{17}$ Ficus sycomorus. Retrieved May 31, 2011, from http://en.wikipedia.org/wiki/Ficus_sycomorus

${ }_{18}^{18}$ Joyner, G. Governor's plum. Retrieved May 31, 2011, from http://www.quisqualis.com/18govpjoy.html

${ }^{19}$ JSTOR Plant Science. Entry for Inhambanella henriquesii. Retrieved May 31, 2011, from http://plants.jstor.org/flora/fz5401

${ }^{20}$ Kedrostis africana. Retrieved May 31, 2011, from

http://bigfootcollections.com/product_info.php?products_id=187\&osCsid=slnopnelja

${ }^{21}$ TopTropicals Plant Catelog. Retrieved May 31, 2011, from

http://toptropicals.com/catalog/uid/Kedrostis_nana.htm

${ }^{22}$ The mbunbu fruit. Retrieved May 31, 2011, from

http://www.naturalhub.com/natural_food_guide_fruits_uncommon_Landolphia_spp.htm

${ }^{23}$ Lantana camara. Retrieved May 31, 2011, from http://en.wikipedia.org/wiki/Lantana_camara

${ }^{24}$ Beautiful flowers in the garden. Retrieved May 31, 2001, from http://mygarden-

flowers.blogspot.com/2009/01/lantana-camara.html

${ }^{25}$ Kumbula Indigenous Nursery. Lantana rugosa. Retrieved May 31, 2011, from

http://kumbulanursery.co.za/plants/lantana-rugosa 
${ }^{26}$ Operation Wildflower. Maytenus undata. Retrieved May 31, 2011, from http://operationwildflower.org.za

${ }^{27}$ Rumex. Retrieved May 31, 2011, from http://en.wikipedia.org/wiki/Rumex

${ }^{28}$ Flora of China. Retrieved May 31, 2011, from

http://www.efloras.org/florataxon.aspx?flora_id=2\&taxon_id=242444340

${ }^{29}$ Poisonous plants of Georgia. Retrieved May 31, 2011, from

http://plantbio.uga.edu/PPG/Plant\%20Summary\%20Pages/senna_occidentalis.htm

${ }^{30}$ Sonchus. Retrieved May 31, 2011, from http://en.wikipedia.org/wiki/Sonchus

${ }^{31}$ Ximenia Americana. Retrieved May 31, 2011, from http://en.wikipedia.org/wiki/Ximenia_americana

${ }^{32}$ Ziziphus mauritiana. Retrieved May 31, 2011, from http://en.wikipedia.org/wiki/Ziziphus_mauritiana 


\section{APPENDIX C: NUTRIENT PROFILES OF WILD EDIBLE PLANTS}

Nutrients per $100 \mathrm{~g}$ leafy green vegetables ${ }^{1}$

\begin{tabular}{|c|c|c|c|c|c|c|c|c|c|c|c|c|c|c|c|c|c|c|c|}
\hline Plant & 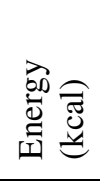 & $\begin{array}{l}\text { ब0, } \\
. \Xi \\
0 \\
0 \\
0 \\
0\end{array}$ & 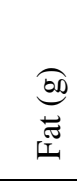 & $\begin{array}{l}\text { क्षि } \\
\dot{\bar{D}} \\
\stackrel{0}{1}\end{array}$ & 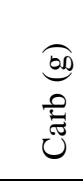 & 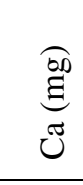 & $\begin{array}{l}\stackrel{000}{\Xi} \\
\sum_{\Sigma}^{\infty 00}\end{array}$ & 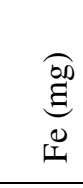 & $\begin{array}{l}\overparen{O D} \\
\Xi \\
\tilde{z} \\
Z\end{array}$ & 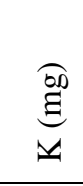 & $\begin{array}{l}\stackrel{O D D}{\Xi} \\
\Xi \\
\Xi\end{array}$ & 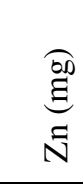 & $\underset{0}{\stackrel{000}{\Xi}}$ & 龸 & 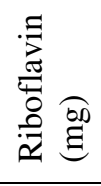 & $\stackrel{\Xi}{\stackrel{\Xi}{\Xi}} \stackrel{000}{\Xi}$ & 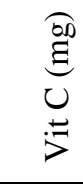 & 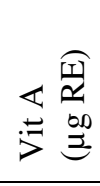 & 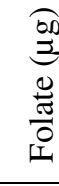 \\
\hline Amaranth $^{2}$ & 29 & 3.0 & 0.2 & 1.95 & 4.4 & 280 & 114 & 6.59 & 14.2 & 588 & 0.21 & 0.72 & 65.6 & 0.03 & 0.11 & 0.65 & 83.6 & 139 & 57 \\
\hline Asystasia gangetica $^{3}$ & 50 & 3 & 0.5 & 1.63 & 8.3 & 385 & 144 & 3.15 & 140 & & 0.6 & 1.05 & 122 & & & & & & \\
\hline Bidens pilosa & 46 & 3.4 & 0.4 & 1.7 & 7.1 & 175 & 135 & 6.01 & 7.4 & 462 & 0.58 & 0.91 & 68.1 & 0.08 & 0.18 & 0.71 & 22.9 & 983 & \\
\hline Centella asiatiea & 58 & 3.2 & 1.3 & 2.4 & 8.3 & 213 & 115 & 13.1 & 1.9 & 338 & 0.37 & 2.04 & 34 & 0.05 & 0.21 & 0.75 & 23 & 733 & \\
\hline Ceratotheca triloba ${ }^{3}$ & 62 & 2 & 2.1 & 2.07 & 8.3 & 106 & 64 & 2.85 & 17.3 & & 0.45 & 0.45 & 33.5 & & & & & & \\
\hline Chenopodium album & 38 & 4.4 & 0.3 & 1.6 & 4.3 & 226 & 155 & 6.09 & 13.3 & 601 & 0.4 & 1.36 & 60.8 & 0.03 & 0.31 & 0.58 & 31.4 & 915 & \\
\hline Chenopodium murale & 43 & 4.8 & 0.4 & 2.4 & 5.2 & 151 & 218 & 9.3 & 124 & 488 & 0.38 & 1.8 & 88.2 & 0.03 & 0.16 & 0.49 & & & \\
\hline Cleome gynandra & 42 & 4.6 & 0.9 & 2.5 & 3.8 & 189 & 76 & 2.64 & 19.3 & 478 & 0.42 & 0.76 & 12 & 0.1 & 0.12 & 1.29 & & & \\
\hline Cleome monophylla ${ }^{3}$ & 39 & 5 & 0.7 & 2.14 & 3.4 & 384 & 45 & 2.88 & 3 & & 0.24 & 0.6 & 94.1 & & & & & & \\
\hline Conyza bonariensis & 56 & 3.2 & 0.2 & 3.3 & 10.4 & 347 & 109 & 16.4 & 102 & 704 & 0.72 & 2.65 & 47 & 0.08 & 0.21 & 1 & 17 & 933 & \\
\hline Cucumis africanus & 21 & 1.3 & 0.3 & 1.2 & 3.4 & 216 & 175 & 12.1 & 11.3 & 109 & 0.17 & 0.31 & 11.1 & 0.02 & 0.11 & 0.34 & 80.5 & & \\
\hline Cucumis metuliferus $^{3}$ & 43 & 4 & 0.7 & 2.42 & 5.6 & 387 & 133 & 2.6 & 41.2 & & 0.39 & 1.43 & 56.4 & & & & & & \\
\hline Emex australis $^{3}$ & 36 & 5 & 0.6 & 1.57 & 2.7 & 18 & 112 & 1.65 & 36.5 & & 0.11 & 2.2 & 31.9 & & & & & & \\
\hline Galinsoga pariflora & 37 & 3.2 & 0.4 & 1.1 & 5.2 & 284 & 60 & 5.3 & 2.3 & 351 & 0.33 & 1.32 & 58 & 0.08 & 0.21 & 1.21 & 12 & 767 & \\
\hline Justicia flava $^{3}$ & 51 & 3 & 0.4 & 1.39 & 8.8 & 332 & 225 & 2.56 & 93 & & 0.96 & 1.76 & 46.7 & & & & & & \\
\hline Momordica balsamina $^{3}$ & 53 & 5 & 0.5 & 2.75 & 6.8 & 403 & 92 & 3.45 & 56.4 & & 0.45 & 1.8 & 53.4 & & & & & & \\
\hline Oxygonum sinuatum ${ }^{3}$ & 25 & 3 & 0.5 & 1.68 & 2.9 & 118 & 42 & 3.12 & 117 & & 0.32 & 0.56 & 37.8 & & & & & & \\
\hline Physalis viscose & 54 & 4.9 & 0.6 & 1.7 & 7.3 & 151 & 110 & 21.6 & 18.3 & 748 & 0.26 & 1.3 & 65.6 & 0.12 & 0.25 & 1.33 & & & \\
\hline
\end{tabular}




\begin{tabular}{|c|c|c|c|c|c|c|c|c|c|c|c|c|c|c|c|c|c|c|c|}
\hline Plant & 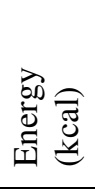 & 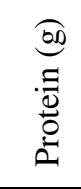 & 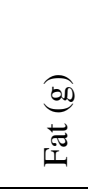 & 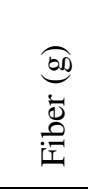 & $\begin{array}{l}\text { क्रि } \\
\text { : } \\
\text { Uే }\end{array}$ & 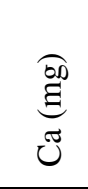 & $\begin{array}{l}\underset{D 0}{\Xi} \\
\underbrace{\infty} \\
\sum\end{array}$ & 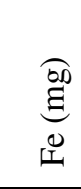 & 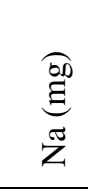 & $\begin{array}{l}\stackrel{\partial 0}{\Delta D} \\
\stackrel{\Xi}{y}\end{array}$ & $\begin{array}{l}\stackrel{00}{G} \\
\vec{\Xi}\end{array}$ & $\begin{array}{l}\text { OD } \\
\text { 齐 } \\
\text { N }\end{array}$ & $\begin{array}{l}\stackrel{\partial 0}{a} \\
\stackrel{\Xi}{a}\end{array}$ & 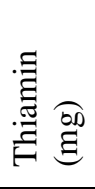 & 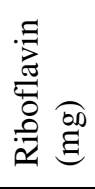 & 胥 & $\begin{array}{l}\underset{b 0}{\Xi} \\
\stackrel{\Xi}{=}\end{array}$ & 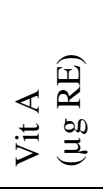 & $\begin{array}{l}\text { O00 } \\
3 \\
0 \\
0 \\
\frac{0}{0} \\
0 \\
0\end{array}$ \\
\hline Portulaca oleracea ${ }^{2}$ & 18 & 1.5 & 0.2 & & 3.6 & 78 & 67 & 0.77 & 44 & 488 & 0.11 & 0.17 & 37 & 0.03 & 0.09 & 0.46 & 10.5 & 93 & 9 \\
\hline Potrulacarea afra & 51 & 1.4 & 0.04 & 1.9 & 10.3 & 80 & 174 & 1.09 & 2.7 & 317 & 0.28 & 0.35 & 2 & 0.09 & 0.05 & 0.35 & 40.6 & & \\
\hline Raphanus raphanistrum & 34 & 3.7 & 0.3 & 1.4 & 4.1 & 285 & 99 & 9.51 & 6.8 & 530 & 0.18 & 1.36 & 54.6 & 0.07 & 0.14 & 0.62 & 11 & 300 & \\
\hline Rorippa nudiuseula & 47 & 4.9 & 0.3 & 3 & 6.2 & 366 & 54 & 12.5 & 4.6 & 369 & 0.21 & 1.03 & 51 & 0.1 & 0.23 & 2.04 & & & \\
\hline Rumex lancealatus & 58 & 4.6 & 0.7 & 1.8 & 8.2 & 111 & 85 & 9.7 & 14 & 693 & 0.13 & 2.4 & 74.1 & 0.12 & 0.17 & 1.55 & & & \\
\hline Senna occidentalis ${ }^{3}$ & 84 & 7 & 2.2 & 2.58 & 9.4 & 513 & 196 & 2.53 & 80 & & 0.46 & 2.07 & 95.9 & & & & & & \\
\hline Solanum nigrum & 46 & 5.3 & 0.4 & 2.8 & 5.3 & 278 & 84 & 8.54 & 10 & 421 & 0.36 & 1.16 & 105 & 0.1 & 0.32 & 1.07 & 22.3 & 1063 & \\
\hline Sonchus asper & 33 & 2.3 & 0.5 & 1.6 & 4.7 & 198 & 57 & 14.9 & 98 & 363 & 0.39 & 0.8 & 31.6 & 0.04 & 0.13 & 0.51 & & & \\
\hline Sonchus oleraceus & 25 & 2.2 & 0.5 & 1.5 & 2.9 & 193 & 51 & 7.1 & 70 & 371 & 0.25 & 0.9 & 40.6 & 0.03 & 0.11 & 0.38 & 25 & & \\
\hline Sonchus wilmsii & 34 & 2.8 & 0.4 & 1.1 & 4.9 & 188 & 90 & 1.4 & 5.3 & 500 & 0.67 & 0.19 & 73.2 & & & & 33.7 & & \\
\hline Stellaria media & 32 & 2.5 & 0.4 & 1.6 & 4.6 & 119 & 86 & 8.4 & 142 & 275 & 0.36 & 1.21 & 56 & 0.03 & & 0.51 & 1.3 & & \\
\hline Tylosema fassoglense & 107 & 6.4 & 2.9 & 3.3 & 13.6 & 61 & 46 & 0.49 & 0.83 & 317 & 0.83 & 0.81 & 111 & 0.03 & 0.1 & 0.9 & 39 & & \\
\hline Urtica urens $^{2}$ & 42 & 2.7 & 0.1 & 6.9 & 7.49 & 481 & 57 & 1.64 & 4 & 334 & 0.08 & 0.34 & 71 & 0.01 & 0.16 & 0.39 & & 101 & 14 \\
\hline Wahlenbergia undulata $^{3}$ & 75 & 5 & 0.3 & 1.33 & 12.8 & 261 & 39 & 3.8 & 75 & & 0.4 & 8.2 & 61.6 & & & & & & \\
\hline
\end{tabular}


Nutrient profiles per $100 \mathrm{~g}$ fruit $^{1}$

\begin{tabular}{|c|c|c|c|c|c|c|c|c|c|c|c|c|c|c|c|c|c|c|}
\hline Plant & 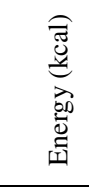 & 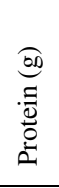 & 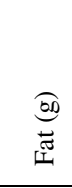 & 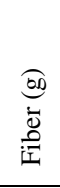 & 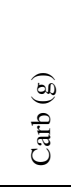 & $\begin{array}{l}\underset{00}{\Xi} \\
\text { Uే } \\
\text { Un }\end{array}$ & $\begin{array}{l}\stackrel{00}{80} \\
\stackrel{00}{E} \\
\sum\end{array}$ & 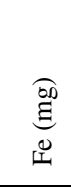 & $\begin{array}{l}\text { OD } \\
\text { हु } \\
\tilde{Z}\end{array}$ & 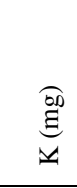 & $\begin{array}{l}\text { OD } \\
\stackrel{\Xi}{\Xi} \\
\Xi\end{array}$ & 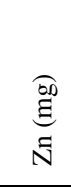 & $\begin{array}{l}\text { OD } \\
\text { E } \\
2\end{array}$ & 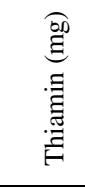 & 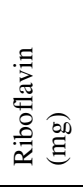 & 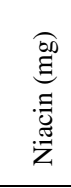 & $\begin{array}{l}\stackrel{00}{E} \\
\stackrel{\Xi}{U} \\
\stackrel{\Rightarrow}{\Rightarrow}\end{array}$ & 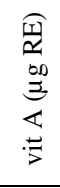 \\
\hline Acanthosicyos naudinianus & 26.5 & 1.3 & 0.2 & 2.1 & 4.8 & 21.2 & 23.6 & 0.52 & 1.53 & 270 & 0.12 & 0.24 & 25.1 & 0.09 & 0.03 & 0.98 & 34.9 & \\
\hline Acanthosicyos naudinianus & 26.5 & 1.3 & 0.2 & 2.1 & 4.8 & 21.2 & 23.6 & 0.52 & 1.53 & 270 & 0.12 & 0.24 & 25.1 & 0.09 & 0.03 & 0.98 & 34.9 & \\
\hline Allophylus decipiens & 96.7 & 2.4 & 0.4 & 2.1 & 20.8 & 25.1 & 26.3 & 1.48 & 15.2 & 349 & 0.3 & 0.6 & 34 & & & & 15.8 & \\
\hline Annona senegalensis & 78.6 & 1.7 & 1.5 & 3.9 & 14.5 & 41.6 & 83.8 & 0.74 & 1.31 & 465 & 0.21 & 0.26 & 175 & & 0.14 & 0.82 & 18.1 & \\
\hline Berchemia zeyheri & 88.4 & 1.1 & 0.1 & 0.7 & 20.7 & 75.8 & 39.2 & 1.02 & 1.3 & 313 & 0.24 & 0.17 & 25 & 0.09 & 0.11 & 0.27 & 6.5 & 17 \\
\hline Carissa bispinosa & 69.7 & 0.7 & 1.2 & 1.8 & 14 & 20.6 & 19.8 & 0.81 & 10.3 & 261 & 0.23 & 0.43 & 25.9 & 0.05 & 0.08 & 0.32 & 10.6 & \\
\hline Carissa macrocarpa & 77.8 & 0.5 & 1.1 & 1.6 & 16.4 & 22.6 & 19.5 & 0.56 & 1.58 & 298 & 0.21 & & 26.2 & 0.08 & 0.08 & 0.31 & 52.4 & \\
\hline Cassine piragua & 49.0 & 1.1 & 0.8 & 2 & 9.3 & 66.3 & 48.6 & 0.99 & 45.5 & 250 & 0.29 & 0.16 & 22.4 & 0.01 & 0.07 & 0.88 & & \\
\hline Citrullus lanatus & 14.3 & 0.4 & 0.04 & 1.2 & 3.1 & 31.6 & 16 & 0.3 & 2.1 & 267 & 0.27 & 0.09 & 5.1 & 0.06 & 0.01 & 0.34 & 9.2 & 75 \\
\hline Coccinia adoensis & 26.7 & 1.8 & 1 & 2.1 & 2.6 & 28.4 & 28.1 & 0.61 & 0.52 & 269 & 0.11 & 0.17 & 4.1 & & & & 19.2 & \\
\hline Coccinia quinqueloba & 34.6 & 1.8 & 1.3 & 1.9 & 3.9 & 21 & 20.8 & 0.21 & 2.48 & 259 & 0.18 & 0.15 & 36.2 & & & & 9 & \\
\hline Coccinia rehmannii & 35.8 & 2 & 1 & 2.2 & 4.7 & 66.8 & 30.6 & 0.49 & 3.77 & 292 & 0.12 & 0.46 & 35.8 & 0.05 & 0.04 & 0.79 & 3.5 & 115 \\
\hline Cucumis africanus & 38.9 & 2.8 & 1.6 & 2.9 & 3.3 & 13.1 & 29.2 & 1.1 & 1.1 & 439 & 0.22 & 0.37 & 20.2 & 0.2 & 0.03 & 0.84 & 12.8 & \\
\hline Cucumis metuliferus & 32.0 & 1.1 & 0.7 & 1.1 & 5.2 & 11.9 & 22.3 & 0.53 & 2.08 & 319 & 0.11 & 0.25 & 25.5 & 0.04 & 0.02 & 0.55 & 18.6 & \\
\hline Dialium schlechteri & 336.2 & 3.4 & 0.5 & 5 & 79.3 & 51.6 & 75.7 & 4.27 & 40.5 & 1598 & 1.63 & 1.16 & 164 & 0.43 & 0.07 & 2.01 & 7.8 & \\
\hline Diospyros lycioides & 70.7 & 0.9 & 0.1 & 3.5 & 16.5 & 66.8 & 39.7 & 1.04 & 16.3 & 271 & 0.23 & 0.3 & 13.7 & 0.11 & 0.09 & 0.17 & 45.2 & \\
\hline Diospyros scabrida & 131.8 & 1.8 & 0.2 & 4.2 & 30.6 & 162 & 24.7 & 2.89 & 14.8 & 496 & 0.44 & 0.56 & & & & & 97.4 & \\
\hline Ehretia rigida & 51.3 & 1.7 & 0.3 & 0.7 & 10.4 & 30.5 & 27.8 & 0.89 & 2.5 & 547 & 0.17 & 0.22 & & & & & 6.9 & \\
\hline Ekebergia capensis & 88.4 & 1.4 & 0.6 & 2.5 & 19.3 & 64.7 & 52.3 & 2.4 & 18 & 366 & 1.7 & 0.55 & 87.9 & 0.04 & 0.02 & 1.74 & 1 & \\
\hline Euclea crispa & & & & & & 203 & 75.9 & 2.07 & 3.51 & 92.9 & 0.21 & 0.24 & 68 & & & & & \\
\hline Eugenia albanensis & 43.2 & 0.8 & 0.3 & 3 & 9.3 & 31 & 12 & 0.48 & 32.3 & 197 & 0.05 & 0.09 & 10 & 0.007 & 0.006 & 0.35 & 24.4 & 0 \\
\hline Eugenia capensis & 118.4 & 0.9 & 0.4 & 1.4 & 27.7 & & 26.7 & 1.67 & 66.5 & 209 & 0.14 & 0.04 & 31.8 & 0.11 & 0.03 & 0.39 & 107 & \\
\hline Ficus abulilifolia & 49.0 & 0.7 & 0.9 & 3 & 9.5 & 85.8 & 37 & 0.12 & 5.85 & 270 & 0.09 & 0.12 & 28 & 0.04 & 0.07 & 0.23 & 17 & \\
\hline
\end{tabular}




\begin{tabular}{|c|c|c|c|c|c|c|c|c|c|c|c|c|c|c|c|c|c|c|}
\hline Plant & 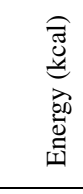 & 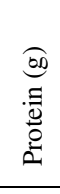 & 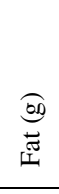 & 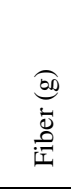 & 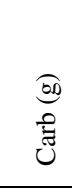 & $\underbrace{\stackrel{00}{E}}_{\tilde{U}}$ & $\begin{array}{l}\stackrel{O 00}{G} \\
\Xi_{00}^{\infty}\end{array}$ & 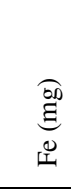 & $\begin{array}{l}\text { OD } \\
\text { 苟 } \\
\tilde{Z}\end{array}$ & 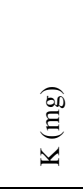 & $\begin{array}{l}\text { OD } \\
\Xi \\
\Xi \\
\Xi\end{array}$ & $\begin{array}{l}\text { OD } \\
\text { ह్ } \\
\text { సี }\end{array}$ & $\begin{array}{l}\widehat{O D} \\
\Xi \\
\Xi\end{array}$ & 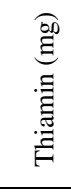 & 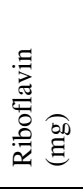 & 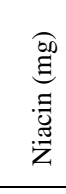 & 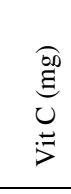 & 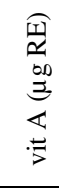 \\
\hline Ficus ingens & 60.9 & 1.6 & 1.1 & 9.7 & 11.1 & 118 & 56.9 & 1.96 & 1.61 & 415 & 0.31 & 0.76 & 44.9 & 0.04 & 0.1 & 0.5 & 7.6 & \\
\hline Ficus sur & 30.8 & 1.1 & 0.4 & 4.5 & 5.7 & 77.3 & 35.6 & 0.67 & 3.48 & 392 & 0.17 & 0.35 & 28.3 & 0.02 & 0.04 & 0.97 & 12 & \\
\hline Flacourtia indica & 32.7 & 0.9 & 1 & 20.7 & 5 & 48.1 & 27.3 & 1.21 & 4.6 & 188 & 0.36 & 0.4 & 16.2 & 0.03 & 0.06 & 0.24 & 5.4 & \\
\hline Garcinia livingstonei & 61.6 & 0.8 & 0.3 & 0.7 & 13.9 & 4.79 & 12.1 & 0.28 & 6.92 & 134 & 0.07 & 0.19 & 20.3 & & 0.05 & 0.4 & 5.4 & \\
\hline Harpoehylium caffrum & 41.1 & 0.7 & 0.2 & 1.7 & 9.1 & 47 & 23.7 & 0.6 & 5.73 & 254 & 0.14 & 0.14 & 13.3 & 0.12 & & & 70.7 & \\
\hline Kedrostis hirtella & 25.1 & 1.5 & 0.3 & 1.1 & 4.1 & 2.1 & 18 & 0.6 & 2.5 & 286 & 0.05 & 0.2 & 30.2 & 0.04 & 0.05 & 0.85 & & 23 \\
\hline Landolphia kirkii & 94.6 & 0.6 & 0.6 & 0.5 & 21.6 & 2.38 & 9 & 0.56 & 6.3 & 193 & 0.1 & 0.11 & 11 & 0.04 & 0.02 & 0.66 & 10.3 & \\
\hline Lantana rugosa & 121.1 & 2.9 & 3.4 & 3.8 & 19.6 & 48.1 & 126 & 18.9 & & 597 & 1.13 & 0.69 & 140 & & & & 5.1 & \\
\hline Manilkara discolor & 112.2 & 2.1 & 1.9 & 2.1 & 21.6 & 81.9 & 26.5 & 0.75 & 4.97 & 474 & 0.13 & 0.25 & 23.6 & 0.04 & 0.04 & 0.35 & 12.4 & 0 \\
\hline Mimusops obovata & 102.2 & 1.9 & 0.3 & 3 & 22.9 & 43.9 & 51.5 & 0.88 & 51.6 & 489 & 0.39 & 0.21 & 26 & & & & 60 & \\
\hline Mimusops zeyheri & 115.6 & 1.2 & 0.6 & 3.9 & 26.3 & 40.4 & 22.1 & 0.68 & 10.5 & 392 & 0.15 & 0.16 & 15.8 & & 0.01 & 0.36 & 28.6 & \\
\hline Momordica balsamina & 29.4 & 2 & 0.1 & 1.8 & 5.1 & 35.9 & 41.2 & 2.61 & 3.25 & 533 & 0.2 & 1 & 35.8 & 0.04 & 0.06 & 0.55 & 0.5 & \\
\hline Physalis peruviana & 73.1 & 2.3 & 0.9 & 3.6 & 13.9 & 10.5 & 34.8 & 2.37 & 2.98 & 496 & 0.36 & 0.38 & 61.5 & 0.24 & 0.15 & 1.68 & 42 & 400 \\
\hline Podocarpus falcatus & 85.3 & 3 & 0.3 & 5.2 & 17.6 & 46 & 20.1 & 1.6 & 11.5 & 460 & 0.98 & 0.2 & 10.3 & 0.04 & & 1.13 & & \\
\hline Rapanea melanophloeos & 74.0 & 1.5 & 2.2 & 1.6 & 12 & 48.2 & 19.9 & 2.07 & 71.7 & 239 & 0.08 & 0.17 & 12 & & & & 12.2 & \\
\hline Rhoicissus digitata & 59.9 & 0.9 & 0.1 & 2 & 13.8 & 71.1 & 17.9 & 0.92 & 8.14 & 568 & 0.11 & 0.35 & 12.5 & 0.04 & 0.1 & 1 & 17 & \\
\hline Salacia kraussii & 61.1 & 1.1 & 0.3 & 0.7 & 13.5 & 15 & 25.5 & 0.62 & 8.89 & 203 & 0.39 & 0.17 & 18.5 & 0.01 & 0.08 & 0.81 & 10.7 & \\
\hline Sclerocarya birrea & 53.7 & 0.5 & 0.4 & 1.2 & 12 & 20.1 & 25.3 & 0.5 & 2.24 & 317 & 0.07 & 0.1 & & 0.03 & 0.02 & 0.27 & 194 & \\
\hline Sideroxylon inerme & 126.3 & 4.3 & 4.4 & 1.5 & 17.3 & 46.4 & 41.7 & 1.18 & & 482 & 0.1 & 0.2 & 17 & 0.06 & 0.09 & 0.55 & 14.8 & \\
\hline Syzygium cordatum & 48.7 & 0.6 & 0.2 & 1.5 & 11.1 & 31.9 & 29.8 & 1.43 & 8.16 & 222 & 0.18 & 0.2 & 14.2 & 0.03 & 0.31 & 0.46 & 11.6 & \\
\hline Ximenia Americana & 132.8 & 2.8 & 0.8 & 1.2 & 28.5 & 7.58 & 31.1 & 1.27 & 3.33 & 718 & 0.28 & 0.68 & 34.2 & & & & 69.7 & 113 \\
\hline Ximenia caffra & 89.3 & 1.9 & 1.5 & 0.9 & 17 & 8.17 & 19 & 0.49 & 1.25 & 558 & 0 & 0.29 & 35.4 & 0.03 & 0.02 & 0.48 & 68.2 & 148 \\
\hline Zizihus mauritiana & 286.1 & 3.2 & 0.6 & 2.4 & 66.8 & 157 & 58.5 & 0.73 & 4.01 & 1078 & 0.32 & 0.39 & 101 & 0.05 & 0.08 & 1.96 & & \\
\hline Zizihus mucronata & 157.4 & 3.8 & 0.5 & 2.1 & 34.4 & 129 & 58.3 & 0.95 & 5.05 & 726 & 0.86 & 0.52 & 51.4 & 0.06 & 0.05 & 0.71 & 42.6 & \\
\hline
\end{tabular}


Nutrients per $100 \mathrm{~g}$ of roots, bulbs, and tubers ${ }^{1}$

\begin{tabular}{|c|c|c|c|c|c|c|c|c|c|c|c|c|c|c|c|c|c|}
\hline Plant & 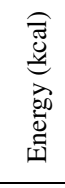 & 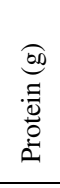 & 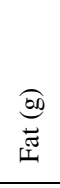 & 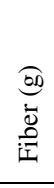 & $\begin{array}{l}\text { क्रि } \\
\text { 苞 } \\
\text { Un }\end{array}$ & $\underbrace{\stackrel{\sigma 00}{\Xi}}_{\tilde{U}}$ & 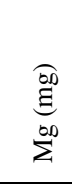 & 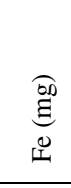 & 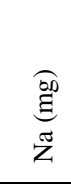 & $\begin{array}{l}\underset{\partial 0}{E} \\
\stackrel{\Xi}{E}\end{array}$ & $\begin{array}{l}\text { OD } \\
\Xi \\
\Xi\end{array}$ & $\begin{array}{l}\underset{\text { DD }}{\text { E }} \\
\text { Nี }\end{array}$ & $\begin{array}{l}\text { ODD } \\
\text { हू }\end{array}$ & 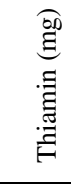 & 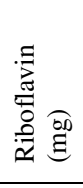 & 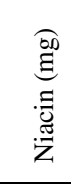 & 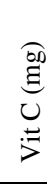 \\
\hline Boscia albitrunca & 107 & 6.5 & 0.2 & 3.6 & 19.8 & 63.6 & 75.8 & 0.38 & 37.2 & 504 & 0.08 & 0.78 & 14.4 & 0.02 & 0.03 & 0.24 & 6.6 \\
\hline Coccinia adoensis & 69 & 1.1 & 0.1 & 0.6 & 15.9 & 43.5 & 29.7 & 0.36 & 0.7 & 420 & 0.06 & 0.4 & 38.8 & 0.05 & 0.02 & 0.77 & 1.3 \\
\hline Coccinia rehmannii & 34 & 1.5 & 0.2 & 1.2 & 6.5 & 201 & 37.2 & 0.48 & 10.3 & 192 & 0.22 & 0.92 & 35.2 & 0.02 & 0.03 & 0.44 & 4.1 \\
\hline Cyperus esculentus & 82 & 0.9 & 0.1 & 1.1 & 19.2 & 236 & 75.5 & 4.2 & 27.7 & 218 & 0.28 & 0.61 & 32.4 & 0.02 & & 0.23 & 21 \\
\hline Cyperus rotundus & 151 & 5.1 & 0.3 & 1.6 & 31.9 & 31.3 & 57.9 & & 7.0 & 273 & 0.5 & 1.29 & 133 & 0.15 & 0.06 & & 4.2 \\
\hline Cyphia sp. & 73 & 1.4 & 0.5 & 1.8 & 15.7 & 45.6 & 42.1 & 0.51 & 53.9 & 273 & 0.16 & 0.57 & 62.6 & 0.04 & 0.02 & 0.81 & 6.2 \\
\hline Kedrostis hirtella & 77 & 3.3 & 0.1 & 1.4 & 15.6 & 122 & 54.9 & 1.1 & 4.9 & 384 & 0.06 & 0.59 & 57.1 & 0.06 & 0.02 & 1.15 & 4.5 \\
\hline Kedrostis nana & 16 & 0.2 & 0.1 & 0.9 & 3.5 & 118 & 68.9 & 0.6 & 12.7 & 248 & 0.04 & 0.12 & 9.65 & 0.01 & & 0.08 & \\
\hline Tylosema fassoglense & 57 & 1.6 & 0.5 & 4.4 & 11.4 & 54.2 & 18.3 & 0.26 & 2.2 & 183 & 0.4 & 0.5 & 13.7 & 0.04 & 0.005 & 0.02 & 6.5 \\
\hline
\end{tabular}


Nutrient profiles per $100 \mathrm{~g}$ seeds, nuts, and grains ${ }^{1}$

\begin{tabular}{|c|c|c|c|c|c|c|c|c|c|c|c|c|c|c|c|c|}
\hline Plant & 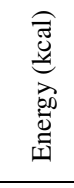 & 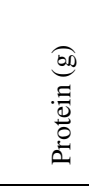 & 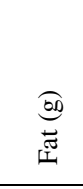 & 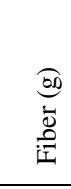 & 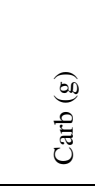 & $\underbrace{\overparen{\sigma}}_{\tilde{U}}$ & $\begin{array}{l}\text { OD } \\
\underbrace{\infty 0}_{00}\end{array}$ & & $\begin{array}{l}\text { ब0 } \\
\text { ह } \\
\tilde{Z}\end{array}$ & 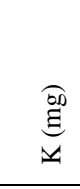 & 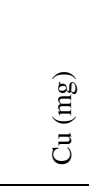 & $\begin{array}{l}\text { ब0 } \\
\text { 足 } \\
\text { N }\end{array}$ & $\begin{array}{l}\text { OD } \\
\text { E } \\
2\end{array}$ & 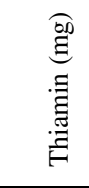 & 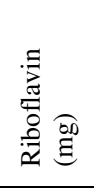 & 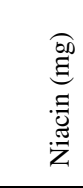 \\
\hline Amaranth $^{2}$ & 371 & 13.56 & 7.02 & 6.7 & 65.25 & 159 & 248 & 7.61 & 4 & 508 & 0.525 & 2.87 & 557 & 0.116 & 0.2 & 0.923 \\
\hline Citrullus lanatus & 304 & 17.9 & 20.2 & 41.8 & 12.5 & 54 & 209 & 6.55 & 5.67 & 433 & 1.14 & 3.4 & 474 & 0.59 & 0.27 & 2.45 \\
\hline Dactyloctenium aegyptium & 295 & 9.8 & 1.8 & 17 & 59.6 & 66.5 & 220 & 6.9 & 24.7 & 724 & 1.92 & 4.65 & 297 & 0.91 & 0.27 & 2.14 \\
\hline Eleusine coracanna & 340 & 6.2 & 1.5 & 2.9 & 75.1 & 29.6 & 137 & 3.07 & 3.4 & 490 & 0.67 & 1.82 & 223 & & & \\
\hline Lablab purpureus & 321 & 19.7 & 1 & 7.8 & 58.2 & 67.1 & 76.7 & 6 & 2.5 & 1040 & 0.58 & 2.49 & 368 & 0.59 & 0.17 & 1.77 \\
\hline Parinari capensis & 697 & 26.3 & 65.1 & 2.6 & 1 & 59.3 & 400 & 4.73 & 6.08 & 470 & 1.56 & 3.73 & 411 & 0.71 & 0.19 & 3.79 \\
\hline Sclerocarya birrea & 645 & 28.3 & 57.3 & 2.9 & 3.7 & 118 & 462 & 4.87 & 3.81 & 601 & 2.81 & 5.19 & & 0.42 & 0.12 & 0.72 \\
\hline Setaria italic & 347 & 14.3 & 4.8 & 8.1 & 61.3 & 21 & 148 & 3.07 & 3.95 & 410 & 1.3 & 3.5 & 397 & 1.05 & 0.17 & 0.59 \\
\hline Tylosema fassoglense & 348 & 22 & 14.2 & 18.2 & 32.9 & 101 & 133 & 1.72 & 0.85 & 651 & 0.7 & 2.24 & 362 & 0.13 & 0.08 & 1.22 \\
\hline
\end{tabular}

